\title{
WestVirginiaUniversity
}

THE RESEARCH REPOSITORY @ WVU

Graduate Theses, Dissertations, and Problem Reports

2020

\section{Light and Shadow in Kaija Saariaho's Maan Varjot}

Benjamin M. Cornelius-Bates

drericfritz@gmail.com

Follow this and additional works at: https://researchrepository.wvu.edu/etd

Part of the Composition Commons, and the Music Theory Commons

\section{Recommended Citation}

Cornelius-Bates, Benjamin M., "Light and Shadow in Kaija Saariaho's Maan Varjot" (2020). Graduate Theses, Dissertations, and Problem Reports. 7980.

https://researchrepository.wvu.edu/etd/7980

This Dissertation is protected by copyright and/or related rights. It has been brought to you by the The Research Repository @ WVU with permission from the rights-holder(s). You are free to use this Dissertation in any way that is permitted by the copyright and related rights legislation that applies to your use. For other uses you must obtain permission from the rights-holder(s) directly, unless additional rights are indicated by a Creative Commons license in the record and/ or on the work itself. This Dissertation has been accepted for inclusion in WVU Graduate Theses, Dissertations, and Problem Reports collection by an authorized administrator of The Research Repository @ WVU.

For more information, please contact researchrepository@mail.wvu.edu. 
Graduate Theses, Dissertations, and Problem Reports

2020

Light and Shadow in Kaija Saariaho's Maan Varjot

Benjamin M. Cornelius-Bates

Follow this and additional works at: https://researchrepository.wvu.edu/etd

Part of the Composition Commons, and the Music Theory Commons 
Light and Shadow in Kaija Saariaho's Maan Varjot

Benjamin Cornelius-Bates

\author{
Research Document submitted to the \\ School of Music \\ at West Virginia University \\ in partial fulfillment of the requirements \\ for the degree of
}
Doctor of Musical Arts
in
Music Composition

\author{
David Taddie, Ph.D., chair \\ Matthew Heap, Ph.D., research advisor \\ Lynn Hileman, D.M.A. \\ Travis Stimeling, Ph.D. \\ Beth Royall, M.M., M.LIS.
}
Morgantown, West Virginia 2020

Keywords: Kaija Saariaho, Maan Varjot

Copyright 2020 Benjamin Cornelius-Bates 


\begin{abstract}
Light and Shadow in Kaija Saariaho's Maan Varjot
\end{abstract}

Benjamin Cornelius-Bates

Kaija Saariaho's work Maan Varjot is a relatively new addition to a set of repertoire that includes the organ as a part of the orchestra. This commission from the Orchestre Symphonique de Montréal, Orchestre National de Lyon, Southbank Centre, and the Philharmonia Orchestra, was premiered in 2014 and features the organ as a timbral enhancement and contrast to the orchestra. The $52^{\text {nd }}$ Stanza from the poem Adonais, written by Percy Shelley and dedicated to John Keats, provide an important insight into the analysis and interpretation of the work. Two lines in particular are important: "The One remains, the many change and pass/Heaven's light forever shines, Earth's shadows fly." These lines imply two interacting elements, similar to how the organ and orchestra are orchestrated in conjunction and opposition to one another in Maan Varjot. This paper seeks to show how Saariaho manipulates the musical possibilities of the instruments, particularly those of the organ, in contrast and complement to the orchestra through the lens of the Shelley poem. 


\section{Table of Contents}

\section{Chapters}

I. Introduction to Maan Varjot and Kaija Saariaho ..................................................... 1

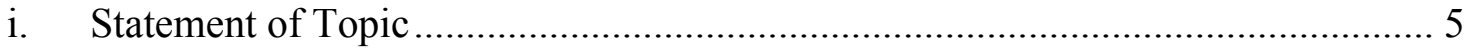

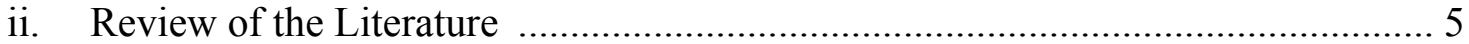

II. Setting the Scope: The Building Blocks and Limitations of Analyzing Maan Varjot Saariaho.

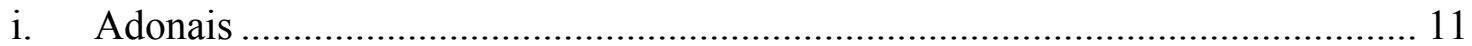

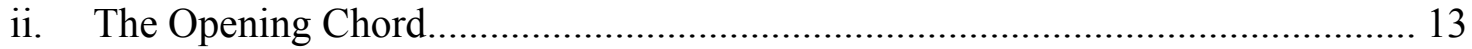

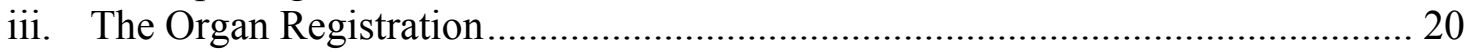

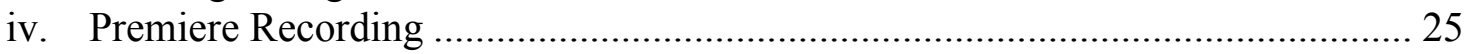

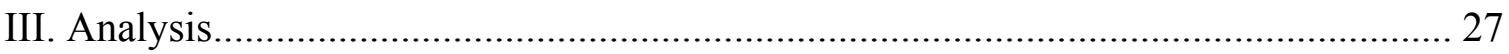

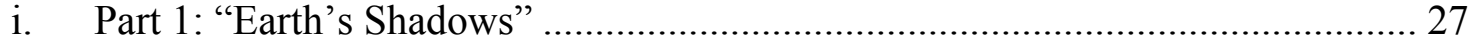

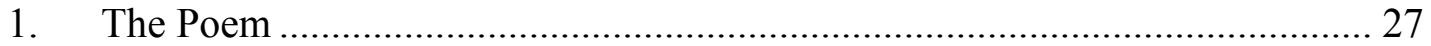

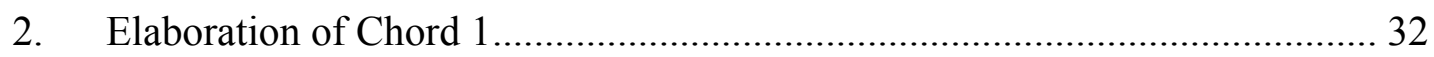

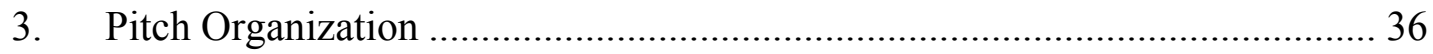

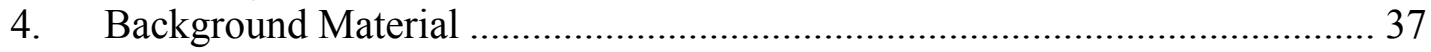

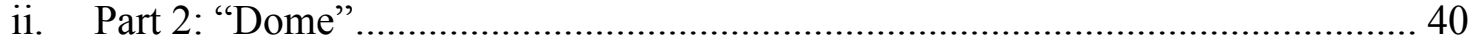

1. The Poem ............................................................................................ 40

2. The Chorale .............................................................................................. 41

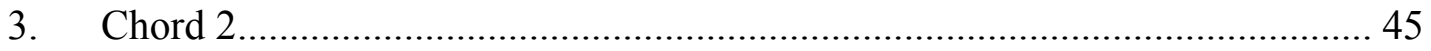

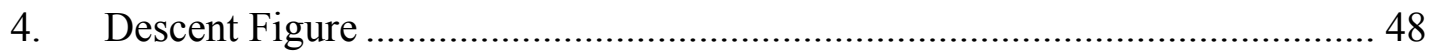

5. The Dome

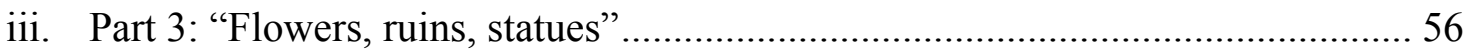

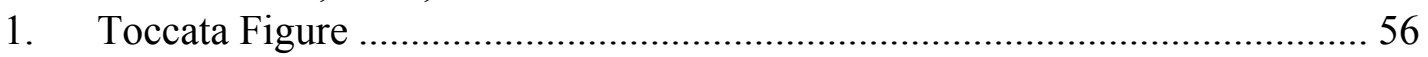

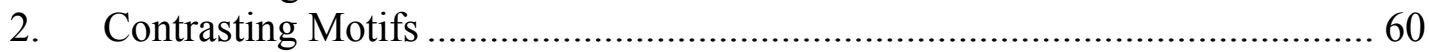

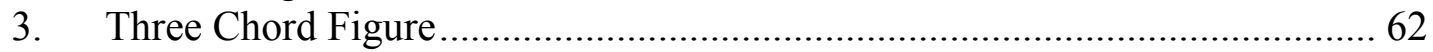

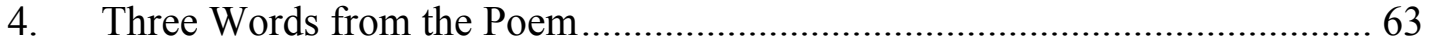

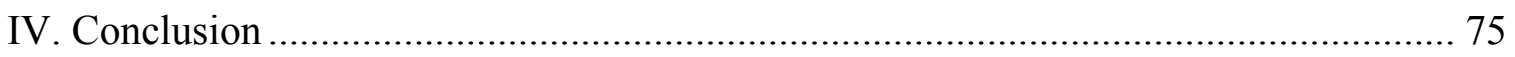

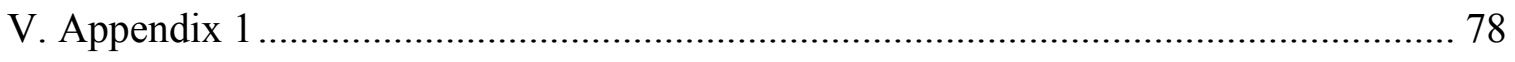

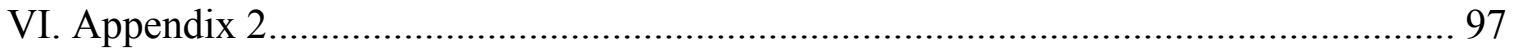

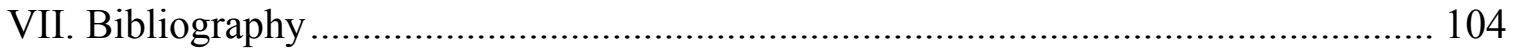


List of Charts and Musical Quotes

Example 1 - The Opening Chord (which will be called Chord 1) ................................. 14

Example 2 - Symmetry in Maan Varjot as a Whole ................................................... 17

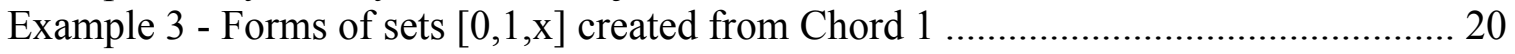

Example 4 - Total possible pitches based on the notation and organ registration........... 24

Example 5 - Perceptible pitches of Chord 1 ................................................................ 25

Example 6 - Foreground and background/light and shadow in "Earth's Shadows"......... 28

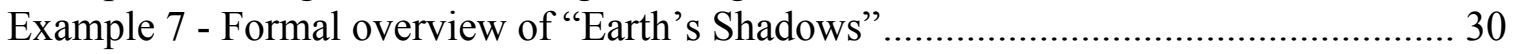

Example 8 - Various foreground motifs found in the B sections of "Earth's Shadows".. 32

Example 9 - Perceivable pitches in the Elaboration Chord ......................................... 33

Example 10 - The regularity of the Elaboration Chord pitch material in section A......... 34

Example 11 - General bass movement through "Earth's Shadows"............................... 36

Example 12 - B' background material in the organ solo part ......................................... 39

Example 13 - "Ein feste Burg," chorale written by Martin Luther................................ 42

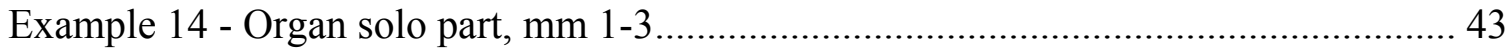

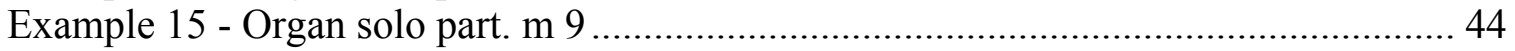

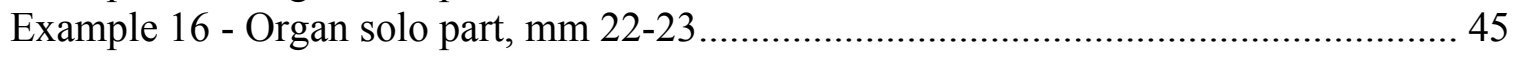

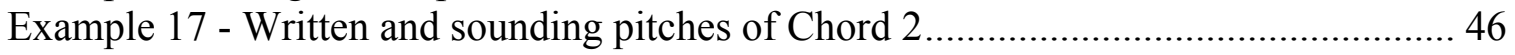

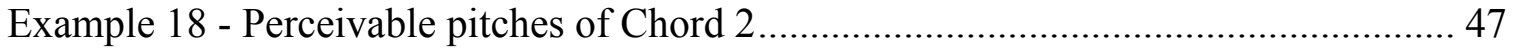

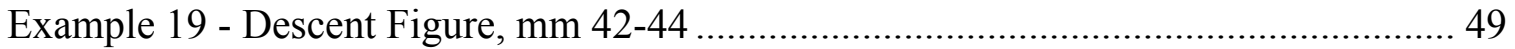

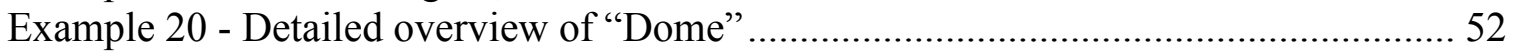

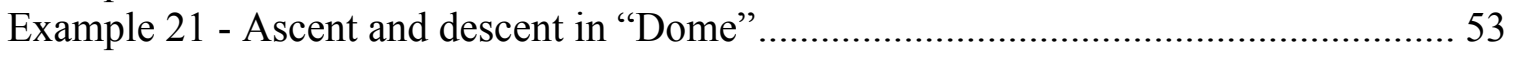

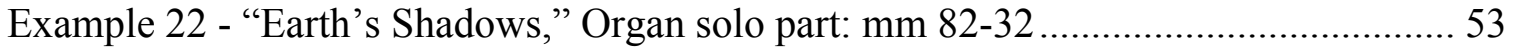

Example 23 - "Dome," organ and low brass, mm 39-41 ............................................ 54

Example 24 - Charles Marie Widor's Toccata from Fifth Organ Symphony.................. 57

Example 25 - Eugène Gigout's Toccata from 10 Pièces pour orgue ............................... 57

Example 26 - Charles Tournemire's Toccata from his Suite de morceaux ..................... 58

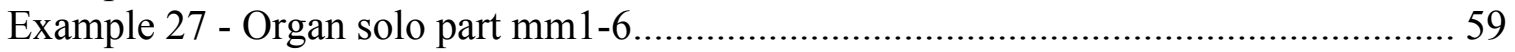

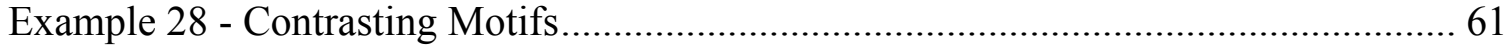

Example 29 - Vibraphone, $\mathrm{m} 2$ and organ solo part $\mathrm{m}$ 5, left hand doubled by marimba. 62

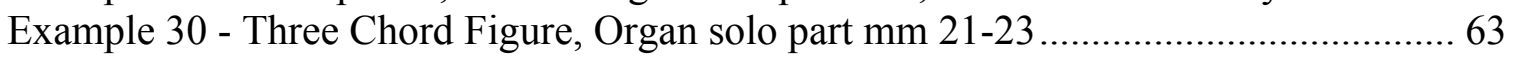

Example 31 - Tutti Toccata figure in the organ solo part, mm 105-106 ........................ 64

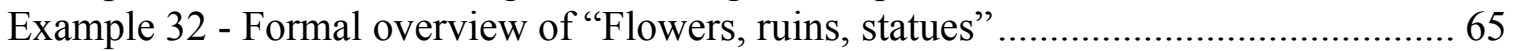

Example 33 - Decibel peaks and spectrogram of the recording for "Flowers, ruins,

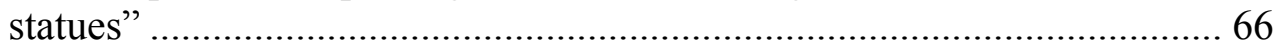

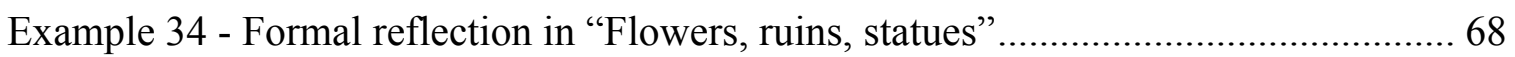

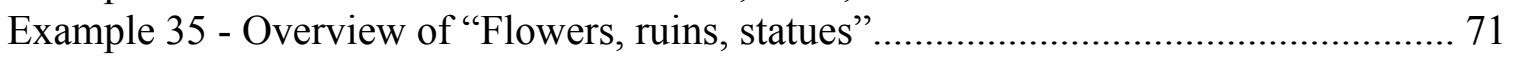

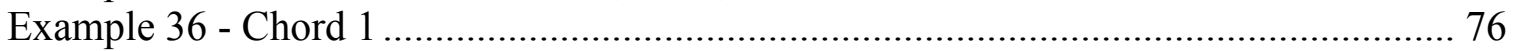

Example 37 - First example of the reverberation in the Maison Symphonique de Montréal in the third movement of Maan Varjot after the nearly tutti orchestra ...... 77

Example 38 - Second example of the reverberation in the Maison Symphonique de Montréal in the third movement of Maan Varjot after the full organ ....... 78

Example 39 - ReaVerbate settings to digitally approximate the acoustics of the concert

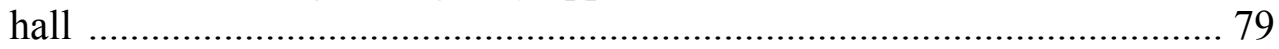


Example 40 - "I. Earth's Shadows," 0:00 - 0:05 (into the recording)............................ 81

Example 41 - "I. Earth's Shadows," 4:58-5:02, piccolo entrance .................................. 82

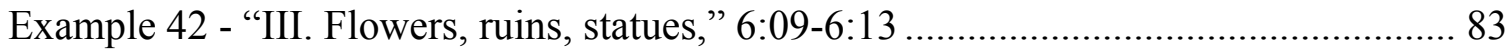

Example 43 - "III. Flowers, ruins, statues," 0:00-0:05, Toccata Figure .......................... 84

Example 44 - "III. Flowers, ruins, statues," 2:49-2:54, Tutti Toccata Figure ................ 85

Example 45 - Literal written pitch realization .......................................................... 86

Example 46 - Realization with the all of the pitches in the recommended registration .. 88

Example 47 - Third model built based on a combination of the notated pitches and the recommended registration ............................................................... 89

Example 48 - Comparisons of the spectrograms: A - Chord 1 from "Earth's Shadows opening," Example 40; B - Comparative Model from Example 47; C Chord 1 from "Earth's Shadows" ending, Example 41; D - Chord 1 from "Flowers, ruins, statues," Example 42

Example 49 - Spectrogram of the Elaboration Chord, 1:25-1:29 ................................ 92

Example 50 - Comparisons of the Elaboration Chord, A, and the Comparative Model, B

Example 51 - The Toccata Figure primarily in the organ at the beginning of "Flowers,

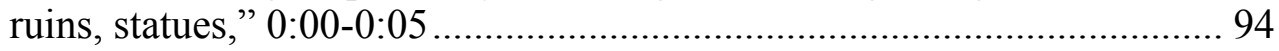

Example 52 - Example 52 - The Tutti Toccata Figure in the middle of "Flowers, ruins, statues" with most of the orchestra, 2:49-2:53

Example 53 - Chord 2 at the beginning of "Dome," A, and the Comparative Model, B, $0: 20-0: 25$ 96

Example 54 - Stop list from the organ at Maison Symphonique de Montréal Hall .... 102

Example 55 - Stop list from the organ at the Walt Disney Concert Hall 103 


\section{CHAPTER 1: Introduction to Maan Varjot and Kaija Saariaho}

From early in her career as a composer, Kaija Saariaho has shown an interest in dichotomies and dualities, particularly in what she describes as a sound/noise axis. The duality to her is between what she defines as pure sounds, such as a bell or the human voice, and noise, which includes breathing or sul ponticello on a string instrument. To her, in an abstract way, sound and noise can be a substitution for consonance and dissonance and this idea manifests itself in many ways in her works through form, timbre, and harmony. ${ }^{1}$ They are not just simply opposites; they are oppositions that she continuously explores in her works including Maan Varjot.

Born in Finland in 1952, her childhood was marked by solitude due to sensitivities and illness. Her childhood was also filled with freedom where she explored the forests and the countryside of Särkisalmi in Eastern Finland. ${ }^{2}$ Here she began to develop a relationship with naturally occurring sounds. She has reflected that her "...favorite activity was to walk in the forest after the rain, when the leaves of the trees were still wet. They reflected the bird song differently - the forest was like a great echoing hall."3 She studied on several instruments including the violin, piano, and guitar, but never felt comfortable as a performer. She attempted composing in her youth but found the results unsatisfying. She grew up with a love of the visual arts as well, something encouraged by her parents. The formative elements of nature, art, and sound

\footnotetext{
${ }^{1}$ Kaija Saariaho, "Timbre and Harmony: Interpolations of Timbral Structures," Contemporary Music Review 2, no.1 (1987): 94.

2 Pirrko Moisala. "Kaija Saariaho," Urbana and Chicago: University of Illinois Press, 2009: 2.

3 Ibid. 2.
} 
are key components in her upbringing that still greatly influence her compositional output today.

Before Saariaho became a full-time composition student, she explored other pursuits as a possible profession. She studied art at the Institute of Industrial Arts and Crafts, while she studied musicology, music theory and took private piano and organ at the Helsinki Conservatory. ${ }^{4}$ She strongly considered a career as an organist. ${ }^{5}$ At the time, she considered the organ her preferred instrument. ${ }^{6}$ She has also expressed her fondness for the repertoire and tradition found in the history of the organ with particular admiration of Johann Sebastian Bach's works and the improvisation tradition in France. ${ }^{7}$

Saariaho's ultimate desire though was to compose and was eventually admitted to the composition class of Paavo Heininen at the Sibelius Academy in 1976. He was highly demanding but also nurturing and helped Saariaho develop her own voice. A number of compositions at this time were written for voice. She was always drawn to texts, saying "texts just stay in me...texts bring another layer...and their whispering becomes more intense." ${ }^{8}$ None of the vocal compositions from this time are in her current catalogue but it is important to note that text plays an important role in the creation of her music.

Several of her classmates have also gained international success, including composer Magnus Lindberg and conductor Esa-Pekka Salonen, who was one of the

\footnotetext{
${ }^{4}$ Pirrko Moisala. "Kaija Saariaho," Urbana and Chicago: University of Illinois Press, 2009: 4 .

${ }^{5}$ Nadia Sirota, "Kaija Saariaho: Ears Open," Meet the Composer, Podcast. July 30, 2015, https://www.npr.org/podcasts/528124256/meet-the-composer.

${ }^{6}$ Clément Mao-Takacs, "A Conversation with Kaija Saariaho," Music \& Literature No. 5 (2014): 59.

${ }^{7}$ Ibid. 59 and "Esa-Pekka Salonen, Kaija Saariaho and Olivier Latry introduce Saariaho's Maan varjot." Jun 12, 2014, Youtube, https://www.youtube.com/watch?v=p4lfQy-ImhY

${ }^{8}$ Nadia Sirota, "Kaija Saariaho: Ears Open," Meet the Composer, Podcast. July 30, 2015, https://www.npr.org/podcasts/528124256/meet-the-composer.
} 
conductors of the premiere of Maan Varjot. Together along with several other students at the time, they formed the Open Ears! (Korvat auki!) club. ${ }^{9}$ They listened to modern works of the $20^{\text {th }}$ century and presented pieces to one another that contrasted the Sibeliuslike nationalistic style that pervaded Finland's compositional scene in the 1960s and 1970s. ${ }^{10}$

After graduating from the Sibelius Academy, she attended summer courses in Darmstadt, Germany where she studied with Brian Ferneyhough and Klaus Huber. She found their post-serialist aesthetics limiting and in conflict with her feelings and goals as a composer. ${ }^{11}$ But she also experienced the spectral music of Gérard Grisey and Tristan Murail which was felt closer to her personal aesthetic. When she moved to Paris in 1982, where she has resided since, she began attending courses at IRCAM, L'Institut de recherche et coordination acoustique/musique (The Institute for Research and Coordination in Acoustics/Music). These studies helped develop her abilities to manipulate sounds and timbre through electronic and acoustic means. Saariaho describes the place as being filled with people who have "feverish feeling(s) about creation and close collaboration between the acousticians, programmers, psycho-acousticians." ${ }^{.12}$

She began analyzing living and naturally occurring sounds. Saariaho created new sounds electronically but wanted to bring that to live performance rather than just using electronic means. Her acknowledged catalogue of works begins here during her studies at

\footnotetext{
${ }^{9}$ Pirrko Moisala. "Kaija Saariaho." Urbana and Chicago: University of Illinois Press, 2009: 8.

${ }^{10}$ Nadia Sirota, "Kaija Saariaho: Ears Open," Meet the Composer, Podcast, July 30, 2015, https:/www.npr.org/podcasts/528124256/meet-the-composer.

${ }^{11}$ Pirrko Moisala. "Kaija Saariaho," Urbana and Chicago: University of Illinois Press, 2009: 8.

12 Nadia Sirota, “Kaija Saariaho: Ears Open," Meet the Compose,. Podcast. July 30, 2015. https://www.npr.org/podcasts/528124256/meet-the-composer.
} 
IRCAM. Her first listed work on her website, Im Traume, is dated 1980. Besides that single work, all of the other works were composed in a time during or after her studies at IRCAM. It seems that she found her compositional voice while in Paris, combining all of her interests and experiences.

Kaija Saariaho has enjoyed a successful career as an internationally recognized composer. She has written for solo instruments, smaller chamber ensembles, full orchestras, and operas. One example of Saariaho's success is her opera L'Amour de loin that premiered in 2000 and has had a number of performances since including the New York Metropolitan Opera in 2016. She was the first woman composer to have a work staged there in over 100 years. ${ }^{13}$

Maan Varjot is a unique entry in Saariaho's compositional output as it is the only work with the pipe organ in its instrumentation and is a good example of Saariaho's techniques and tendencies as a composer ${ }^{14}$. She uses the organ as an opposition to the orchestra, befitting her interest in dualities and dichotomies. There are timbres that the ensemble creates that seem to fit her concepts of purity of sound and the graininess of noise. Nature is present through the use of poetry and its imagery, heard in the color and timbres of the instruments. Maan Varjot also includes other elements from Saariaho's compositional style. The representative nature of this work, coupled with the use of the organ, make it worthy of further study.

\footnotetext{
${ }^{13}$ Anthony Tommasini, 2016, "Review: A Newly Relevant 'L'Amour de Loin' at the Met," New York Times, Dec 2 2016, https://www.nytimes.com/2016/12/02/arts/music/review-met-opera-amour-de-loin-kaijasaariaho.html.

${ }^{14}$ Kaija Saariaho, "Works," Kaija Saariaho, http://saariaho.org. This is the only piece with the organ listed in her complete works list from her website. If she has written other works for organ, they are not currently listed.
} 


\section{Statement of topic}

This paper seeks to show how Maan Varjot is constructed. It will include a discussion of Saariaho's compositional techniques that can be surmised from the score and use other resources to determine how the piece is built. The recording of the premiere, her writings as well as others, techniques found in her other works that may apply to Maan Varjot, and comments that she and others involved in its performance will all aid in this analysis. The goal of the paper is not to explain every pitch, but rather to examine the building blocks of Maan Varjot and construct a large-scale view of the piece.

\section{Review of the Literature}

The literature pertaining to Kaija Saariaho and her works is substantial for a living composer and it generally posits her as a post-spectralist. This makes sense because part of her training was in France within the sphere of other spectralist composers as her music is often characterized by timbral manipulation. Spectral techniques are a part of Saariaho's personal style and are procedures that play an important role in her compositional output. In particular, the technique of additive and orchestral synthesis plays an important part in her pre-compositional and compositional methods. ${ }^{15}$ But these are not the only techniques she uses, as she does not strictly adhere to any of the spectralist techniques. Rather, she incorporates these techniques along with other

\footnotetext{
${ }^{15}$ Kaija Saariaho, "Timbre and Harmony: Interpolations of Timbral Structures," Contemporary Music Review 2, no.1 (1987): 94.
} 
compositional techniques, as she deems necessary for the individual work. ${ }^{16}$ The literature pertaining to Saariaho and the techniques she uses in her music can be generally divided into the following topics: overview of spectralism and spectral techniques, theoretical models for her sound structures, analysis of her works both broad and specific, biographical essays, interviews, articles in her own words, and other related spectralist compositions for organ and orchestra.

Beginning with the literature relating to spectral music and its techniques, there is a small amount of literature that has been written in or translated to English by a handful of academics, in particular Joshua Fineberg and Julian Anderson. Most of the articles pertaining to spectralist music focus on the composers Gerard Grisey and Tristan Murail. Both were based in Paris, France and associated with IRCAM. Kaija Saariaho studied in Paris at IRCAM, where she learned spectral techniques that helped form her personal style. The connection between the spectral movement and Saariaho's development is an important one and will be taken into account in the analysis of Maan Varjot with a focus on the additive and orchestral synthesis techniques.

Of Saariaho's output as a composer, the opera L'Amour de loin, the symphony $D u$ cristal, and the double concerto ... à la fumée, the latter two coupled together by the composer as a diptych, have received the most academic attention in both articles and dissertations. ${ }^{17}$ In addition, her other operas, vocal works, and flute works have also

\footnotetext{
${ }^{16}$ Nadia Sirota, "Kaija Saariaho: Ears Open,” Meet the Composer, Podcast, July 30, 2015, https://www.npr.org/podcasts/528124256/meet-the-composer.

${ }^{17}$ Julian Anderson, "Seductive Solitary. Julian Anderson Introduces the Work of Kaija Saariaho," The Musical Times 133, no. 1798 (1992): 619. Also, please review the bibliography for dissertations by John Allen Clay, Kari Besharse, Neal Facciuto, Friedrich Heinrich Kern, Amy Lynn Prickett, Karen J. Siegel, Philip Singleton, and L.C. Reid which represent some of the more recent literature on the topic.
} 
received some scholarly attention. ${ }^{18}$ These analyses will prove useful in comparing models for her pre-compositional and compositional techniques.

There are two books specifically devoted to Kaija Saariaho available in English. The first is from Pirkko Moisala and is simply titled "Kaija Saariaho." title provides more than just a biography as part of the book is devoted to her sound and the development of her personal techniques as well. The second is a collection of articles edited by Tim Howell titled "Kaija Saariaho: Visions, Narratives, Dialogues." ${ }^{20}$ This collection contains an interview with Saariaho, perspectives on her style in the context of opera and large orchestral works, and analyses of some of her works, including an analysis of Du Cristal, ... à la fumée, and L'Amour de loin.

Kaija Saariaho has written about her music a few times. The most extensive collection is in the fifth volume of the journal Music and Literature which contains seven original articles by Saariaho and an interview with her. ${ }^{21}$ Another of her writings discusses her interest in electronic and orchestral synthesis and a sound/noise axis, where she considers equating rough, noisy textures to dissonance and clear, smooth textures to

${ }^{18}$ Camilla Hoitenga, "The flute music of Kaija Saariaho," Music \& Literature No. 5 (2014): 92-94.

${ }^{19}$ Moisala Pirkko, Kaija Saariaho (Urbana and Chicago: University of Illinois Press, 2009).

${ }^{20}$ Tim Howell, Jon Hargreaves, and Michael D. Rofe, Kaija Saariaho: Visions, narratives, dialogues, Farnham: Ashgate, 2011.

${ }^{21}$ Kaija Saariaho and et al, "Kaija Saariho," Music \& Literature, No. 5 (2014): 1-146. 
consonance. ${ }^{22}$ Pouset's article restates that idea when he describes the difference between a sine wave and white noise. ${ }^{23}$

The areas lacking in scholarship pertaining to Kaija Saariaho and her compositional output is diversity in analyses. Because the diptych Du Cristal and ... à la fume and the opera L'Amour de loin are most frequently found in the literature, gaining a variety of perspectives on how her works are understood presented a challenge. Another aspect that was challenging is the organ registration, the choice of stops, something unique to the organ. As this is her first published work to include the organ in its instrumentation, there is no literature pertaining to her compositional style and techniques as might be applied to the organ. The original copy of the score for Maan Varjot did not have a proposed registration. Saariaho revised the score in 2015 and added titles to the movements, program notes, and a proposed registration appeared in the commercially available organ score written by organist Olivier Latry.

In my research, I have only identified one other work for organ and orchestra that may use spectral techniques. ${ }^{24}$ Firmamentum was composed by Harri Viitanen who studied with Tristan Murail in Paris. While his teacher gives Viitanen a direct link to spectralism, I was unable to decipher whether or how the work makes use of spectral techniques as an analysis of this work is beyond the scope of this paper. Viitanen says the piece contains "tonal interpretations of the Zodiac constellations, different synthetic

${ }^{22}$ Kaija Saariaho, "Timbre and harmony: Interpolations of timbrel structures," Contemporary Music Review 2, no.1 (1987): 96.

${ }^{23}$ Damian Pousset, Joshua Fineberg, and Ronan Hyacinthe, "The Works of Kaija Saariaho, Philippe Hurel and Marc-Andre Dalbavie--Stile Concertato, Stile Concitato, Stile Rappresentativo," Contemporary Music Review 19, no. 3 (2000): 83.

${ }^{24}$ Michael Barone, "Selected Repertoire for Organ and Orchestra," Pipedreams, June 2011, https://pipedreams.publicradio.org/pdf/organ_orchestra_repertoire.pdf. 
scales, harmonies formed by growing interval ratios, several levels of ratios between the organ and orchestra, the chorale with variations composed in a Gregorian style, strict rhythm patterns. ${ }^{25}$ This statement found in the liner notes point to a larger set of techniques that are not limited to spectral techniques, possibly positing him as a postspectralist. Even if Viitanen's work is not overtly spectralist, Maan Varjot and Firmamentum are potentially unique works of spectral music for organ and orchestra. Firmamentum may be worth its own research and analysis as it is not in the scope of this paper.

It is possible that Saariaho treats the organ part similarly to how she treats electronic elements in her orchestration. Of Saariaho's thirty-three works of orchestral, soloist plus orchestra, and large ensemble compositions, eight of them include electronics or tape. Her four operas also include electronics as a component of their orchestration. Two of those works include Du Cristal and L'Amour de loin which have received much analytical attention and may prove useful in analyzing Maan Varjot. The organ has the ability to sustain long tones without breathing as some instruments of the orchestra require. A comparison to works that use electronics may be made if the music in Maan Varjot warrants it.

Saariaho's studies at IRCAM, her upbringing in the countryside of Finland, her love of visual art, poetry, and nature, her personal writings, and the subsequent literature written about her works all add up to how she may approach a composition. These things will all be taken into consideration in the analysis of Maan Varjot.

\footnotetext{
${ }^{25}$ Harri Viitanen, Liner notes to Firmamentum, Harri Viitanen, Grammofon AB BIS, CD-887, CD, 1997: 5.
} 


\section{CHAPTER 2}

\section{Setting the Scope: The Building Blocks and Limitations of Analyzing Maan Varjot}

On a macro level, Maan Varjot could be considered to fall in line with traditional symphonic works. The piece contains several features commonly found in works with three movements: the first movement is faster and louder, the second movement is slower and quieter, and the final movement is the fastest and loudest of the three. Though the organ part is prominently featured, its timbres are often used as another resource of the orchestra. Saariaho has stated that she does not consider the work a concerto but rather a symphonic work that features the organ. ${ }^{26}$ Olivier Latry, the organist who premiered the piece, stated the same. ${ }^{27}$

The two primary building blocks of the piece are a poem by Percy Shelley and a chord that bookends the entire work. In this way, Maan Varjot also resembles some of Saariaho's other works. Her symphonic work Du Cristal (1989) begins with an opening chord containing musical material that is continuously expanded upon throughout the piece. ${ }^{28}$ She had so much to say with that musical material that she wrote a companion work to Du Cristal titled ... à la fumèe, and she sees them as one cumulative work. ${ }^{29}$ Notes on Light, a cello concerto, also begins in a similar manner. The first thirty seconds

\footnotetext{
${ }^{26}$ Kaija Saariaho, "Maan Varjot (Earth's Shadows)," Wise Music Classical, Accessed March 7, 2020, https://www.wisemusicclassical.com/work/48887/.

${ }^{27}$ Olivier Latry in discussion with the author, October 18, 2018.

28 Jon Hargreaves, "Networks of Communication," in Kaija Saariaho: Visions, Narratives, Dialogues, ed. Tim Howell, et al. (New York: Ashgate, 2011): 180. ${ }^{29}$ Ibid. 179
} 
of the work have musical material that is expanded upon throughout the concerto. ${ }^{30}$ In this chapter, I will show how Maan Varjot, is following Saariaho's typical composition model both in terms of inspiration and musical content.

\section{Adonais}

Poetry, artwork, or nature often serve as inspiration for Saariaho's compositions. ${ }^{31}$ I do not mean that the images and ideas are directly represented by specific musical elements, but rather that they serve as a point of inspiration for the musical elements. The score for Maan Varjot quotes the 52nd stanza of Percy Shelley's poem, Adonais, an elegy for the death of John Keats.

The One remains, the many change and pass;

Heaven's light forever shines, Earth's shadows fly;

Life, like a dome of many-colour'd glass,

Stains the white radiance of Eternity,

Until Death tramples it to fragments.-Die,

If thou wouldst be with that which thou dost seek!

Follow where all is fled!-Rome's azure sky,

Flowers, ruins, statues, music, words, are weak

The glory they transfuse with fitting truth to speak. ${ }^{32}$

The poem, Shelley's lament about Keats' death, is loosely based on the Greek myth about Adonis. ${ }^{33}$ After Adonis dies, a festival is celebrated in his memory. Shelley

\footnotetext{
${ }^{30}$ Tim Howell, "Dualities and Dialogues," in Kaija Saariaho: Visions, Narratives, Dialogues, ed. Tim Howell, et al. (New York: Ashgate, 2011), 148.

${ }^{31}$ Clément Mao-Takacs, "A Conversation with Kaija Saariaho," Music \& Literature No. 5 (2014): 48.

32 Poetry Foundation, "Adonais: An Elegy on the Death of John Keats," Accessed 6 November 2019, https://www.poetryfoundation.org/poems/45112/adonais-an-elegy-onthe-death-of-john-keats.
} 
takes that story and uses it as a vehicle to mourn and commemorate the loss of his friend, Keats. Saariaho's choice to use this poem and its themes may be understood through the fact that she dedicated the piece to her father. She has made no public statements about why the piece is dedicated to her father, but the poem's themes of lament and celebration of a loved one seems fitting. ${ }^{34}$ The use of Finnish in the title Maan Varjot, which translates into English as "Earth's Shadows," has to do with her history with the organ and her experiences playing the instrument as a young musician in Finland. ${ }^{35}$ The poem points to several dualities that serve as possible inspirations for the piece, most importantly from the line that includes the title: "Heaven's light forever shines, Earth's shadows fly." Saariaho herself even notes that the organ is an excellent companion to the orchestra as it does not need to compete to be heard and can "co-exist without having to fight too much for the place in the sun."36 The organ and orchestra can act as dual forces like light and shadow in the poem. Dualities, reflections, or oppositions are an important feature of her compositional style as in Du Cristal and ... à la Fumée, Mirrors, Nymphéa and Graal théâtre. Saariaho, in her music, considers "how we perceive the world, how we distinguish one thing from another as a result of differences and oppositions." ${ }^{\text {,37 }}$

33 Timothy Clark, "Shelley after Deconstruction: The Poet of Anachronism," in Evaluating Shelley, edited by Timothy Clark and Jerrold E. Hogle, Edinburgh: Edinburgh University Press, 1996: 96.

34 I reached out to Kaija Saariaho but she was unavailable according to her agent.

${ }^{35}$ Kaija Saariaho, "Maan Varjot (Earth's Shadows)," Wise Music Classical, Accessed March 7, 2020. https://www.wisemusicclassical.com/work/48887/. See the opening paragraphs pertaining to her early years prior to becoming a full-time composition student.

${ }^{36}$ Ibid.

${ }^{37}$ Kaija Saariaho, "Timbre and Harmony: Interpolations of Timbral Structures," Contemporary Music Review 2, no.1 (1987): 97. 
Other images from the poem also inform Maan Varjot. Each movement uses a short quote from the poem that tells the listener much about the movement itself. Saariaho often uses other arts as a compositional inspiration or a starting point. In her article "Timbre and Harmony: Interpolations of Timbral Structure," she quotes Vassily Kandinsky's book Point, Line, and Plane to help describe her compositional approach, particularly with regards to form. Saariaho quotes Kandinsky: "Form is the external manifestation of inner meaning. ${ }^{\prime 38}$ Each of the movements' titles is directly related to the realization of their form. Saariaho has even stated, "When I feel I have the right title, I can focus my material. The title is very important for feeding my imagination. ${ }^{\prime 39}$ The role that the movement titles play will be discussed in Chapter 3 .

\section{The Opening Chord}

Maan Varjot opens with a chord that is the basis for much of the piece (Example 1). While Saariaho has not publicly revealed how she arrived at this particular chord, its timbrally-informed sound may be due to the use of Spectral techniques and, in the case of this chord, additive and orchestral synthesis. During a visit to Darmstadt's summer music program in 1980 and her eventual studies in Paris and at IRCAM she was introduced to techniques involving the analysis and manipulation of the harmonic spectra found in sound. ${ }^{40}$

\footnotetext{
${ }^{38}$ Ibid. 124

${ }^{39}$ Tim Howell, "Dualities and Dialogues," in Kaija Saariaho: Visions, Narratives, Dialogues, ed. Tim Howell, et al. (New York: Ashgate, 2011), 134.

${ }^{40}$ Damien Pousset, Joshua Fineberg and Ronan Hyacinthe, "The Works of Kaija Saariaho, Philippe Hurel and Marc-Andre Dalbavie--Stile Concertato, Stile Concitato, Stile Rappresentativo," Contemporary Music Review 19, no. 3 (2000): 69.
} 


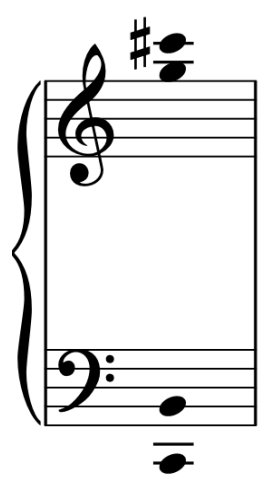

Example 1: The Opening Chord (which will be called Chord 1)

Spectralism as a genre and philosophy of music composition includes a few techniques that Saaraiho may have used while composing Maan Varjot. There are several terms related to spectralism and Maan Varjot that I will use throughout this analysis to help to show how sound and pitch can be manipulated. The first of these terms is harmonic spectrum. Joshua Fineberg defines harmonic spectra as:

"Pitched sounds [that] are often formed by combinations of sonic components (partials) which belong to a single harmonic series whose fundamental is heard as the pitch. The relative amplitudes of these various partials - at a given moment as they change in time - determine the color or timbre of a sound. The simplest harmonic spectrum is a sine wave with only the fundamental and no other partials. Most sounds, however, contain many partials of the fundamental, and the fundamental pitch can be deduced by the ear even when it is not explicitly a member of the spectrum."

Another term important to sound and pitch is frequency. Frequency is "the number of times per second that a cycle of disturbances is exactly repeated." ${ }^{, 42}$ A lower frequency cycles more slowly and therefore has a lower pitch, which is expressed in Hertz,

\footnotetext{
${ }^{41}$ Ibid. 86

${ }^{42}$ Clive Greated, "Frequency," Grove Music Online, 2001; Accessed 11 Aug. 2020, https:/www-oxfordmusiconline-

com.www.libproxy.wvu.edu/grovemusic/view/10.1093/gmo/9781561592630.001.0001/o mo-9781561592630-e-0000010215.
} 
abbreviated to $\mathrm{Hz} \cdot{ }^{43}$ For example, $\mathrm{A}$ above middle $\mathrm{C}$ on a piano typically vibrates at a frequency of $440 \mathrm{~Hz}$. An A one octave lower than the previous example has a frequency of $220 \mathrm{~Hz}$. One octave higher would be $880 \mathrm{~Hz}$ showing that the frequencies of pitches grow exponentially rather than linearly. ${ }^{44}$

In general, a harmonic spectrum of a pitched sound will create two kinds of partials from their fundamental. Partials that are whole integer frequencies from a fundamental create harmonicity. For example, if a first fundamental partial were the aforementioned $\mathrm{A}$ at $440 \mathrm{~Hz}$, the second partial would be an $\mathrm{A}$ at $880 \mathrm{~Hz}$, one octave higher at a multiple of two, a whole integer. In reality, sound is more complex and does not always align neatly to whole integer multiples. Inharmonicity is "the deviation of a set of frequencies from an exact harmonic series. ${ }^{45}$ In contrast to these is noise, which "contains a continuous distribution of energy spread over frequency (spectrum)...and has no detectable pitch. ${ }^{, 46}$ Other terms exist in the lexicon related to sound, but they are beyond the scope of this paper and the analysis of Maan Varjot. ${ }^{47}$

\footnotetext{
${ }^{43}$ Joshua Fineberg, "Guide to the Basic Concepts and Techniques of Spectral Music," Contemporary Music Review 19, no. 2 (2000): 83.

${ }^{44}$ Ibid. 82

${ }^{45}$ Murray Campbell, "Inharmonicity," Grove Music Online, 2001; Accessed 11 Aug. 2020, https://www-oxfordmusiconlinecom.www.libproxy.wvu.edu/grovemusic/view/10.1093/gmo/9781561592630.001.0001/o mo-9781561592630-e-0000013801.

${ }^{46}$ Glenn D. White and Gary J. Louie, The Audio Dictionary: Third Edition, Revised and Expanded, Seattle; London: University of Washington Press, 2005: 259

${ }^{47}$ I did attempt to create a mathematical model that broke down the opening chord to its frequencies based on its written pitches. The hope was that when other chords appeared that had a similar quality, they might be related proportionally. The mathematical model reduced the lowest and highest frequencies to a 1-100 scale. Unfortunately, this proved unsuccessful other than demonstrating what could be seen in the chords themselves: several lower pitches and several higher ones.
} 
These definitions do not exactly represent how Saariaho uses the terms 'sound' and 'noise' in her discussions of her music as described in Chapter 1, but they are important to a few spectral techniques I do want to mention that are relevant to Chord 1: additive synthesis, instrumental synthesis, and microtones. "Additive synthesis entails the building of complex sound structures by using simple sine waves as the building blocks. ${ }^{48}$ Determining the inharmonicity of some partials and gauging the noise is a part of the additive synthesis technique. This technique is usually associated with electro-acoustic instruments or instruments that create music through electronic processes. ${ }^{49}$ Instrumental synthesis, also known as orchestral synthesis, takes the same approach as additive synthesis but uses instruments as the basic building blocks of a complex sound structure. This becomes more convoluted as acoustic instruments each contain their own complex harmonic spectrum, which can create some interesting possibilities unique to this kind of process. Lastly, microtones are an important feature of these syntheses. Harmonic spectra do not adhere to equal temperament since they are frequency based. In order to find the closest approximation to a frequency, a quarter step (or smaller) microtone may be the better option ${ }^{50}$ It is important to note here that the organ is generally incapable of microtones and would not be capable of this technique. In the analysis of each movement of Maan Varjot, these techniques will be referred to when it seems Saariaho has used them. For an in depth look at the spectral techniques not discussed in this paper, see Joshua Fineberg's "Guide to Basic Concepts and Techniques of Spectral Music."

\footnotetext{
${ }^{48}$ See Appendix 1 for a definition of sine wave.

49 Joshua Fineberg, "Guide to the basic concepts and techniques of spectral music," Contemporary Music Review 19, no. 2 (2000): 84-85.

${ }^{50}$ Ibid. 85
} 
The opening chord, which I will call Chord 1 (as labeled in Example 1), features prominently in the overall structure of the work. Not only is Chord 1 featured at the beginning of the Maan Varjot, it also appears at the end of the third movement, bookending the entire piece. A variation on Chord 1 appears at the end of the first movement. Another orchestral chord bookends the second movement, "Dome," and is also likely a variation on Chord 1 . This chord will be referred to as Chord 2 and analyzed with the second movement. ${ }^{51}$ It will be shown in the analysis of the third movement that the Toccata Figure at the beginning of the third movement also shows some relationship to Chord 1. "Flowers, ruins, statues," the third movement, uses symmetry and reflection more than the other movements as it reflects the work as a whole. The placement of all of these chords shows their structural importance as seen in Example 2 and their symmetry in regard to the whole of Maan Varjot.

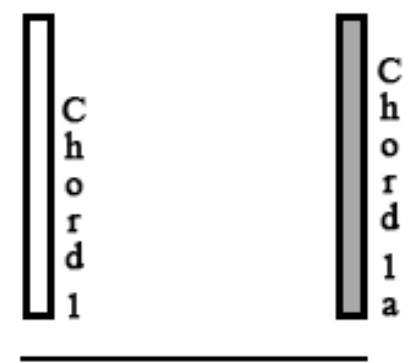

Earth's Shadows

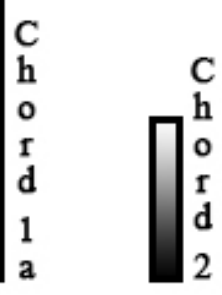

Dome

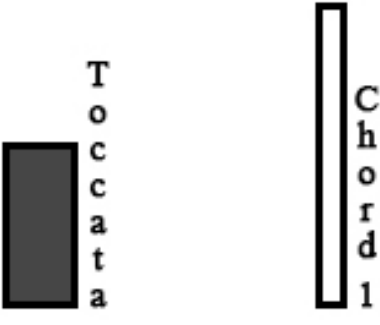

Flowers, ruins, statues

\section{Example 2 - Symmetry in Maan Varjot as a Whole}

\footnotetext{
${ }^{51}$ Examples of Chord 2 will be shown in Part 2 of Chapter 3 Because it only appears in the second movement, "Dome," its analysis will be limited to that part of the paper.

${ }^{52}$ Similar to Chord 2, The Toccata Figure will be explained in further detail in Part 3 of Chapter 3 as it only appears in the final movement.
} 
Besides the macro structures of Maan Varjot and its three movements, Chord 1 is stated by the organ three times in the opening 12 measures of the first movement, the harp plays it explicitly in measure 5 , and most of the pitches are doubled in the strings and a few other instruments. Saariaho then goes on to develop it and transform it before finally returning to it at the end of the movement. Fragments and elements of Chord 1 appear not only throughout the first movement, but in the entirety of Maan Varjot. It is clear that Chord 1, Chord 2, and the Toccata Figure hold importance to the structure of the work as a whole and, as I will attempt to demonstrate, in its details as well.

The lowest pitch written, $\mathrm{C} 2$, is orchestrated as the fundamental of an instrumental synthesis, and is possibly the fundamental of a spectral series. ${ }^{53}$ The other three pitches as written are $\mathrm{B} 2, \mathrm{G} 5$, and $\mathrm{C} \# 6$, which would then be the partials of the instrumentally synthesized series. Whether these pitches reflect an actual spectral series is again, unknown, as the process to reverse a series is beyond the scope of this paper. It is worth noting that the G5 is a partial of the $\mathrm{C} 2$ whereas the $\mathrm{B} 2$ and $\mathrm{C} \# 6$ seem to add inharmonicity to Chord 1. In the moments that the chord occurs nearly as written in this manner, the orchestra often doubles the written pitches that are played in the organ (the added complexity of the organ registration and where pitches sound is dealt with below).

The importance of Chord 1 in the work as a whole points to it being precomposed. Edward T. Cone calls pre-composition "the influence of thought about music

\footnotetext{
${ }^{53}$ The system for naming specific pitches will be the one proposed by R.W. Young in 1939 and adopted by the Acoustic Society of America. This system places middle C at $\mathrm{C} 4$. All pitches before the $\mathrm{C}$ octave repeats above are given the same number as the $\mathrm{C}$ below in that particular octave.
} 
upon thought in music. ${ }^{54}$ In other words, pre-composition is a combination of processes, choices, or decisions made early in the creation of a piece that guide and inform much of the work. One simple example of a pre-compositional decision could include instrumentation for a given commission. A technique like a twelve-tone row is a precompositional choice. Each of the twelve tones of the scale are chosen in a fixed order in which none of the pitches repeat. These are then expanded into a matrix, and used to create predetermined musical material for composers to use at their discretion. ${ }^{55}$

Besides the possible connection to spectral techniques, a few fragments can be inferred from the pitches using an analytical technique called pitch-class and set theory. Pitch-class reduces the letter-named pitches to a set of numeric integers starting where C $=0, \mathrm{C} \# / \mathrm{Db}=1, \mathrm{D}=2$, etc. and ending with $\mathrm{A} \# / \mathrm{Bb}=\mathrm{t}(\mathrm{en})$ and $\mathrm{B}=\mathrm{e}\left(\right.$ leven). ${ }^{56}$ Those latter letters refer to the first letter of the words ten and eleven. Set theory involves taking groups of pitches and comparing those groups based on their intervallic relationships in either an ordered or unordered manner. ${ }^{57}$ In combination together, pitch-class set theory involves reducing groups of pitches to a set of integers beginning at 0 with no specific

${ }^{54}$ Edward T. Cone, "Thinking (About) Music," Proceedings of the American Philosophical Society 148, no. 4 (1994): 472.

${ }^{55}$ The process and creation of a twelve-tone matrix is outside of the scope of this paper as it does not offer any relevant information into Maan Varjot other than that it creates a large amount of pitch information for a composer to use at the beginning of the compositional process.

${ }^{56}$ John Roeder, "Pitch class," Grove Music Online, 2001; Accessed 23 June 2020, https://www-oxfordmusiconlinecom.www.libproxy.wvu.edu/grovemusic/view/10.1093/gmo/9781561592630.001.0001/o mo-9781561592630-e-0000021855.

${ }^{57}$ Roeder, John, "Set (ii)," Grove Music Online. 2001; Accessed 23 June 2020, https://www-oxfordmusiconlinecom.www.libproxy.wvu.edu/grovemusic/view/10.1093/gmo/9781561592630.001.0001/o mo-9781561592630-e-0000025512. Normally in set theory, different brackets infer different things. For this paper, only the "[x,x]" brackets will be used. 
starting pitch and their respective intervals above in an equal octave of twelve tones. Therefore, a three note group making up of $[\mathrm{F}, \mathrm{G}, \mathrm{B}]$ would first be translated in pitch class as $[5,7, \mathrm{e}]$ and subsequently reduced to $[0,2,6]$ in what is called its prime form.

One important feature of Chord 1 is the half steps between several of the pitches. Considered as pitch-classes, where $B=e, C=0$, and $C \#=1$ combined with the $G=7$ form several sets that hold significance throughout the work, especially when the various sets are reduced to begin at 0 . This is most often manifested in a set that is $[0,1, \mathrm{x}]$, where $\mathrm{x}$ is an intervallic leap as in Example 3. These sets form content found throughout Maan Varjot. The second movement, "Dome," uses an $[0,1, \mathrm{x}]$ set as the melody of a choralelike theme. The final movement, "Flowers, ruins, statues," make great use of these combinations in the Toccata Figure of the organ. Saariaho gives privilege to figures that begin with a half step followed by a leap, particularly $[0,1,5],[0,1,6]$, and $[0,1,7]$. These combinations are foundational to Maan Varjot, not simply as characteristics of Chord 1, but to many musical aspects found throughout.
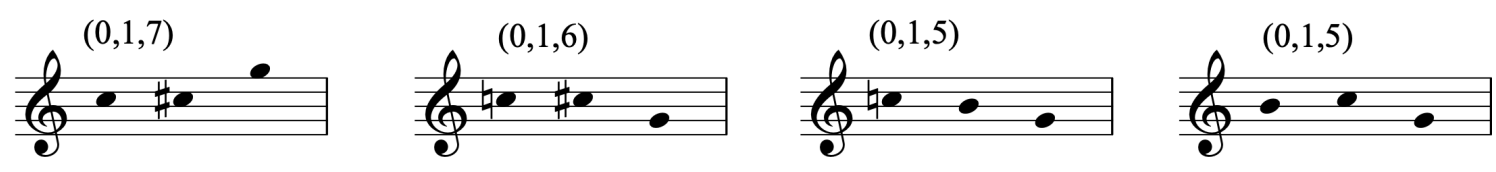

\section{Example 3 - Forms of sets $[0,1, x]$ created from Chord 1}

\section{The Organ Registration}

A unique property to the organ is that no two instruments are alike, in terms of the instruments' construction in an acoustical space as well as the groups of pipes called ranks and their general timbres built for the instrument. There is also a great tradition in 
organ building that spans centuries and regions and countries with construction and performance practices rising, falling, and eventually resurfacing again. ${ }^{58}$ This tradition includes how the pipe ranks developed. Ranks of pipes generally form singular groups of timbre, which are called stops that the organist chooses when performing works. Choosing which stop or groups of stops to use for a work for organ is called registration. ${ }^{59}$ All of this points to an inconsistency across organs that proves challenging when performing a work on the organ, let alone an analysis. Even Saariaho admits that "as every organ is different, the part sounds different with every performance." ${ }^{60}$ At the same time, though, she called the organ an orchestra, with "so many various colors.",61

The registration of works for organ can be a daunting task for a modern composer and Saariaho was concerned with retaining her identity as a composer because of the issues surrounding registration. ${ }^{62}$ The repertoire of the instrument often reflects the building and design of their respective place and time. One common example is the registration of Johann Sebastian Bach's organ works, which he rarely marked in his scores and publications. Without knowledge of how organs were constructed in $17^{\text {th }}$ and $18^{\text {th }}$ century Germany, his works are challenging to register on instruments that are not of this era and region.

\footnotetext{
${ }^{58}$ Fenner Douglass, Barbara Owen, and David Fuller, "Registration," Grove Music Online, 2001; Accessed 20 June 2020, https://www-oxfordmusiconlinecom.www.libproxy.wvu.edu/grovemusic/view/10.1093/gmo/9781561592630.001.0001/o mo-9781561592630-e-0000047609.

${ }^{59}$ Ibid.

${ }^{60}$ Clément Mao-Takacs, "A Conversation with Kaija Saariaho," Music \& Literature No. 5 (2014): 59.

${ }^{61}$ Ibid.

62 "Esa-Pekka Salonen, Kaija Saariaho and Olivier Latry introduce Saariaho's Maan varjot," Philharmonia Orchestra, Youtube video, 08:06, June 12, 2014, https://www.youtube.com/watch?v=p4lfQy-ImhY.
} 
In preparation for composing the organ part, she worked closely with the organist Olivier Latry, one of the titular organists at Notre-Dame Cathedral in Paris, France. She visited Olivier Latry twice at Notre-Dame Cathedral to listen to him accompany the Mass. ${ }^{63}$ In describing her intentions for the organ registration she said she wanted wide tessituras in the registrations. ${ }^{64}$ She also gives general dynamic markings for the organist, who would interpret them on the organ with which Maan Varjot is being performed.

Another concern when registering stops on the organ is the instrument's ability to play notes outside of the written pitch. Concert pitched stops are given a registration label of 8 '. Depending on the stop, the organ can perform pitches octaves lower and higher than the given pitch. The stops of an organ that are capable of playing pitches octaves higher than written are labeled 4' (one octave), 2' (two octaves), and 1' (three octaves). Conversely in the pedals and sometimes the manuals, the organ can play up to two octaves lower with pipes labeled with a registration as 32', though $16^{\prime}$ 'pipes sounding an octave lower are far more common. In addition to the octave displacements, most organs also have mutation stops that generally emphasize partials of the 8' stops. Mutation stops include stops called mixtures that emphasize the partials of the fundamental pitch and the fifth. Other general stops such as the Tierce $13 / 5^{\prime}$, emphasize two octaves and a third above the pitch played which is the $5^{\text {th }}$ partial above a theoretical harmonic series. The proposal given by Oliver Latry for Maan Varjot includes stops such as these, emphasizing pitches not written in the score, instead bringing out various partials of the given note. $^{65}$

\footnotetext{
${ }^{63}$ Olivier Latry in discussion with the author, October 18, 2018.

${ }^{64}$ Ibid.

${ }^{65}$ Please see Appendix 2 for a longer explanation of organ registration.
} 
With regard to the registration of Maan Varjot, there were no initial stops marked in the first edition of the full score. When I first explored analyzing Maan Varjot, I obtained a perusal copy of the score from Chester Music through their distributor in the United States, G. Schirmer, Inc. The score included a stamp with the phrase "the score may not represent the composer's final intention." ${ }^{, 66}$ Rather than give a registration suggestion, the score included dynamic markings indicating a general idea of what kinds of stops may be used. This version of the score is copyrighted in 2013 and mentions its three premieres in 2014. A newer version of the score and solo organ part became commercially available after a revision was done in May of 2015. The only discernable change was the inclusion of the poem, program notes, and titles for the movements, as well as the proposal for the registration of the organ part by Olivier Latry. The solo organ part includes more details throughout the entire work that are not included in the full score. The general proposal, a term used in France to mean registration suggestion, given by Latry in his performance notes calls for the first movement to have a constantly evolving set of colors through the registration. This continues in the second movement where Latry suggests that "the polyphonic voices should have clearly different colours." 67 He accomplished this by having each of the four polyphonic voices in the hands on four different manuals. ${ }^{68}$ The final movement suggests "changing, bright colours," again emphasizing a dynamic use of the organ registration. ${ }^{69}$

Taking these things in consideration, the registration proposal cannot be entirely relied upon as an analytical device. For the purposes of this document, registrations will

\footnotetext{
${ }^{66}$ Kaija Saariaho, Maan Varjot. London, England: Chester, 2015.

${ }^{67}$ Ibid.

${ }^{68}$ Olivier Latry in discussion with the author, October 18, 2018.

${ }^{69}$ Kaija Saariaho, Maan Varjot. London, England: Chester, 2015.
} 
be reduced first to their written pitch and when necessary, their registration. For example, Chord 1 is shown in its literal notation in Example 1 above. Taking the proposed registration into consideration, Chord 1 at the beginning of Maan Varjot would include all of the pitches in Example 4. Not all of those pitches are heard or perceptible because of how the pipes are voiced, their placement within the organ chamber, or the fact that some of the upper pitches emphasize partials of a fundamental pitch.

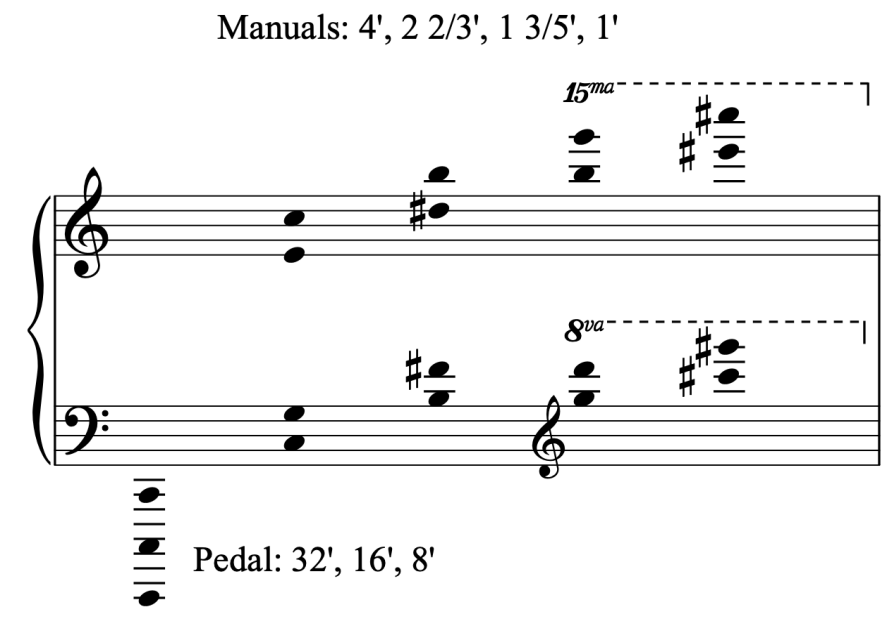

\section{Example 4: Total possible pitches based on the notation and organ registration}

In order to reduce the notes to their perceptible pitches, I used the premiere recording of Maan Varjot and placed Chord 1 against a waveform model, which will be called the Comparative Model, to produce the best perceivable pitches (Example 5). Between the registration and the written pitches both in the organ and orchestra, this may be the best realization of the way we perceive Chord 1 in its three iterations in the work. This is a good example of where the recording, registration, and analysis combine to propose a best perceptible version in the analysis of the music. Please refer to Appendix 1 for a detailed accounting of how this Comparative Model was created. 


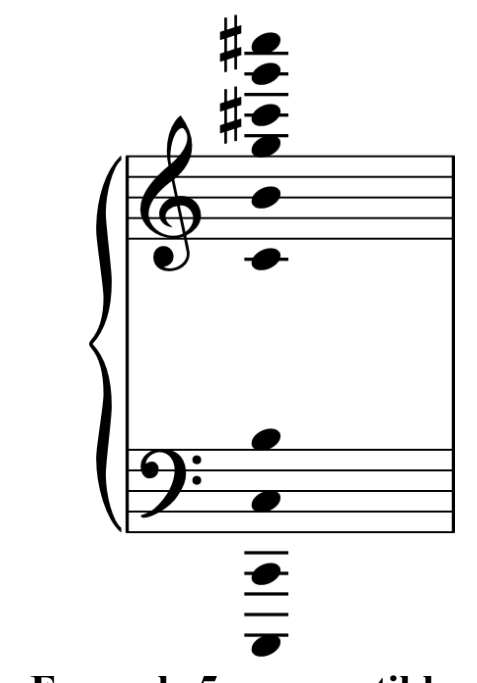

Example 5 - perceptible pitches of Chord 1

\section{Premiere Recording}

As there is only one recording commercially available, it will be the primary source for aural analysis. Maan Varjot was commissioned and premiered by the Montreal Symphony Orchestra, the Orchestre national de Lyon, and the Philharmonia Orchestra in London. The recording used for this analysis is from the initial premiere with the Montreal Symphony Orchestra with Kent Nagano conducting. I pursued other performances of Maan Varjot, including an additional performance that occurred at the Walt Disney Concert Hall, but either the recordings were inaccessible or no recording was made. Nagano conducted the second premiere in Lyon, France. Esa Pekka-Salonen conducted the final premiere in England. Pekka-Salonen also conducted Maan Varjot at the Walt Disney Concert Hall but that performance was not recorded.

The premiere recording also introduces a couple of challenges with regard to the perception of the work. The stereo nature of the recording does not capture the true 360degree nature of the performance. For example, as mentioned above, Latry played the individual polyphonic lines in "Dome" by performing the four contrapuntal lines in the 
hands on four separate manuals. ${ }^{70}$ In the concert hall space, this would be perceptible by an audience as each voice, or rank of pipes, would be in a different space within the organ chamber. This is relatively imperceptible in the recording due to the limitations of the two-channel stereo recording. The second challenge is that Latry's proposal for the registration was published after the premiere of the work. Since the work was premiered before the organ registration was published as a part of the score, the recording will be used as a cross reference between the proposed registration and this particular performance's recording and realization of the registration.

Each of the elements listed above will be used to create the best possible analysis. Between the meaning in the poem, Chord 1's possible spectral origins through orchestral synthesis, the pitch-class sets Chord 1 produces, the registration, and the recording, an analysis should be achievable. Since this analysis hinges on Chord 1, the first movement, "Earth's Shadows," is the best place to begin.

${ }^{70}$ Olivier Latry in discussion with the author, October 18, 2018. 


\section{CHAPTER 3: Analysis}

\section{Part 1 - I. Earth's Shadows}

"Heaven's light forever shines; Earth's shadows fly"

\section{The Poem}

This line from Adonais is instrumental in the construction of the first movement of Maan Varjot. The dualistic nature of the two images, heaven's light and earth's shadows, is important to a number of elements in the music. The two images are in direct contrast, yet compliment one another: light is the source of the shadow. This dualism is certainly shown in the contrast between the organ and the orchestra in this movement. For example, the orchestra at times acts as the sun or heaven's light, and the organ acts as the clouds that cast a shadow on the earth and vice versa.

The dualism of the poem, the light and shadow, can be interpreted in two major ways: the structural form of the work and in terms of orchestration where part of the orchestra is background to another that is foreground. The larger sections of the movement have an overall structure of AB-B'A' or specifically A(introduction)-BC(interlude)-B'-A'(coda). This structure is also reflected in its use of Chord 1 , which is used primarily in the A sections. As will be seen later in the analysis, at least the first B section makes use of an expansion and elaboration of Chord 1, which will be called the Elaboration Chord. In the largest parts of the movement, the two B sections, there is foreground material and background material. Using ideas and images from the poem, it is as if the foreground material is the light and the background is the shadow. In Example 6 , the organ in dark gray and the orchestra in light gray shows the exchange between which part takes the light and shadow, the foreground and background. The foreground 
material is characterized by wide leaps and jagged rhythms. The background is less about the specific pitch material and more about orchestrally synthesized chords, related to Chord 1 and other material found in the movement. The foreground and background material are defined in more detail below.

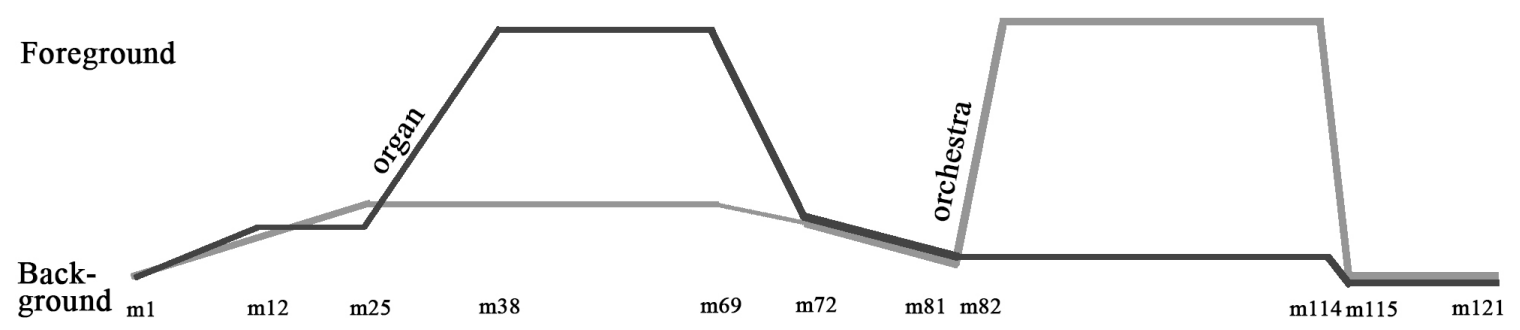

\section{Example 6 - Foreground and background/light and shadow in "Earth's Shadows"}

Another way to think about the poem and structure is through Saariaho's choices regarding tempo changes and Rehearsal Marks. Example 7 is a general overview of "Earth's Shadows" and includes the recording's time markings, measure numbers, tempo, and Rehearsal Marks. With only one exception, during measures 13-24, Saariaho marks each point described in the arch of the movement's mirror either with a tempo indication or with a Rehearsal Mark. The macro form, the larger sections of the work as related to the poem, are also divided into their smaller pieces under the micro column.

I. Earth's Shadows

\begin{tabular}{|l|l|l|l|l|l|}
\hline Macro & Micro & Time & $\begin{array}{l}\text { Measure } \\
\text { Number }\end{array}$ & $\begin{array}{l}\text { Tempo and Rehearsal } \\
\text { Mark }\end{array}$ & Description \\
\hline A & a & $0: 00$ & Mm 1-12 & $\begin{array}{l}\text { Misterioso ma intense; } \\
\mathrm{q}=\mathrm{c} .69\end{array}$ & $\begin{array}{l}\text { Introduction of Chord 1 in its original } \\
\text { form; highest pitches of the } \\
\text { Elaboration Chord in m.6. }\end{array}$ \\
\hline
\end{tabular}




\begin{tabular}{|c|c|c|c|c|c|}
\hline & $a^{1}$ & $0: 31$ & $\mathrm{Mm} 13-24$ & & $\begin{array}{l}\text { Development and elaboration on } \\
\text { Chord 1; two parts of Elaboration } \\
\text { Chord included with an emphasis on } \\
\text { the highest figure. }\end{array}$ \\
\hline & $a^{2}$ & $0: 57$ & $\mathrm{Mm} 25-37$ & RM 1 & $\begin{array}{l}\text { Final transition into Elaboration } \\
\text { Chord lowest pitch has descended to } \\
\text { B; Elaboration Chord heard in } \\
\text { completion before the beginning of } \\
\text { B. }\end{array}$ \\
\hline $\mathrm{B}$ & $\mathrm{b}$ & $1: 27$ & Mm 38-52 & $\begin{array}{l}\text { A tempo; Intenso, } \\
\text { energico; RM } 2\end{array}$ & $\begin{array}{l}\text { Jagged, rhythmic foreground material } \\
\text { is in the organ; chordal background } \\
\text { figures are ascending from the lowest } \\
\text { pitch. }\end{array}$ \\
\hline & $b^{1}$ & $2: 04$ & Mm 53-72 & RM 3 & $\begin{array}{l}\text { Foreground material continues in the } \\
\text { organ; background figures begin to } \\
\text { descend from the highest pitch; at } \\
\text { 2:30, Elaboration Chord is heard } \\
\text { again in the organ. }\end{array}$ \\
\hline $\mathrm{C}$ & - & $2: 38$ & Mm 73-81 & $\begin{array}{l}\text { Meno mosso; } \\
\text { q=c. } 54 \text {; Calmo ma } \\
\text { intense; RM } 4\end{array}$ & $\begin{array}{l}\text { Pitches of Elaboration Chord are } \\
\text { stripped away until a unison A\# is } \\
\text { heard over } 6 \text { octaves; fermata and } \\
\text { decrescendo to crescendo into B' at } \\
\text { m81. }\end{array}$ \\
\hline $\mathrm{B}^{\prime}$ & $\mathrm{b}^{2}$ & $3: 20$ & Mm 82-97 & $\begin{array}{l}\text { Tempo primo; Energico, } \\
\text { tulmotuoso; RM } 5\end{array}$ & $\begin{array}{l}\text { Jagged, rhythmic foreground material } \\
\text { is in the orchestra; background } \\
\text { chordal material begins to ascend in } \\
\text { the organ starting at its lowest } \\
\text { notated register. }\end{array}$ \\
\hline & $\mathrm{b}^{3}$ & $3: 59$ & Mm 98-114 & RM 6 & $\begin{array}{l}\text { Foreground material continues in the } \\
\text { orchestra with the introduction of the } \\
\text { descent figure; background continues } \\
\text { in the organ as it ascends to A\#6 in } \\
\text { m103 (4:14). }\end{array}$ \\
\hline$A^{\prime}$ & $a^{3}$ & $4: 41$ & Mm 115-121 & $\begin{array}{l}\text { Meno mosso; Calmo, } \\
\text { misterioso; RM } 7\end{array}$ & $\begin{array}{l}\text { Return to Chord } 1 \text { which now } \\
\text { replaces G5 with A\#6 from } \\
\text { Elaboration Chord; bass descends } \\
\text { from B2 to C2, transitioning to Chord } \\
1 \text {; ends with the organ solo. }\end{array}$ \\
\hline
\end{tabular}

Example 7 - Formal overview of "Earth's Shadows"

Shadow, besides being contrast to light, is also a reflection of the object that the light is shining upon. This idea of something being reflected is an important concept not only to the orchestration in the B sections, but to the form of "Earth's Shadows." This section takes on the form of a musical mirror, a kind of arch form where the B' section is a reflection of the first $\mathrm{B}$ section. This is shown in terms of timbral color, where the 
orchestra as background relies more upon extended techniques such as flutter-tonguing in the woodwinds, wide vibratos, sul tasto, sul ponticello, and pizzicato in the strings, to name a few. The organ as background in B' does not include the higher-pitched stops and mostly uses 8 ' Foundation stops: flutes and principle stops at concert pitch. When the organ has the foreground material, it includes registrations that span more octaves and louder timbres.

The foreground is characterized generally by more jagged and rhythmic motifs in comparison to the general sustained notes of the background and there is a correlation between the material of the two B sections. The minor ninth leap in the organ between Ab4 and G3 beginning at measure 41 is also found in the harp and then the vibraphone in measures 84, 85, and 89 (Example 8A), and is an example of the foreground rhythmic motifs. A brief descending motif that starts at two different pitches is played by the organ numerous times and appears first in measures 46 and 50 (Example 8B). This descending motif moves to the first violin immediately at the beginning of the B' section and appears many more times across various instruments (Example 8C). In measure 89, the violin imitates the motif from the organ in measure 46. The organ's final descent in the B section (Example 8D) also appears at the end of B', first in the Bb Clarinet and then the Bassoon in measure 107 (Example 8E). These are the primary examples of the foreground material, the light, found in both sections but many of these motifs are also woven throughout the music in small ways. For example, the descending figure from Example $8 \mathrm{~B}$ is found in the piccolo in measure 83. 
A)
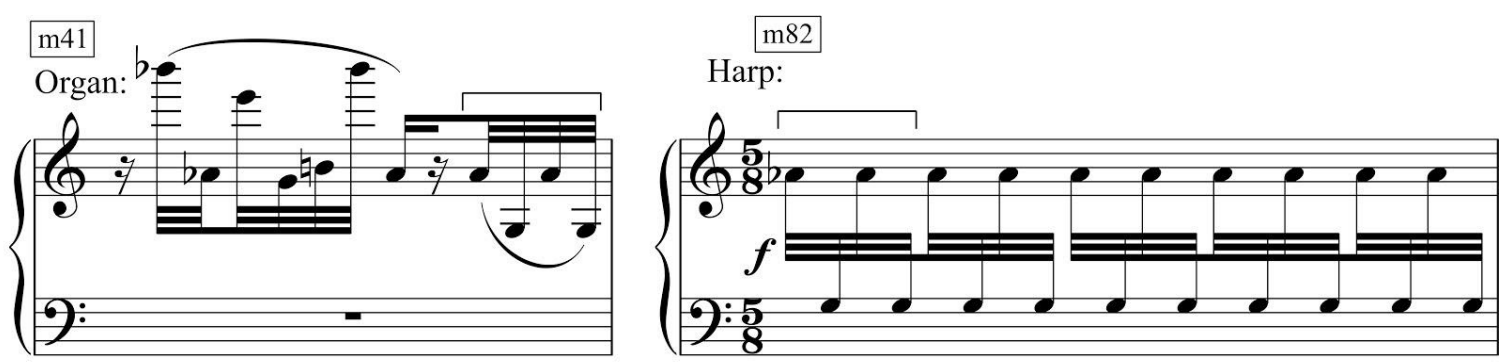

B)

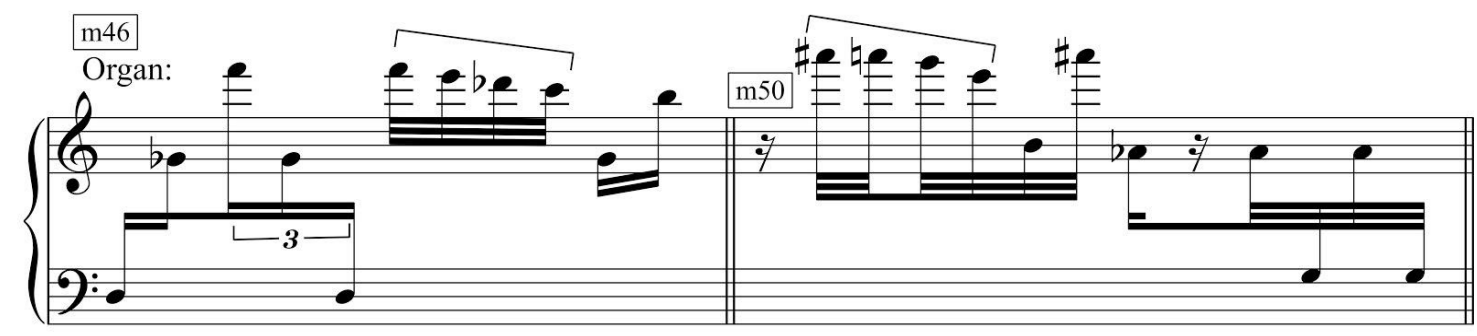

C)

mm 81-82

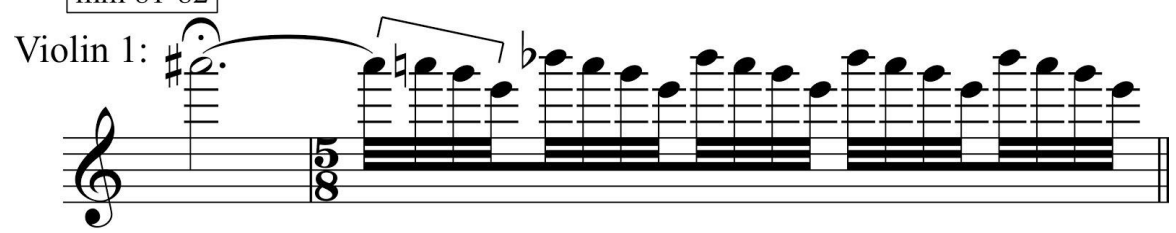

D)

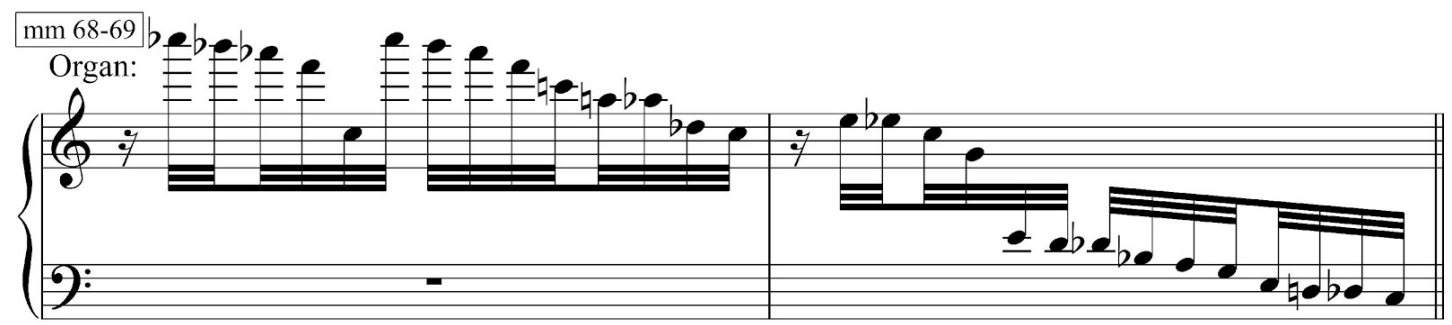


E)

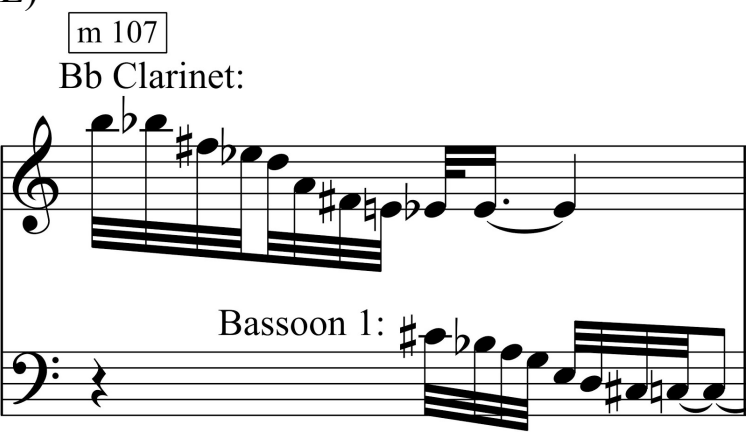

\section{Example 8 - Various foreground motifs found in the B sections of "Earth's Shadows"}

Each of these motifs do have an element in common: the $[0,1, \mathrm{x}]$ building blocks. The four-note figure found in the organ and in the violins in Examples 11b and 11c can be reduced to $[0,1,3,6]$. The $\mathrm{Ab}$ to $\mathrm{G}$ in Example $8 \mathrm{~A}$ is simply $[0,1]$. The descending runs in Examples 8D and 8E are characterized by half steps and leaps, almost in alternation from one another. It seems clear that the $[0,1, \mathrm{x}]$ building block played an important role in the development of these motifs for the foreground material.

\section{Elaboration of Chord 1}

At approximately one and a half minutes, in measures $35-37$, the orchestra and organ have transitioned from the simplicity of Chord 1 to a far more complex and noisier chord, which I have labeled the Elaboration Chord. This chord's fundamental is B2 with a C3 right next to it, possibly an inversion of the Chord 1's lower pitches. This chord seems to be built in part by the set $[0,1, \mathrm{x}]$ particular to the lower pitches. The Elaboration Chord may be Chord 1 with more pitch information in an orchestrally synthesized manner. When the two chords were juxtaposed on one another using the sine wave 
Comparative Model, there was a strong perceivable connection between the two. ${ }^{71}$ This analysis was done after the Elaboration Chord was reduced to its most perceptible form.

The organ registration complicates the Elaboration Chord's notation. The chord is arpeggiated entirely upward: first in pedals, second in the left hand and finally in the right hand. Taking the notes literally as written, the pedals would sound above the left hand (Example 9A). When the registration is taken into account, which includes 16' and 32' pipes in the pedals, it is more likely to be heard as an octave lower (Example 9B). Lastly, the score is marked forte implying that 4', 2', Reeds, and Mixture stops should be included. This is the registration that can be heard in the recording. This makes the arpeggiated Elaboration Chord sound like the pedals are an octave lower and the left hand is perceived to be an octave higher (Example 9C).

A)

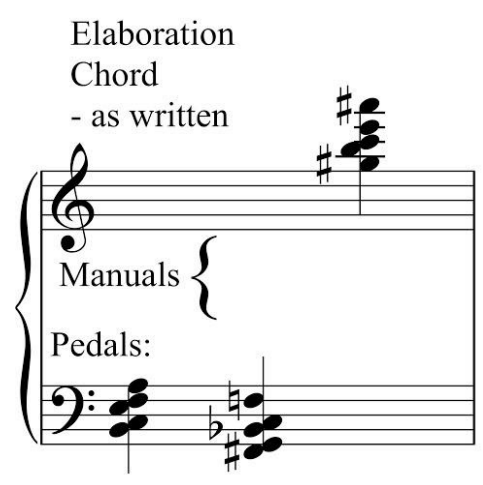

B)

Elaboration

Chord

- sounding with

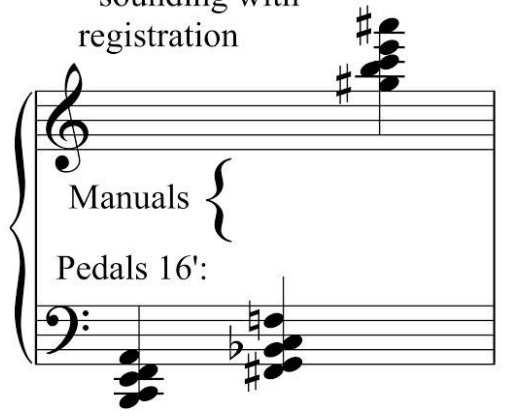

C)

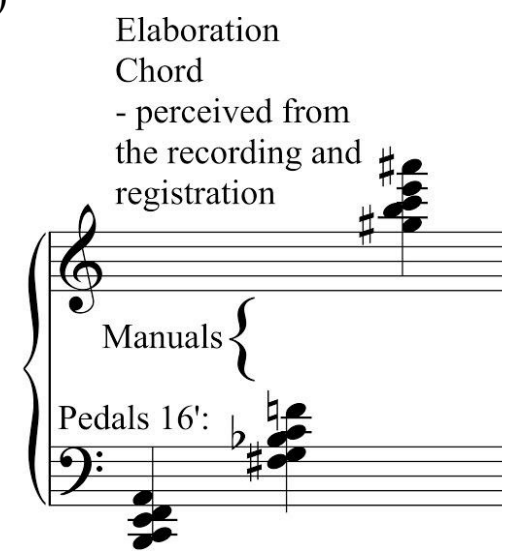

Example 9 - Perceivable pitches in the Elaboration Chord

While the focus of the first 12 measures is Chord 1, part of the Elaboration Chord first appears in measure 6, arpeggiated in the right hand of the organ. From measure 13 until the beginning of the $\mathrm{B}$ section, the music transitions and transforms from the

${ }^{71}$ Please see Appendix 1. 
Spectral Chord to the Elaboration Chord more quickly. Elements of the Elaboration Chord also appear in measures 14, 16, 19, and 22-23 often accented by other instruments in the orchestra such as the piccolo on the highest pitches. The Elaboration Chord is fully presented in measures 35-37 in the organ part and augmented with quarter-tones in the strings. This transition from Chord 1 to the Elaboration Chord can be seen in Example 10, which shows how regularly the new pitch material appears.

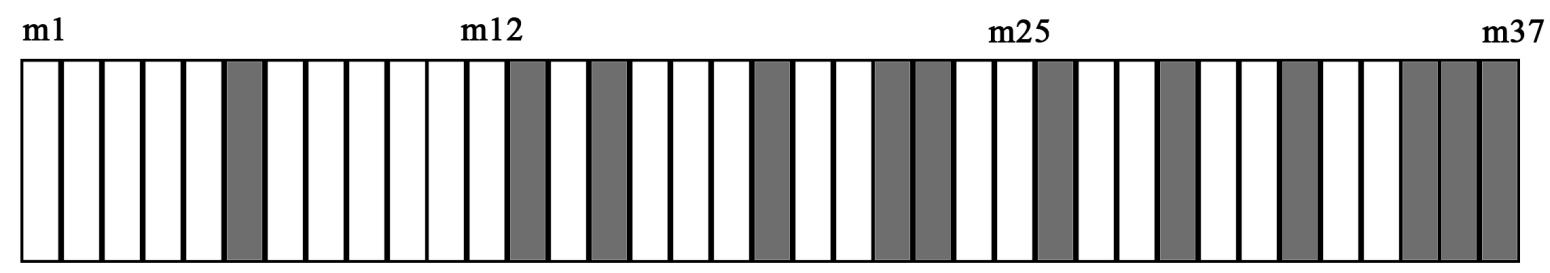

\section{Example 10 - The regularity of the Elaboration Chord pitch material in section A}

Saariaho presents Chord 1 plainly in the opening of "Earth's Shadows." Within a few moments though, she allows new pitch information to creep in, preparing the listener for a more complicated chord, the Elaboration Chord. It is possible that the two are connected as one is born out of the other, which is another possible allusion to the light and shadow of the poem. At the end of the movement, Saariaho combines aspects of both chords, with a particular emphasis on the highest pitch of the Elaboration Chord, A\#6. Since the middle point of the piece also sits on an A\#, this note has significance.

Knowing where aspects of the Elaboration Chord appear, it is now easier to go back to the opening A section to see how the transition from Chord 1 to the Elaboration Chord is achieved. These motifs appear in a similar manner to how they are used in the B sections. For example, in measures 18 and 21, there is a short motif between Gb3 and F4 in the organ part that is similar to Example 9A. The marimba and harp expand those 
pitches to more closely resemble that motif in measures 26,31 , and 34 . The Bb Clarinets introduce the Example 9A figure in measures 27 and 33 for a brief moment. The G5 and C\#6 from the Chord 1 are also present in the organ, piccolo, vibraphone, and first oboe. All of these examples, when considered together, form a bridge between the organ and the orchestra, each acting as both light and shadow in turn.

The closing $\mathrm{A}^{\prime}$ acts more as a coda than it does as a transition like the opening A section. In fact, it contrasts section A and how Chord 1 is introduced as it blends the A\# from the Elaboration Chord into Chord 1. The timpani, from measure 115 (Rehearsal Mark 7), includes glissando transitions from $\mathrm{B} 2$ to $\mathrm{C} 3$ to $\mathrm{B} 2$ to $\mathrm{A} \# 2$ to $\mathrm{B} 2$, emphasizing both the lowest and highest pitch of the Elaboration Chord and the second pitch of Chord 1. Other instruments do this as well. The bassoons are in unison on $\mathrm{B} 2$ until measure 117 when the bassoon 2 moves to the C2. This reemphasizes Chord 1's importance as bookends to movement. With regard to pitch organization and purpose, the $\mathrm{C}$ interlude is quite straight forward. Its purpose is simply to be the pivot on which the movement turns. Once the Elaboration Chord is stripped of most of its pitches, only the A\# is left in six octaves with the orchestra and organ. A decrescendo followed by a crescendo gives the perception that the music has hit a turning point and then is reflecting back from that point.

It is not until measure 117 that the $\mathrm{C} 2$ of Chord 1 returns after the $\mathrm{B} 2$ of the Elaboration Chord glissandos down in the double bass. This is reinforced by the organ pedal, tuba, and bassoon joining the double bass and arriving at $\mathrm{C} 2$ in measure 117. After venturing away from Chord 1 in the long middle section, this is the moment that "Earth's Shadows" comes back to its place of pure sound, more simple and pure than the noise of 
the B sections. As Saariaho states, the sound/noise axis is an abstraction, but the movement begins in her idea of a pure sound (A), moves away to noise (B), pauses on an important note $(\mathrm{C})$, then moves back to noise $\left(\mathrm{B}^{\prime}\right)$, and finally returns to pure sound that is slightly changed from the opening (A'). ${ }^{72}$

\section{Pitch Organization}

Broadly speaking, the various sections of "Earth's Shadows" are characterized by the bass pitch moving upward before returning to the original lowest pitch of Chord 1 . The piece begins with the Chord 1's C2 pitch that gradually moves towards the Elaboration Chord, with lowest pitches of $\mathrm{C} 3$, then B2. As the A section moves into the B section, the $\mathrm{C}$ pitch gradually moves downward to B. At the end of the B section, when the Elaboration Chord is restated, it is accompanied by the strings descending and ascending to a unison A\# across numerous octaves.

The one noticeable difference between the two B sections, in regards to their pitch content, is an A4 in B' is found nearly throughout the entire section. It is passed between a variety of instruments, but it is regularly found in the strings, vibraphone and marimba. The first B section does not seem to contain a pitch that is nearly constant, but both sections do contain a $\mathrm{C} 2$ in the organ, cellos, and double basses at the beginning. In both B sections, the C2 disappears after each B sections begins as seen in Example 11.

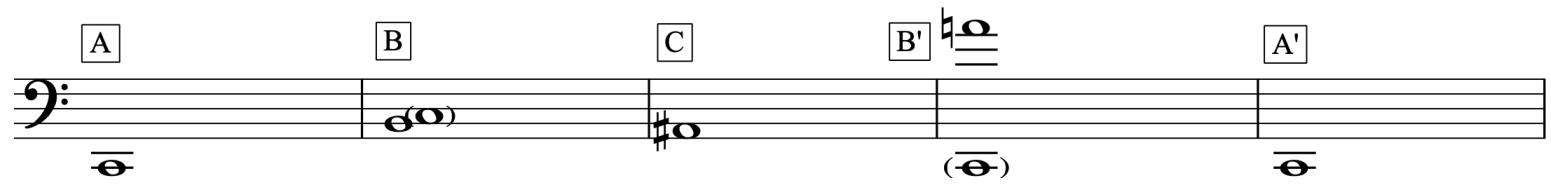

Example 11 - General bass movement through "Earth's Shadows"

${ }^{72}$ Kaija Saariaho, "Timbre and harmony: Interpolations of timbral structures," Contemporary Music Review 2, no.1 (1987): 94. 


\section{Background Material}

In the background material found in the two B sections, (the orchestra in B and the organ in B'), the timbre seems to be more important than the specific pitches. This may be a result of an orchestral synthesis process as the background material could be generally characterized as instrumentally synthesized chord structures. Because the mirror is more aesthetic than pitch specific in the background, it is less obvious than in the foreground and its related material as shown above. That may be due in part to the technical limitations of a single organist compared to the resources of the full orchestra.

The orchestra in the B section can be split into two distinct parts: the strings in pizzicato with percussion and harp in a steady pulse, and the winds creating small chord timbres while flutter tonguing. Together they create orchestrally synthesized chords with a fair amount of noise. There are some common pitches between the two groups. From Rehearsal Mark 2, the lowest pitches of the strings are kept in common with the winds, first with the double bass and tuba, bassoon and harp, then the cello and bassoon. They outline the pitches $\mathrm{C} 2, \mathrm{Db} 2, \mathrm{~Eb} 2, \mathrm{E} 2$, and $\mathrm{C} \# 3$ as the orchestra builds up each of the chords. At Rehearsal Mark 3, the chords change from ascending up from the lowest pitch to descending from the highest. The chord at the third Rehearsal Mark has a C\# doubling between the lower divisi violas and oboe 1. The final two descending chords have doubled high notes between the piccolo and violin 1, E6 and F\#6.

The organ in B' is doing something quite different compared to the orchestra in B. Rather than build short sonorities, the organ simply progresses from its lowest 32' and 16' Foundations at Rehearsal Mark 3 in the pedal C2, moving into the left hand at 16'and 
$8^{\prime}$ Foundations. Afterward, the score subtracts the $32^{\prime}$ in the pedal and $16^{\prime}$ in the manuals leaving only 8 ' Foundation stops. The organ gradually ascends, nearly chromatically, to a high A\#6 that remains until the end of the movement. Perceptibly, judging from the recording and the way it is performed, the organ blends into the background making it difficult to specify its pitches until it reaches the A\#6. This can be seen in Example 12, which shows the organ's background material in the beginning of B' from measures 82 86.
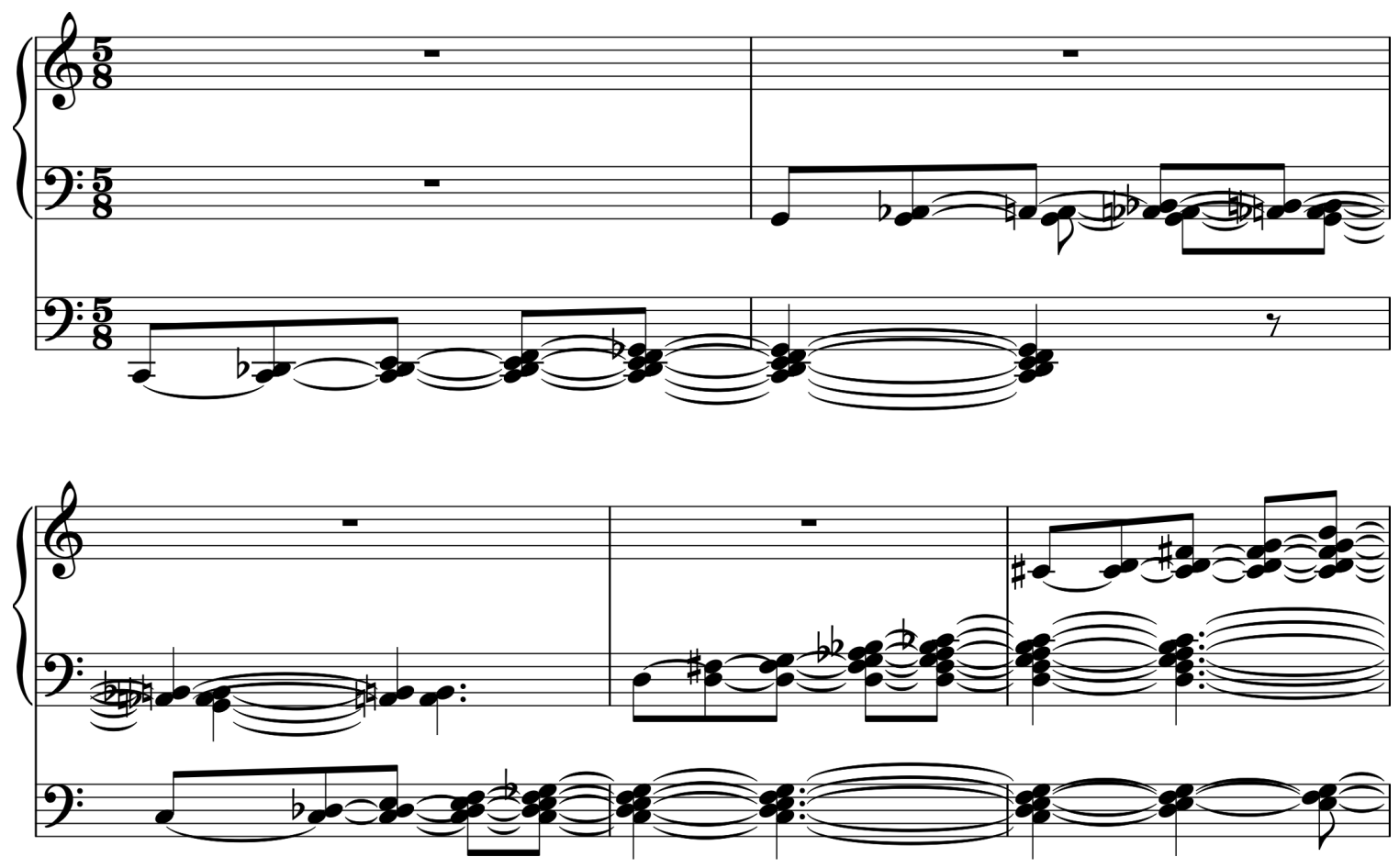

Example 12 - B' background material in the organ solo part

The way Saariaho composes the foreground and background to interplay and cross each other allows for both the organ and orchestra to have a chance to be pitch centric in the foreground and more timbral in the background. In this way, both the organ 
and orchestra get a chance to be "Heaven's light shining," foreground, and "Earth's shadows," background. This is especially seen in the foreground material of the B sections where B has the organ as "Heaven's light" and in B' where their roles reverse and the orchestra is "Heaven's light." The form of the piece also reflects this duality in that $\mathrm{A}$ and $\mathrm{B}$ form a pair that has a shadow, or mirror, in B' and A'. As duality, reflection, light and shadow have played an important role in "Earth's Shadows," the next movements will continue this idea. "Earth's Shadows" ends nearly where it began and "Dome" does something very similar. 


\section{Part 2 - II. Dome}

"Life, like a dome of many-colour'd glass"

\section{The Poem}

The second movement of Maan Varjot is built based on the simple visual of a dome which, in the case of the poem, possibly represents the sky. In a similar fashion to the first movement, much of this movement's material is built both from the visuals found in the text of the poem and Chord 1. The first movement had two complimenting and contrasting ideas from the poem that informed the orchestration and form. "Dome" seems to be doing something similar with light and color.

For this movement, there are a couple of possible images Saariaho could be drawing from. The first could be that Shelley is referring to the sky in this line of the poem. More specifically, it could be the transformation in the colors of the sky from dawn to dusk. The interpretation I have given "Earth's Shadow's" imagery comes from the relationship between the sun and the clouds, the light and shadow. This is complimentary to another possible image that emerges from the poem: light shining through stained glass or shining through clouds like stained glass. As the sun moves throughout the day, it illuminates different aspects of a stained-glass window.

The first image of the sky changing from dawn to dusk could be interpreted in the movement's form. "Dome" begins and ends with nearly the same four measures. The only difference is in the timbral choices Saariaho makes in the orchestrally synthesized chord that appears in measure four and the final measure of the movement. This will be described in more detail below. Since this sort of bookending is used consistently across 
Maan Varjot as a whole, it is likely to have some significance. These beginning and ending points demonstrate that the movement is starting and ending in the same place: a departure from a place of calm and purity of sound to a noisier place before a return to calm.

"Earth's Shadows" does something similar formally, but "Dome" does not have two sections that mirror each other. Rather, like a literal dome, the piece is in an arch, travelling from a place of stability to instability and back. More specifically, the general register of the instruments, particularly the organ, moves upward until they reach their nadir and then begin to descend, ending where the movement began. This is less a formal arch form $\left(\mathrm{A}, \mathrm{B}, \mathrm{A}^{\prime}\right)$ and more based on perception and register. There are many rising figures until Rehearsal Mark 10, where a descending figure is introduced. The movement begins quietly and builds in an upward manner, in terms of tessitura, dynamics, and most importantly, in the development of what will be called the Chorale, before descending and getting quieter to the end of the movement.

\section{The Chorale}

The organ has a rich liturgical tradition, particularly in the Christian tradition, of accompanying communal song. The term "hymn" and "chorale" have often been interchangeable in this tradition, but can have more distinct and nuanced meanings. The term hymn is often given a more generic meaning of a song in honor of god. ${ }^{73}$ Hymns are not necessarily associated with a specific religion. Chorale on the other hand, is first

\footnotetext{
${ }^{73}$ Warren Anderson, et al. "Hymn," Grove Music Online. 2001; Accessed 23 Apr. 2020, https://www-oxfordmusiconline-

com.www.libproxy.wvu.edu/grovemusic/view/10.1093/gmo/9781561592630.001.0001/o mo-9781561592630-e-0000013648.
} 
associated with the German Lutheran hymn tradition as ushered in by Martin Luther. ${ }^{74}$ One of the reforms Martin Luther sought was to include communal vernacular song as a part of public liturgical Masses.

An example of a chorale that Luther wrote is "Ein feste Burg." This setting of the $46^{\text {th }}$ Psalm is likely based on a polyphonic source with a more complex rhythm. ${ }^{75}$ Example 13 is the opening two phrases of "Ein feste Burg." This chorale's four-part setting is an example of the German chorale tradition. Each voice has an individual horizontal line that, when combined together, create vertical harmonies.
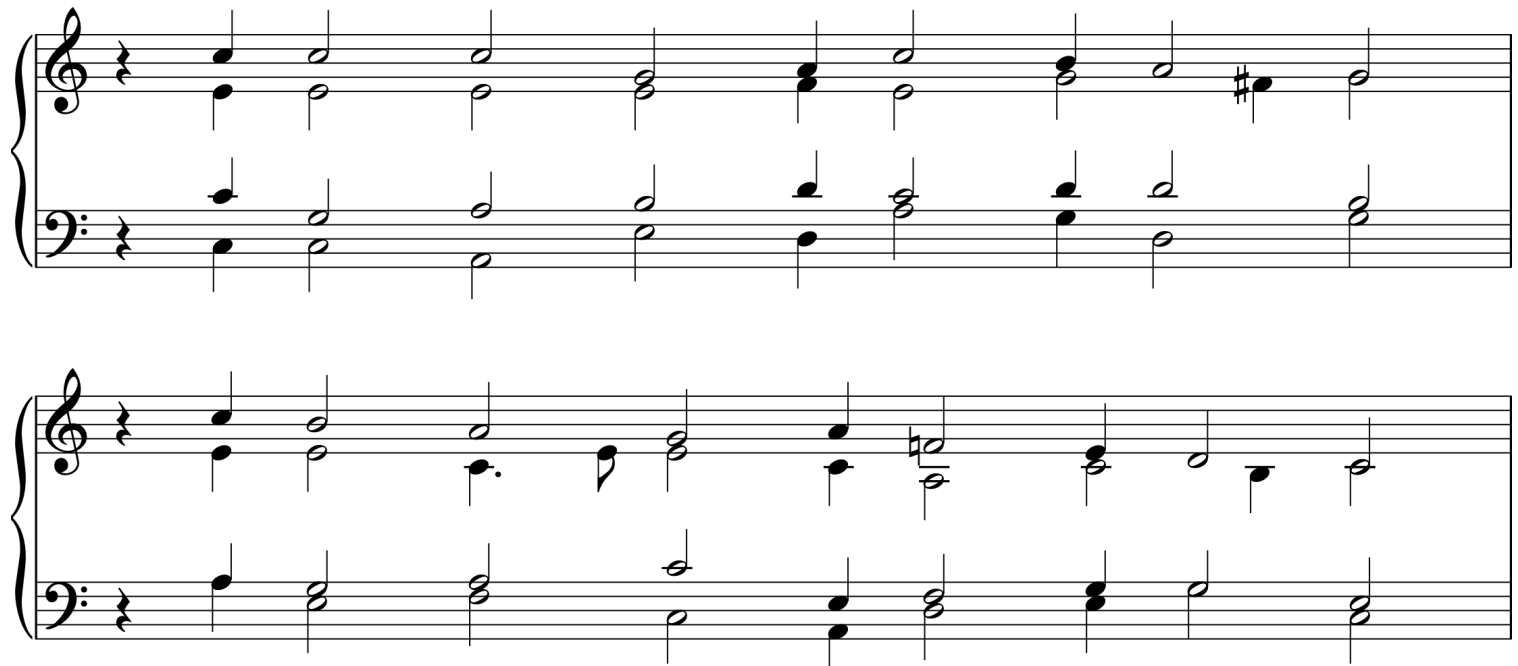

Example 13 - "Ein feste Burg," chorale written by Martin Luther

"Dome" begins with the organ part in what is best described as a polyphonic chorale, similar to the chorale tradition described above. It is clearly laid out in the score

\footnotetext{
${ }^{74}$ Robert L. Marshall and Robin A. Leaver, "Chorale," Grove Music Online. 2001; Accessed 23 Apr. 2020, https://www-oxfordmusiconlinecom.www.libproxy.wvu.edu/grovemusic/view/10.1093/gmo/9781561592630.001.0001/o mo-9781561592630-e-0000005652.

${ }^{75}$ Ibid.
} 
through the beaming and Latry's proposal stating that the "polyphonic voices should have clearly different colors. ${ }^{, 76}$ Latry realized this by performing each individual voice on a different manual. ${ }^{77}$ The uppermost line as soloed out by the registration of the organ will be given the term the Chorale melody. Any sections in "Dome" that resemble the general polyphony and aesthetic of this opening will be referred to simply as the Chorale. The Chorale melody is dominated generally by the half-step to a leap set shown in the building blocks (Example 13). The opening Chorale section also contains several other polyphonic lines that are imitated in other moments and characterized by their rhythms and the $[0,1, \mathrm{x}]$ intervallic relationship. The vertical relationship that the Chorale creates will be discussed further below.

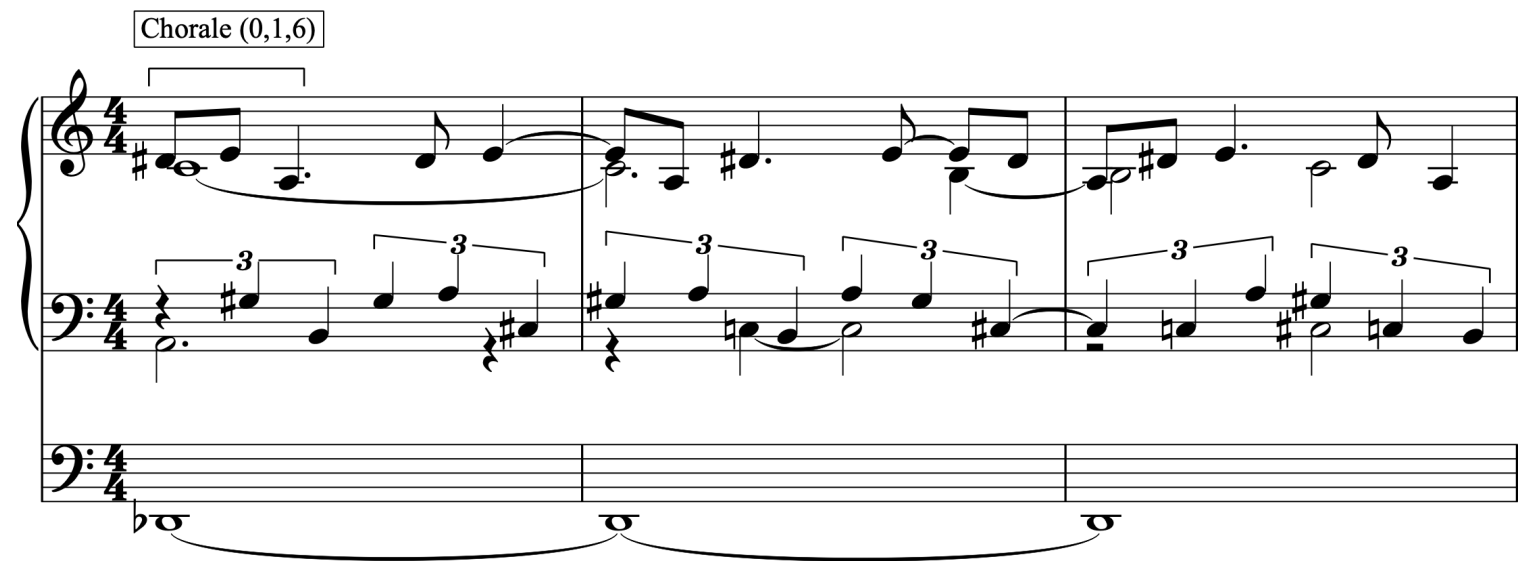

\section{Example 14 - Organ solo part, mm 1-3}

The Chorale melody is developed when an additional note is added to the $[0,1, \mathrm{x}]$ set creating an $[0,1,4,7]$. The Chorale melody is continued immediately in two violin solos and at Rehearsal Mark 8 in the trumpet. The $[0,1,4,7]$ carries on in the organ solo in

\footnotetext{
${ }^{76}$ Kaija Saariaho, Maan Varjot. London, England: Chester, 2015.

${ }^{77}$ Olivier Latry in discussion with the author, October 18, 2018.
} 
inversion. The $[0,1,6]$ can be seen in the uppermost voice in the right hand. Example 15 shows this development in the Chorale melody that occurs in measure 9 as well as the continued use of the $[0,1, \mathrm{x}]$ set in the other voices.

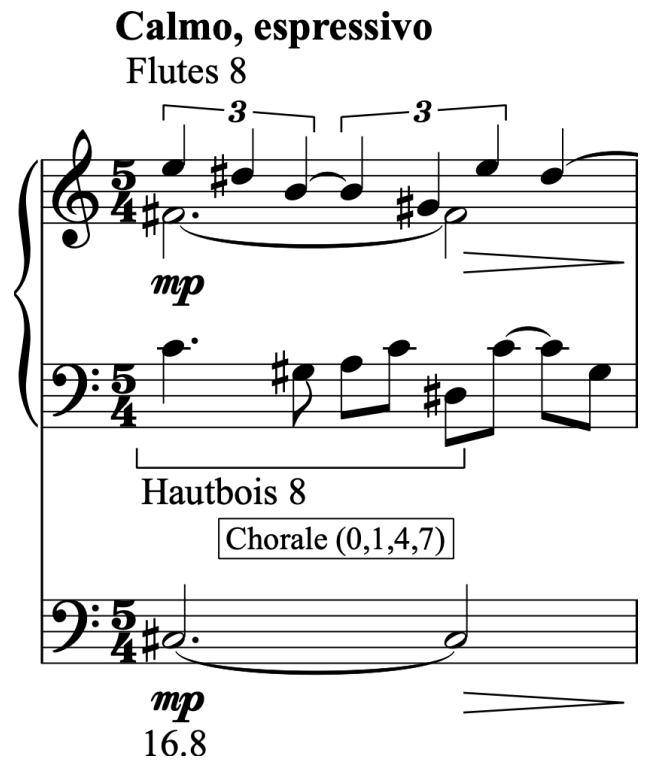

Example 15 - Organ solo part. $\mathbf{m} 9$

Another elaboration appears yet again when Chorale is expanded with a half step from the uppermost pitch in the $[0,1, \mathrm{x}, \mathrm{x}]$ set, seen in Example 16. It is closer to the first appearance of the Chorale in that it has the $[0,1,6]$ first but also include the [7] at the end similar the first development of the Chorale from measure 9 for a total of $[0,1,6,7]$. These intervallic relationships, or pitch-class sets, are what bind the Chorale melody and Chord 1 together. If the Chorale has a connection to the building blocks of Chord 1, then it seems likely that the orchestrally synthesized Chord 2 that appears in between the Chorales would be as well. 


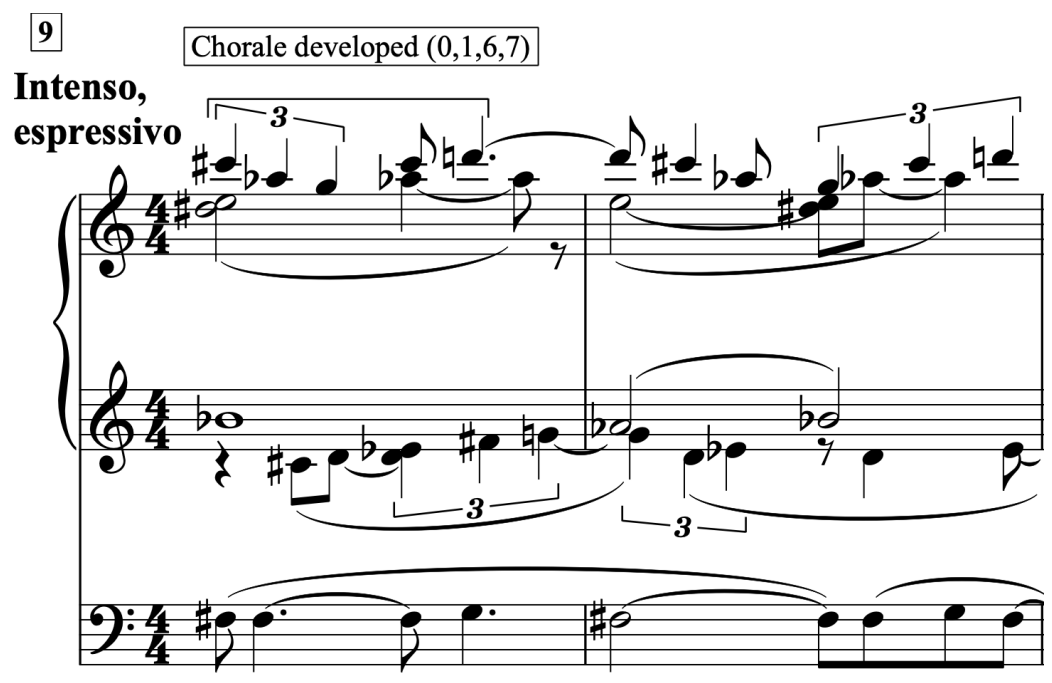

\section{Example 16 - Organ solo part, mm 22-23}

\section{Chord 2}

One problem that has arisen in analyzing "Dome" is that the chord that appears in measure 4 is difficult to perceive. The strings move from normal position to sul ponticello and finally sul tasto, making it difficult to pinpoint their exact pitches due to the noisy elements that is added as a result of these techniques. The registration for the organ calls for flute celestes, pipes that are tuned slightly sharp and paired with pipes in concert tuning to cause beating. ${ }^{78}$ The winds, large log drum, and timpani are playing tremolo and some are performing multiple pitches with a glissando between. Since most of the pitches are doubled by another instrument along with a solitary strike on the tamtam, it creates a timbre that is challenging and interesting. It may be the clearest example of orchestral synthesis in the work as the total sound of all the instruments creates a unique timbre.

\footnotetext{
${ }^{78}$ Please see Appendix 2 for more information.
} 
A nearly identical chord appears at the end of the movement as shown in Example 17. The percussion are the same as in the chord found in measure 4 though with the addition of the bass drum. The strings are on the same pitches, but transition from sul ponticello to sul tasto without beginning in a normal bowing position. The harp is added and doubles pitches in a tremolo. The three wind instruments are doing similar effects as the beginning chord but on different pitches in the chord. The most important distinction between the two versions of Chord 2 is in the organ part also seen in Example 17. In general, the second version of Chord 2 has more non-pitched, noisy elements than the first.
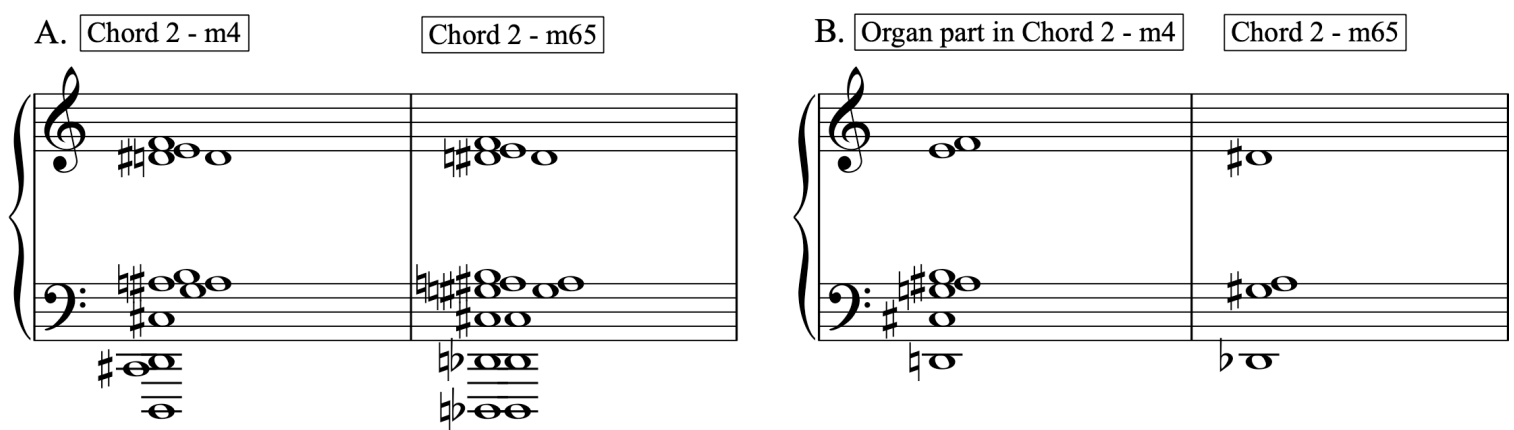

Example 17 - Written and sounding pitches of Chord 2, A, and pitches written for the organ, $B$.

The problem with Example 17 is that the sum total of pitches does not tell the whole timbral story. As set out above, the general timbre of the instruments includes some noisiness through extended techniques, tremolo, and very quiet dynamics. The one instrument that does not vary in its pitch, dynamic, and timbral quality is the organ and its registration of flute celeste. If the organ is the most consistent instrument in both versions 
of Chord 2's texture, its pitches are prominent in the texture of Chord 2. In both instances of Chord 2, the pitches of the organ make the $[0,1, x]$.

Example 18 shows a side-by-side comparison of the uppermost pitches in the organ part, the manuals, of Chord 2 as well the pitches of the Chorale melody. Between Example 18A and Example 18B, it is striking to see the half step similarity. The Chorale melody is made expressly of $[0,1,7]$ and is also contained in Example $18 \mathrm{~A}$ between E4, F4, and A\#3. The set $[0,1,7]$ is also in Chord 2, as shown in Example 18C, though its disposition is different than the other two.
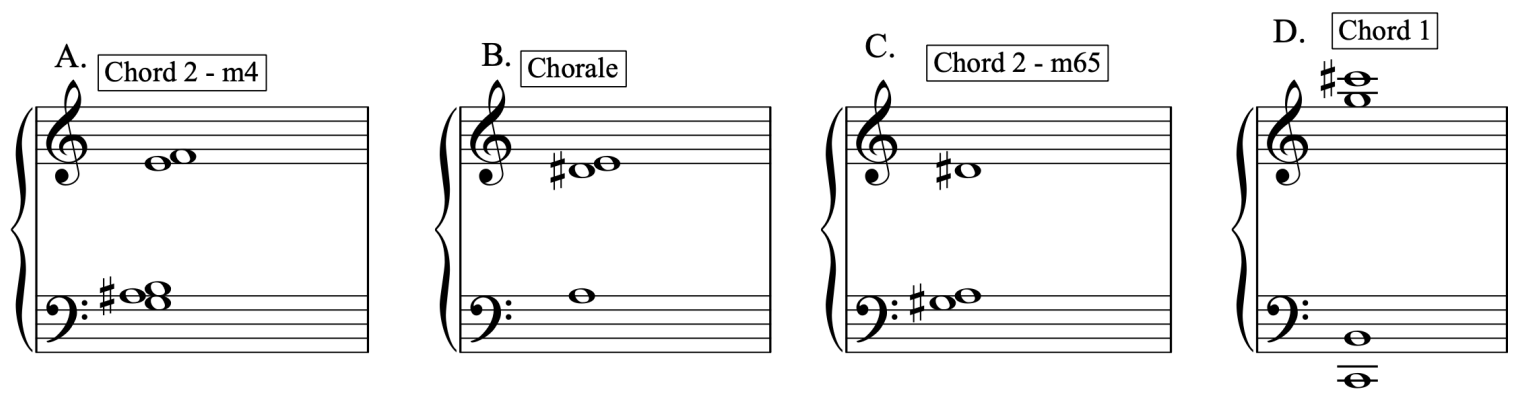

\section{Example 18 - Uppermost pitches of Chord 2 (A), with a comparison to three pitches} of the Chorale melody (B), the uppermost pitches in the ending Chord 2 (C), and Chord 1 (D).

There are a few commonalities between Chord 2 and Chord 1, shown again in Example 18D. The first is through their common building block of $[0,1, \mathrm{x}]$ and, in the specific case of the Chorale melody and Chord 2, $[0,1,7]$ which can be derived from Chord 1. Comparing Chord 1 with Example 17 above, there is a major $7^{\text {th }}$ interval that is common between the two in the lowest voices. Chord 2 does seem to be orchestrally synthesized, but the general timbre of the total pitches and their general tessitura being 
closer is quite different in comparison to Chord 1 with the tremolos and glissandos across the instrumentation.

When aesthetically similar chords to Chord 2 are played by the strings and organ tremolo, in measures 8 and 13, the upper voices of each of these chords are accented by the Chorale melody in various solo instruments. This stays generally true in the second half of the work as the Chorale and Chord 2 trade places once again after the ascent and descent in the middle portion of the movement. This development shows how Chord 2 and the Chorale are connected and the importance of the $[0,1, \mathrm{x}]$ to this movement as it relates to the other parts of Maan Varjot.

\section{Descent Figure}

Approximately halfway through the movement, a descending series of chords, which will be called the Descent Figure, appears in the organ solo part. A longer Descent Figure appears in the organ part at Rehearsal Mark 10, measure 42, as well as in the winds immediately afterward in response and augmentation. The Descent Figure, Example 19, from the organ solo part is generally characterized by the $[0,1, \mathrm{x}]$ building block, but not exclusively. 


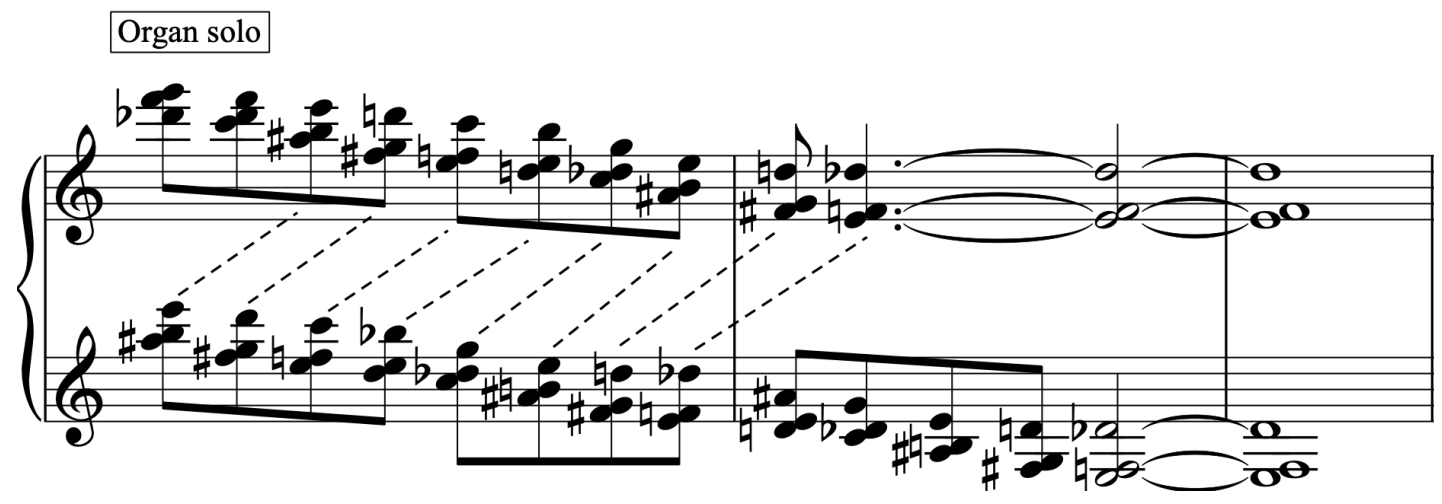

Example 19 - Descent Figure, mm 42-44

In the context of the organ part, the $[0,1, \mathrm{x}]$ and the occasional addition of the $[0,2, \mathrm{x}]$ is complicated by the overlapping as seen in the notation in Example 19. What is clear is the inclusion of a canonical element. The right hand is in imitation of the left hand. In measure 44, the winds and pitched percussion imitate the organ and then state the figure one last time in augmentation before measure 46. The Descent Figure appears one last time in the left hand of the organ part in measure 47. While the Descent Figure finishes in the organ in measure 44, the orchestra repeats the same figure in the winds and percussion. This includes the canonic element between the winds and the vibraphone. The Descent Figure appears again in the orchestra in measure 45 in augmentation.

Before the Descent Figure is heard, it is preempted by a descending motif in the organ and percussion in measures $30-36$, later accented by the strings in measures $32-35$ and trumpets, French horns, and trombones in measures 35 and 36 . The figure descends with $[0,1,6]$ using a registration of an $8^{\prime}, 11 / 3^{\prime}$ and the tremolo, a stop that gives the pipes a steady vibrato. This particular figure does not seem to have a strong aesthetic connection to the Descent Figure other than the use of the $[0,1, \mathrm{x}]$ building block. But this 
figure plays a small but important part in announcing the Descent Figure and it comes back in the third movement.

\section{The Dome}

"Dome" has some similarities to the first movement, "Earth's Shadows." Both share a similar reflective arch form, though execution of each arch form is distinctly different. In fact, the arch in "Dome" can be thought of as more of a perceptive arch than a formal one. The first movement used its light and shadow in the orchestration between the organ and the orchestra to show contrast with foreground and background material. In "Dome," the reflections of the "many-coloured glass" are portrayed antiphonally between the Chorale melody and texture and Chord 2 mixed with the Descent figure. The antiphony is explicit in the beginning, but within the first minute (around 10 measures), the Chorale and Chord have already begun to blend into one another, the colors of the glass overlapping one another (Example 20).

\begin{tabular}{|c|c|c|c|c|}
\hline Macro & Time & $\begin{array}{l}\text { Measure } \\
\text { Number }\end{array}$ & $\begin{array}{l}\text { Tempo and } \\
\text { Rehearsal Mark }\end{array}$ & Description \\
\hline \multirow[t]{4}{*}{$\bar{A}$} & $0: 00$ & Mm1-3 & $\begin{array}{l}\text { Lento, calmo; } \\
\mathrm{q}=\text { c. } 48-54\end{array}$ & $\begin{array}{l}\text { Introduction of the Chorale with the } \\
\text { melody soloed in the soprano voice of the } \\
\text { organ in a general polyphonic texture } \\
{[0,1,7] ; \mathrm{Db} \text { is the lowest pitch. }}\end{array}$ \\
\hline & $0: 14$ & M4 & Misterioso & $\begin{array}{l}\text { Chord } 2 \text { for a single measure; pitch } \\
\text { material difficult to discern; upper most } \\
\text { pitches form }[0,1,6,7] \text {; D is the lowest } \\
\text { pitch. }\end{array}$ \\
\hline & $0: 29$ & Mm5-7 & Calmo, espressivo & $\begin{array}{l}\text { Slight modulation of the Chorale, solo } \\
\text { voice still in soprano of the organ solo; } \\
\text { G\# and A are the lowest pitches. }\end{array}$ \\
\hline & $0: 47$ & M8 & Misterioso & $\begin{array}{l}\text { Chord } 2 \text { modulated and includes the } \\
\text { melody from the Chorale; general pitch } \\
\text { material is still difficult to perceive but } \\
\text { the highest pitches are accented by the } \\
\text { Chorale melody in }[0,1,6] \text {; B is the lowest } \\
\text { pitch. }\end{array}$ \\
\hline
\end{tabular}




\begin{tabular}{|c|c|c|c|c|}
\hline & $0: 59$ & M9 & Calmo, espressivo & $\begin{array}{l}\text { Chorale appears a third time in the organ } \\
\text { alone; melody includes an additional note } \\
\text { soloed in the tenor voice; C\# is the lowest } \\
\text { pitch. }\end{array}$ \\
\hline & $1: 06$ & Mm10-12 & & $\begin{array}{l}\text { Chorale continues in two solo violin parts } \\
\text { over the top of the Chord } 2 ; \text { the Chorale } \\
\text { and Chord } 2 \text { have begun to blur. }\end{array}$ \\
\hline \multirow[t]{9}{*}{$\mathrm{B}$} & $1: 20$ & Mm13 & $\begin{array}{l}\text { Sempre lento ma } \\
\text { intense; RM } 8\end{array}$ & $\begin{array}{l}\text { Chord } 2 \text { modulation with the same } \\
\text { pitches of the melody from the violin } \\
\text { solos now in the trumpets; Chord } 2 \text {. }\end{array}$ \\
\hline & $1: 29$ & Mm14-17 & & $\begin{array}{l}\text { Chorale in the organ accompanied by the } \\
\text { strings; cellos and double basses are } \\
\text { using non-equal, glissando half steps. }\end{array}$ \\
\hline & $1: 48$ & M18 & & $\begin{array}{l}\text { Chord } 2 \text { transposed again; Chorale from } \\
\text { the organ in previous measures bleeds } \\
\text { over. }\end{array}$ \\
\hline & $1: 55$ & Mm19-21 & & $\begin{array}{l}\text { The full polyphonic Chorale in the horns } \\
\text { and trumpets; first time outside of the } \\
\text { organ; low quarter steps in the bassoons. }\end{array}$ \\
\hline & $2: 11$ & M22 & & $\begin{array}{l}\text { Chord } 2 \text { again; Chorale bleeds over from } \\
\text { the brass; quarter steps transferred from } \\
\text { the bassoons back to cellos and double } \\
\text { basses. }\end{array}$ \\
\hline & $2: 16$ & $\mathrm{Mm} 23-28$ & $\begin{array}{l}\text { Intenso, } \\
\text { espressivo; RM } 9\end{array}$ & $\begin{array}{l}\text { Polyphonic Chorale in the organ } \\
\text { accompanied by cellos and double basses } \\
\text { in quarter steps similar to mm 14-17; } \\
\text { Chorale modulates upward. }\end{array}$ \\
\hline & $2: 45$ & M29 & Dolce & $\begin{array}{l}\text { The Chorale again carries over into } \\
\text { another transposition of Chord } 2 ; \text { this } \\
\text { permutation of Chord } 2 \text { includes } \\
\text { quintuplets and sixteenths. }\end{array}$ \\
\hline & $2: 52$ & Mm30-37 & Espressivo & $\begin{array}{l}\text { A descending figure in the organ and } \\
\text { pitched percussion; Chorale is first in the } \\
\text { trumpets and then the piccolo }\end{array}$ \\
\hline & $3: 29$ & Mm37-41 & $\begin{array}{l}\text { Poco a poco più } \\
\text { grave }\end{array}$ & $\begin{array}{l}\text { Chorale in the French horns; quote from } \\
\text { "Earth's Shadows" in the low brass and } \\
\text { organ (quote from the beginning of the B' } \\
\text { organ pitches). }\end{array}$ \\
\hline \multirow[t]{3}{*}{$\mathrm{C}$} & $3: 56$ & Mm42-45 & RM 10 & $\begin{array}{l}\text { Descent Figure in the organ; repeated by } \\
\text { the winds and pitched percussion; } \\
\text { repeated a third time in augmentation by } \\
\text { the winds. }\end{array}$ \\
\hline & $4: 18$ & $\mathrm{Mm} 46-49$ & $\begin{array}{l}\text { Grave, intense (ma } \\
\text { senza accel.) }\end{array}$ & $\begin{array}{l}\text { The winds are in unison on the Chorale } \\
\text { melody; accompanied first primarily by } \\
\text { the organ and violins; the Descent Figure } \\
\text { in the left hand of the organ is followed } \\
\text { by a quote of "Earth's Shadows" with the } \\
\text { low brass similar to the one in mm39-41. }\end{array}$ \\
\hline & $4: 43$ & Mm50-52 & Più dolce & $\begin{array}{l}\text { Return of the Chorale in the organ } \\
\text { primarily accompanied by the horns and } \\
\text { trumpets. }\end{array}$ \\
\hline
\end{tabular}




\begin{tabular}{|l|l|l|l|l|}
\hline & $4: 59$ & M53 & & $\begin{array}{l}\text { Another permutation of Chord 2 similar } \\
\text { to m29. }\end{array}$ \\
\hline A' $^{\prime}$ & $5: 06$ & Mm54-56 & Calmo; RM 11 & $\begin{array}{l}\text { Chorale in the organ using the same pitch } \\
\text { material as A' in different voices; Chord } \\
\text { 2 sustained over from previous bar. }\end{array}$ \\
\hline & $5: 21$ & M57 & & $\begin{array}{l}\text { Chord 2 with quintuplets and sixteenth } \\
\text { notes; Chorale melody in the English } \\
\text { horn. }\end{array}$ \\
\hline & $5: 28$ & Mm58-59 & & $\begin{array}{l}\text { Chorale in the organ a half step lower } \\
\text { than the previous statement at mm54-56; } \\
\text { also related to the Chorale in mm5-7; } \\
\text { strings sustain through the previous } \\
\text { Chord 2 and into the next Chord 2. }\end{array}$ \\
\hline & $5: 39$ & Mm58-59 & Misterioso & $\begin{array}{l}\text { Chord 2 in quintuplets and sixteenth } \\
\text { triplets; Melodic fragments from the } \\
\text { Chorale in the oboe and trumpet. }\end{array}$ \\
\hline & $5: 52$ & Mm62-64 & Molto Calmo & $\begin{array}{l}\text { Exact restatement of the opening 3 } \\
\text { measures. }\end{array}$ \\
\hline $6: 13$ & & $\begin{array}{l}\text { Lentissimo; Dolce, } \\
\text { misterioso }\end{array}$ & \begin{tabular}{l} 
Near restatement of Chord 2 from M4. \\
\hline
\end{tabular} \\
\hline
\end{tabular}

Example 20 - Detailed overview of "Dome"

In the detailed analysis in Example 20, the general back and forth between the Chorale and Chord 2 can be seen, as well as the how the two overlap one another. While the general form is marked, A-B-C-A, what is missing in this analysis is the perceptual aspects of the movement. After three antiphonal statements of the Chorale and Chord 2, Rehearsal Mark 8 marks the beginning of the development of the Chorale. The $[0,1,6]$ of the Chorale melody is added to and changed while gradually ascending in pitch. Antiphony continues with Chord 2 and the Chorale, though they are often blended together. This gradual ascent happens in terms of general pitch tessitura, particular to the Chorale. The descent happens in a similar manner with the addition of the Descent Figure. From measure 46, where the Chorale melody is heard mostly in unison in the winds, the Chorale gradually descends from a generally higher register back to measure 62 where it appears as it did in the beginning. "Dome," in its perceivable arch form, is 
shown in Example 21. The Example includes lines to show the relationship between sections at the beginning and ending. They are not necessarily or exactly correlated to one another, but to show the how perceptible arch relates at the beginning and end.

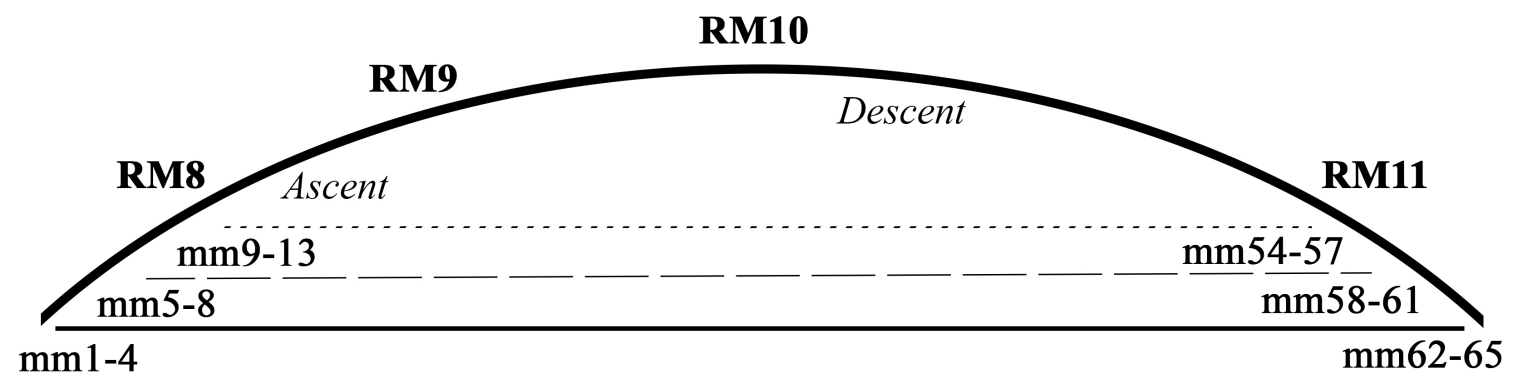

\section{Example 21 - Ascent and descent in "Dome"}

A couple of details need to be expanded upon that anticipate, enhance, and subvert the general form. The first is the inclusion of a quote from "Earth's Shadows." In the $\mathrm{B}^{\prime}$ section of the first movement, the organ part has background material that gradually builds from its lowest pitches to very high pitches. This is quoted in the organ and low brass in measures 39-41. Examples 22 and 23 show a side-by-side comparison of the two moments. Another ascending figure very reminiscent of this appears in measures 48 and 49 . This second moment ends with the organ playing something very similar to the Elaboration Chord. 


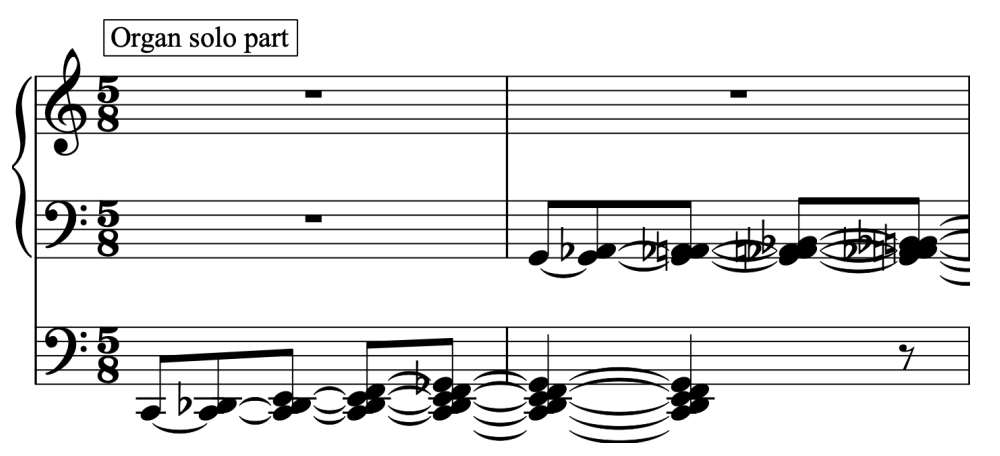

Example 22 - "Earth's Shadows," Organ solo part: mm 82-32

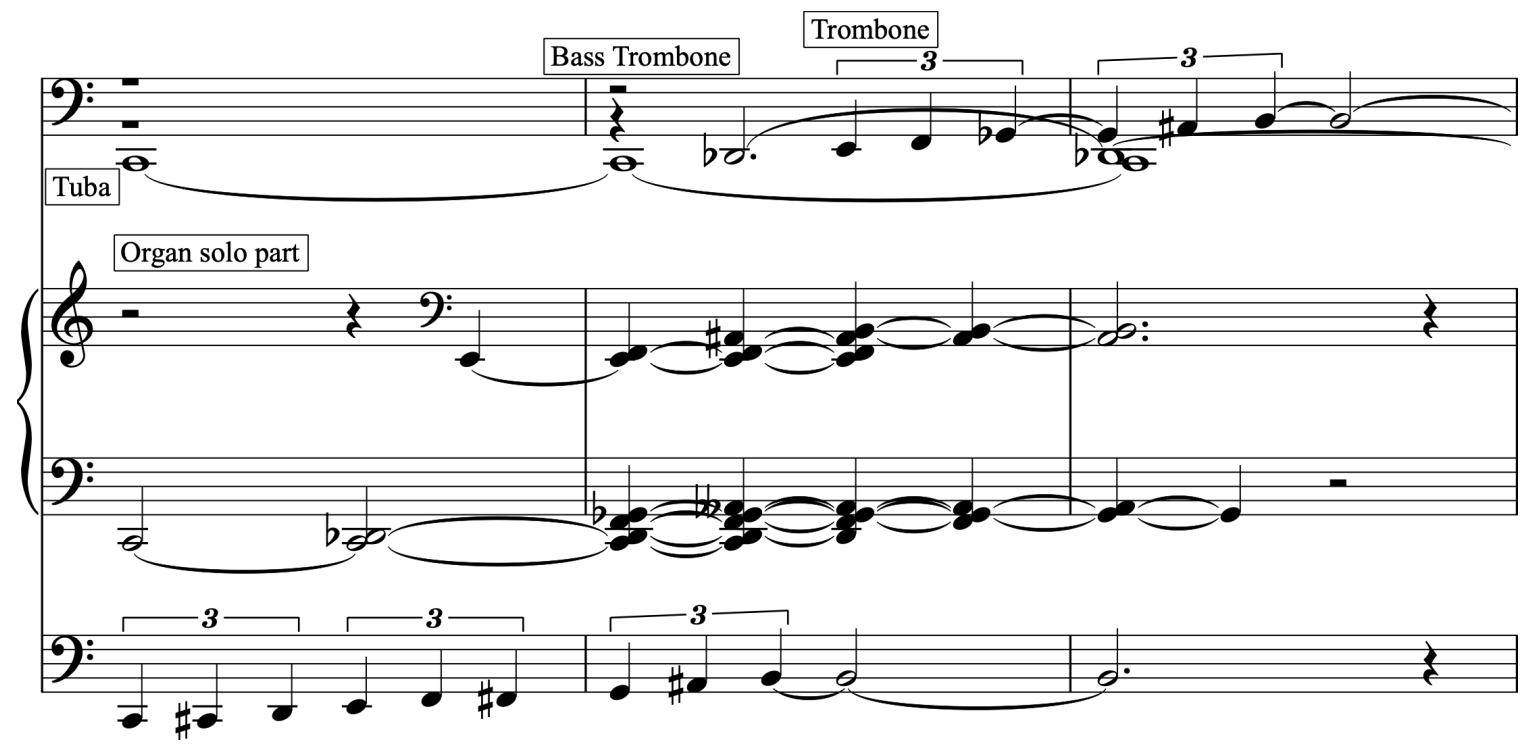

Example 23 - "Dome," organ and low brass, mm 39-41

It is interesting that these moments happen around the Descent Figure. If Saariaho is using the poem as her inspiration, and "Dome" is either about the movement of the sky from dawn to dusk or sunshine moving through stained glass, it makes sense that the first movement would be quoted. The ascending materials presented in the background of "Earth's Shadows" appear as shadows in the "Dome." Another connection that "Dome" has to "Earth's Shadows" is a figure similar to Example 8A. In measure 17, an Ab is 
introduced in the crotales followed by the other mallet percussion in octaves. The harp also plays an $\mathrm{Ab}$ in a triplet figure that is reminiscent to what the harp plays in Example $8 \mathrm{~A}$. There is even a $\mathrm{G}$ included in measure 20 , showing the strong similarity to what is found in the foreground figure from "Earth's Shadows." This figure appears in the harp and percussion again in measures $53,57,58$, and 59 . Based on the analysis of the first movement, this figure is a part of the foreground material. Saariaho seems to be including the light and shadow of the first movement as a part of the "Dome." Since Saariaho used motifs and themes from "Earth's Shadows" in "Dome," it should be no surprise that she continued this approach in the final movement, "Flowers, ruins, statues." 


\section{Part 3 - III. Flowers, ruins, statues}

"Flowers, ruins, statues, music, words, are weak The glory they transfuse with fitting truth to speak."

The final movement of Maan Varjot is the most complex. But here, again, the title gives imagery that helps in the analysis of the movement. The form of the movement may be thought of in three parts, as the title has three words. Each of those sections seems to be related to those words, but it is less clear than the other two movements. There is also the continued use of the $[0,1, \mathrm{x}]$ building block of Chord 1 found in the first movement, and the Chorale from the second. In "Flowers, ruins, statues," Saariaho continues using these materials in a new and unique way. The new aspect that is unique to this movement needs to be defined first: the French toccata.

\section{Toccata Figure}

The movement begins with what I have labeled 'the Toccata Figure.' The term toccata is derived from the Italian word toccare meaning 'to touch.' As a part of the literature for keyboard and organ, it refers to music that is not related to dance but is free in form and a way to showcase a performer's talent. In the $19^{\text {th }}$ century, the term was chosen by French organists "for the brilliant finales of their organ symphonies."79 Perhaps the most well-known toccata from this era of the organ literature is Charles Marie Widor's “Toccata” from his Fifth Organ Symphony. In Widor's piece, the part for the manuals is characterized by a repetitious, quick figure, primarily in sixteenth notes

\footnotetext{
79 John Caldwell, "Toccata," Grove Music Online. 2001; Accessed 25 Mar. 2020, https://www-oxfordmusiconlinecom.www.libproxy.wvu.edu/grovemusic/view/10.1093/gmo/9781561592630.001.0001/o mo-9781561592630-e-0000028035.
} 
with accompanying eighth notes (Example 24). Another example of this kind of writing is Eugène Gigout's "Toccata" from 10 Pièces pour orgue. Again, there is a repetitive figure characterized by sixteenth notes (Example 25). For both of these examples, the sixteenth note figures do not stop until the very end of each piece, creating a moto perpetuo aspect to the toccata.

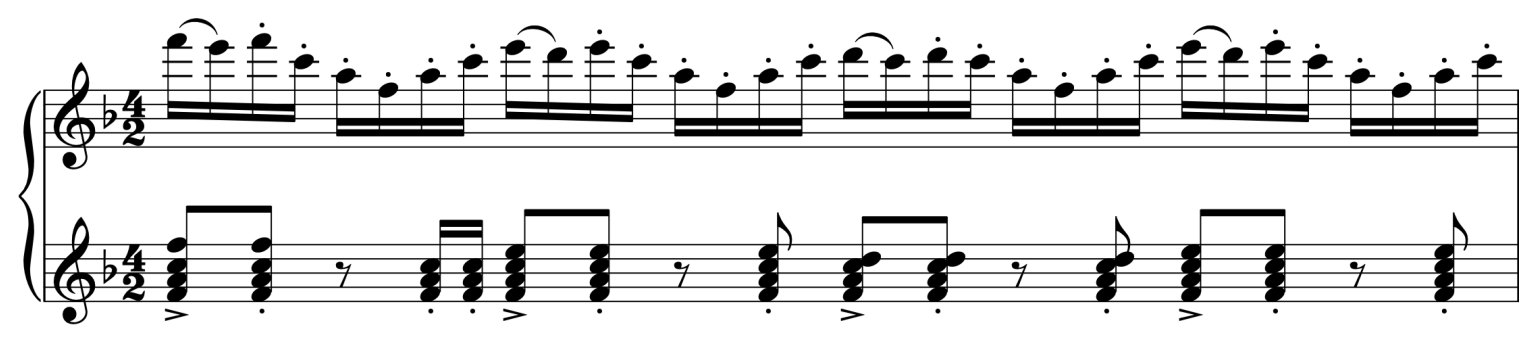

Example 24 - Charles Marie Widor's Toccata from Fifth Organ Symphony

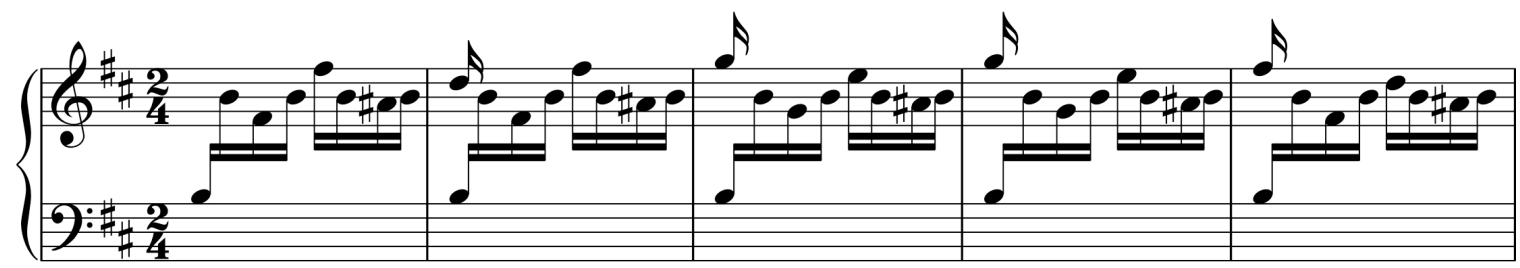

Example 25 - Eugène Gigout's Toccata from 10 Pièces pour orgue

As one final example, Charles Tournemire's "Toccata" from his Suite de morceaux, Opus 19, shows another way to demonstrate the moto perpetuo element in the organ toccata. In Example 26, the opening four measures have a typical running sixteenth note pattern, similar to the first two examples. In Measure 5, though, the pattern is different, as it has the continual moto perpetuo sixteenth notes occurring over the entirety of the hands rather than a single sixteenth note pattern. This moto perpetuo is seen in many of the toccatas of the $19^{\text {th }}$ and $20^{\text {th }}$ century French tradition. These three examples 
were chosen to demonstrate the variety in realizing a toccata figure. The Widor example has the moto perpetuo all in one hand whereas the Gigout example has it between both hands. The Tournemire example shows the moto perpetuo as a mixture of both beginning in the fourth full measure. For the purposes of this paper, when the word toccata is used, this is meant to refer to this kind of musical figure.
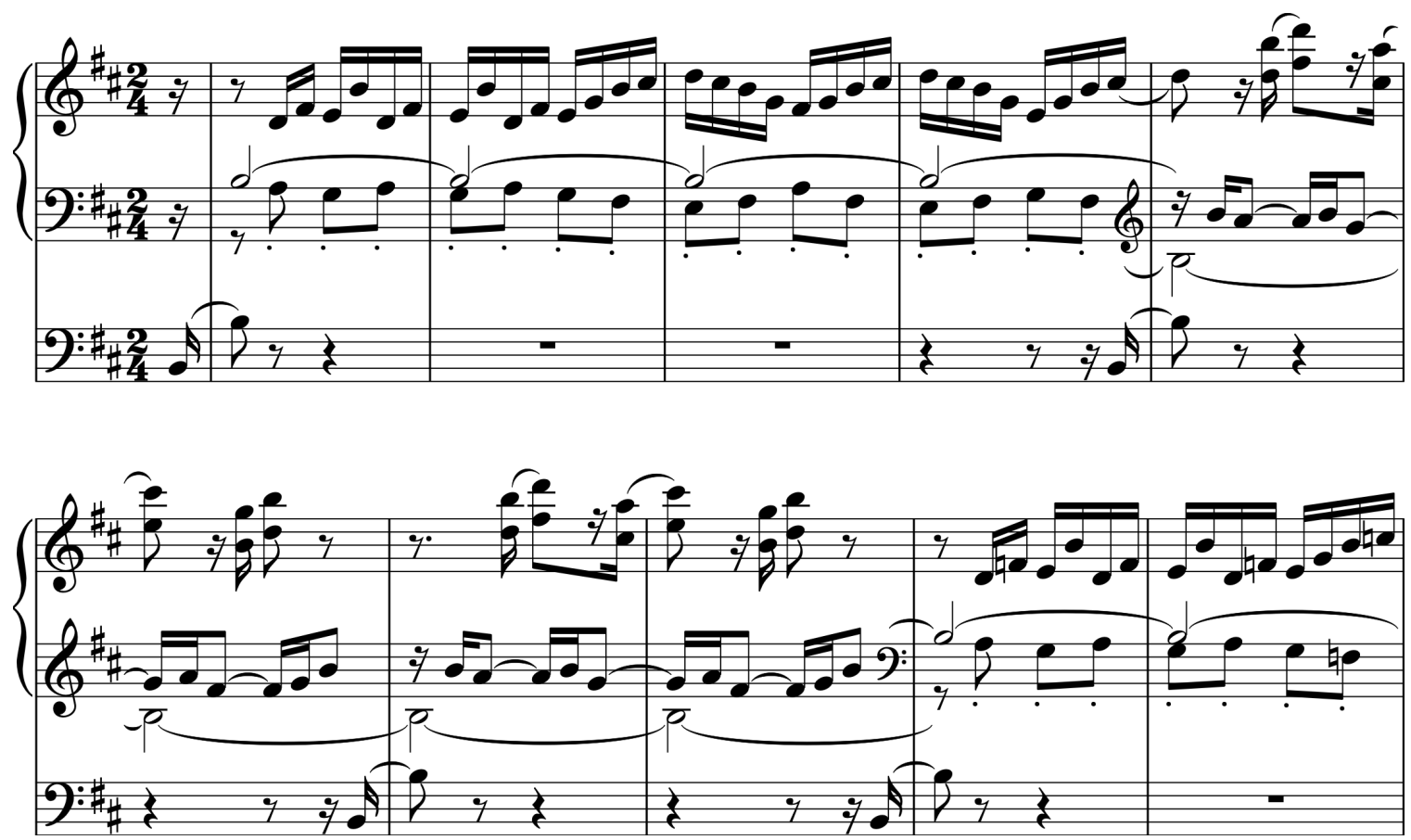

Example 26 - Charles Tournemire's Toccata from his Suite de morceaux

"Flowers, ruins, statues," sees the organ and orchestra regularly using the Toccata Figure. At the beginning of the movement, the organ has fast moving notes in a somewhat regular pattern in the French toccata tradition (Example 27). Latry commented that the organ part in this movement was reminiscent of one of his improvisations at 
Notre-Dame during one of Saariaho's visits. ${ }^{80}$ This is unsurprising as toccatas are a usual "sortie" or exit to a liturgical service as well as part of an organ suite, sonata, or symphonic composition. ${ }^{81}$

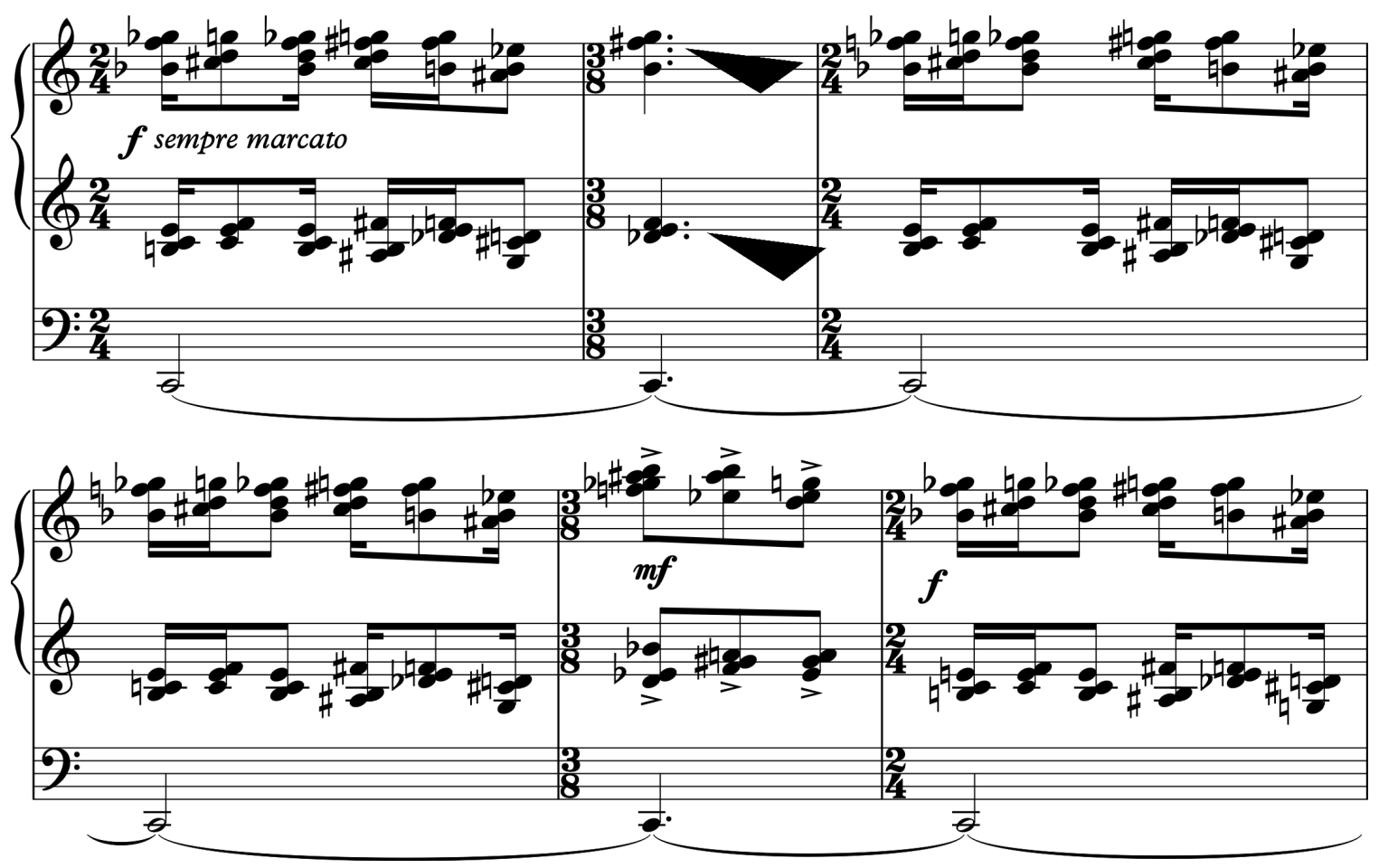

Example 27 - Organ solo part mm1-6

There is an aspect to the Toccata figure that relates the pitch material found throughout the work. Each of the individual chords in either hand fit into the $[0,1, \mathrm{x}]$ or $[0,1, \mathrm{x}, \mathrm{x}]$ pointing to its connection to the building blocks found within Chord 1 . This

80 "Esa-Pekka Salonen, Kaija Saariaho and Olivier Latry introduce Saariaho's Maan varjot," Philharmonia Orchestra, Youtube video, 08:06, June 12, 2014, https://www.youtube.com/watch? $v=$ p4lfQy-ImhY and Olivier Latry in discussion with the author, October 18, 2018.

${ }^{81}$ John Caldwell, "Toccata," Grove Music Online. 2001; Accessed 25 Mar. 2020, https://www-oxfordmusiconline-

com.www.libproxy.wvu.edu/grovemusic/view/10.1093/gmo/9781561592630.001.0001/o mo-9781561592630-e-0000028035. 
aspect remains consistent throughout the movement, even when the Toccata Figure is orchestrated in various ensembles within the orchestra.

The opening of this movement has a pedal $\mathrm{C}$ for approximately the first 16 measures, a feature of Chord 1 at the beginning and end of "Earth's Shadows." The presence of other tones found in Chord 1 is noticeable. Chord 1 includes a B, G and C\# and the Toccata Figure dances around those pitches. The connection is especially strong when the recording of the Toccata is placed against Comparative Model. Between the pitch material and the auditory comparison, it seems likely that the Toccata Figure here at the beginning of "Flowers, ruins, statues" is related to Chord 1.

\section{Contrasting Motifs}

While French toccatas are repetitious, moto perpetuo-like figures, there are motifs that appear regularly in contrast to the near constant 16ths of the Toccata Figure of "Flowers, ruins, statues." A few consistent features can be found in what will be called the Contrasting Motifs, though they are not employed consistently throughout the movement. In general, these motifs use the $[0,1, \mathrm{x}]$ or $[0,1, \mathrm{x}, \mathrm{x}]$ building block melodically, but even that is inconsistent.

The use of syncopations, triplets, and trills are perhaps the most common and consistent element in the Contrasting Motifs. The first time these motifs appear as something not related to the Toccata Figure is in the organ solo part in measure 25, Example 28a. Other motifs similar to this one appear as well: in measures 29-30 in the organ, measures 54-55 in many of the flutes, oboes, English horn, and Eb clarinet, Example 28b, and measures 125-126 in the piccolo are three examples of this 
Contrasting Motif. Much like the Toccata Figure, these are built with the $[0,1, \mathrm{x}]$ building block. For example, the piccolo in Example 28c is $[0,1,4]$.

A) organ solo part, $\mathrm{mm} 29-30$

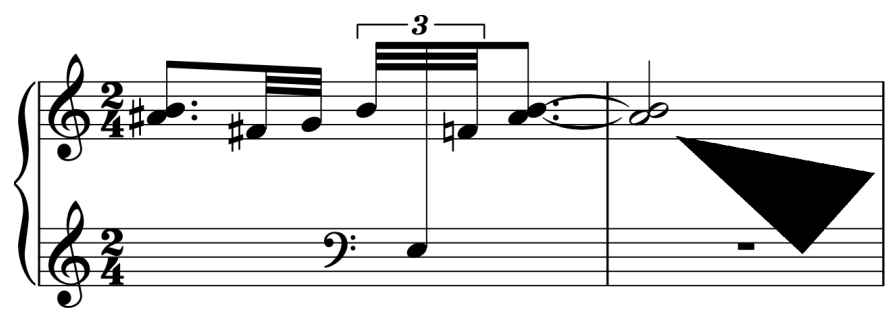

B) woodwinds, mm54-55

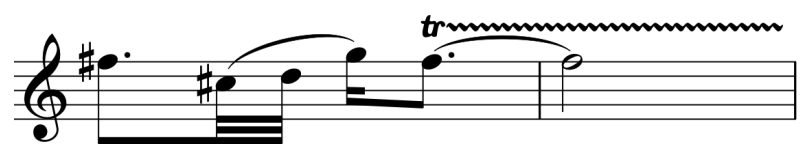

C) piccolo, mm125-126

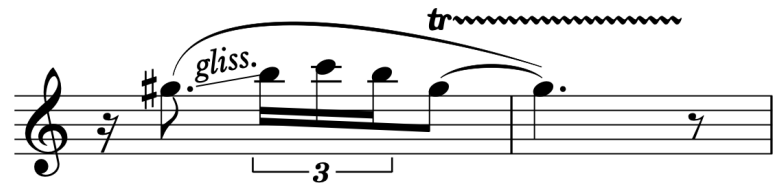

\section{Example 28 - Contrasting Motifs}

"Flowers, ruins, statues," does not strictly adhere to any consistent pattern with these Contrasting Motifs. After the organ performs a Contrasting Motif in measures 29 and 30 , it is immediately followed by similar sounding motifs in the brass and woodwinds. None of them are consistent in their rhythmic presentation. But as mentioned above, they do all work from the same general $[0,1, \mathrm{x}]$ and $[0,1, \mathrm{x}, \mathrm{x}]$ building block. 


\section{Three Chord Figure}

In "Flowers, ruins, statues," there is a three-chord figure that appears regularly throughout the entire movement. It first appears in measure 2 in the vibraphone and strings in pizzicato, and shortly thereafter in the organ and marimba in measure 5 (Example 29). Its importance to the work is partly as a structural element as it usually occurs adjacent to the toccata and is useful in performance as well, as Latry stated that these bars helped keep the orchestra together. ${ }^{82}$

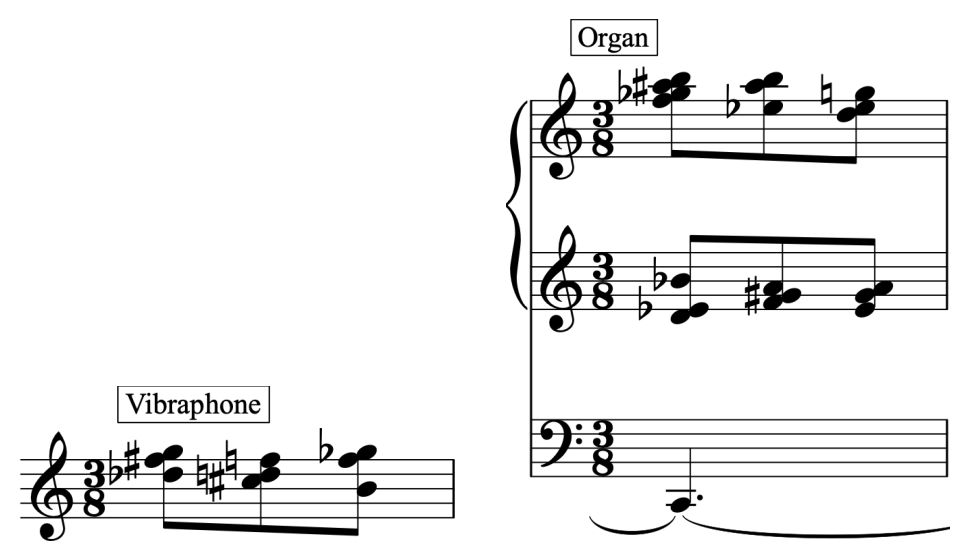

Example 29 - Vibraphone, $\mathrm{m} 2$ and organ solo part m5, left hand doubled by marimba

The Three Chord Figure also appears several times in augmentation. Example 30 illustrates the first occurrence in measures $21-23$. While the shorter $3 / 8$ bars appear with some regularity, the augmented Three Chord Figure appears only three additional times after this first one. The two forms of the Three Chord Figure do not show up as often as the Toccata Figure, but like the Tutti Toccata Figure, described below, play an important

${ }^{82}$ Olivier Latry in discussion with the author, October 18, 2018. 
role in the structure of the work and can act as guideposts to various sections of "Flowers, ruins, statues."

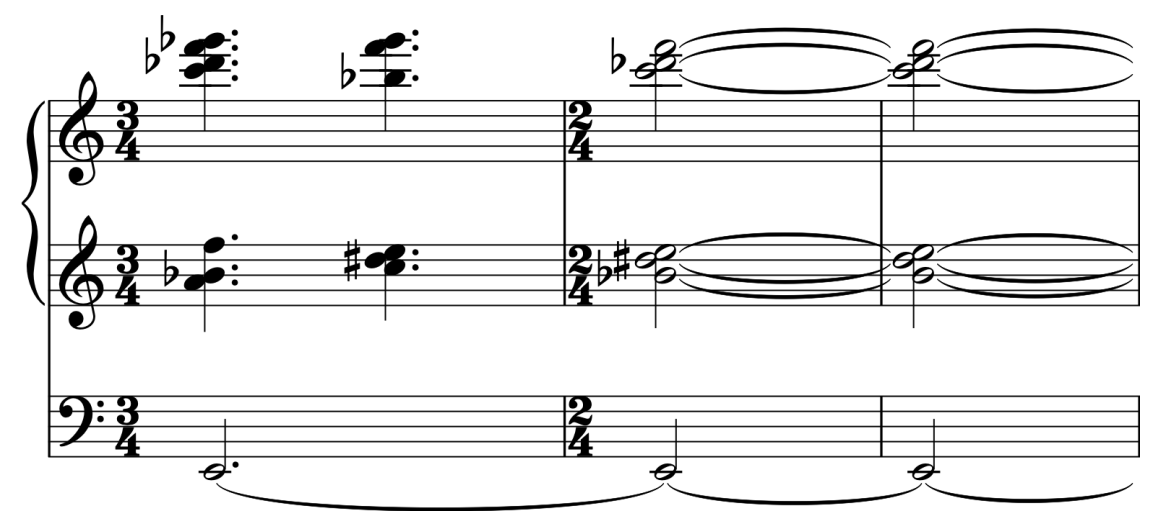

\section{Example 30 - Three Chord Figure, Organ solo part mm 21-23}

\section{Three Words from the Poem}

The title of the third movement comes from the penultimate line of the $51^{\text {st }}$ stanza and includes more words than are found in the title of the movement. Unlike the other two movements, I do not believe that the remainder of the line is helpful for the analysis. Where the poem and the movement seem to meet is at three particular moments where the orchestra performs the Toccata Figure in full or near full force, dividing the movement into three parts. Each of these parts end with similar textures: the first two times in full or near full orchestral tutti on the Toccata Figure and the last with the organ playing the same tutti Toccata Figure alone at the end of the movement.

What I will now call the Tutti Toccata Figure, is similar to the Toccata Figure as demonstrated above but in these moments of formal divide, it takes on distinct characteristics unique to those moments (Example 31). The first is that the Tutti Toccata Figure usually occurs in more than an individual section or in the solo organ part. While 
the Toccata Figure often has a pedal tone, these Tutti Toccata Figures have bass lines that oscillate by a half step in the syncopated toccata rhythm. This bass movement is related to the $[0,1, \mathrm{x}]$ building block. Lastly, the Tutti Toccata Figure only appears at important moments in the form of the work. This will be expanded upon below.

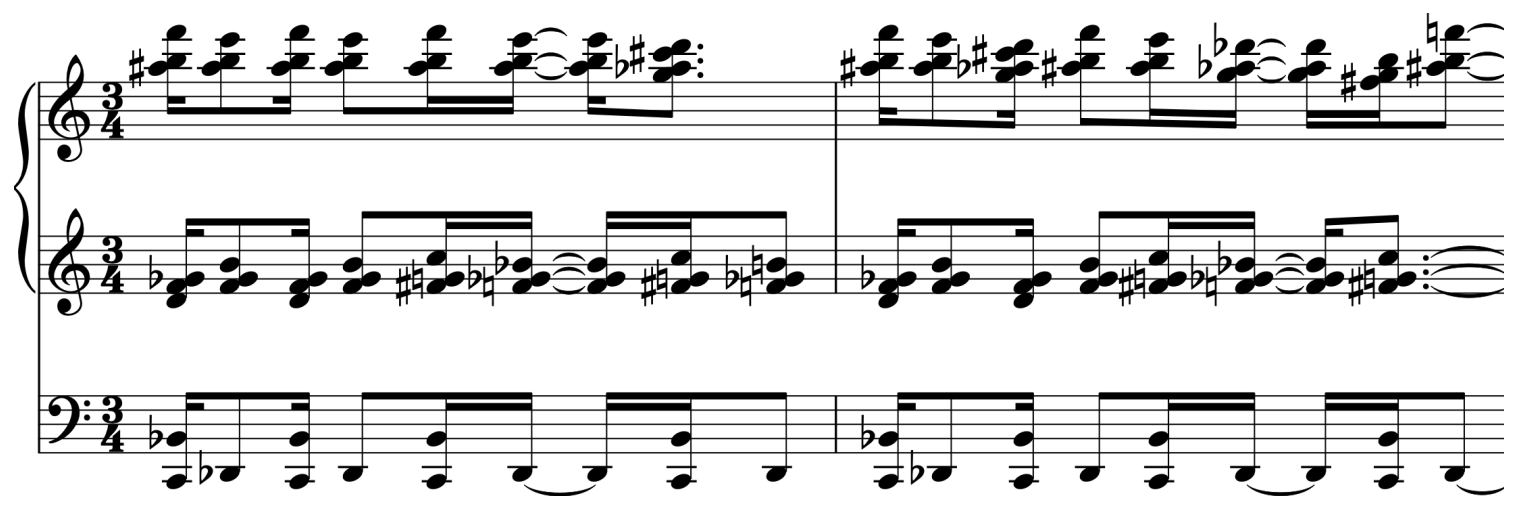

Example 31 - Tutti Toccata Figure in the organ solo part, mm105-106

There are textural elements that are different for each of the three sections of "Flowers, ruins, statues" as well, though they are related. Example 32 is a visualization of the form in relation to the three words used in the title. This general outline shows the intensity and dynamic of each section while also including the movement of the lowest pitches. Each of the sections ends with the Tutti Toccata Figure before moving to a new section, the most perceivable element in determining the form. The piece also ends with Chord 1 almost exactly as it appeared in the opening of Maan Varjot. It is only possible to discover this when listening to the work more than once in a single setting. 


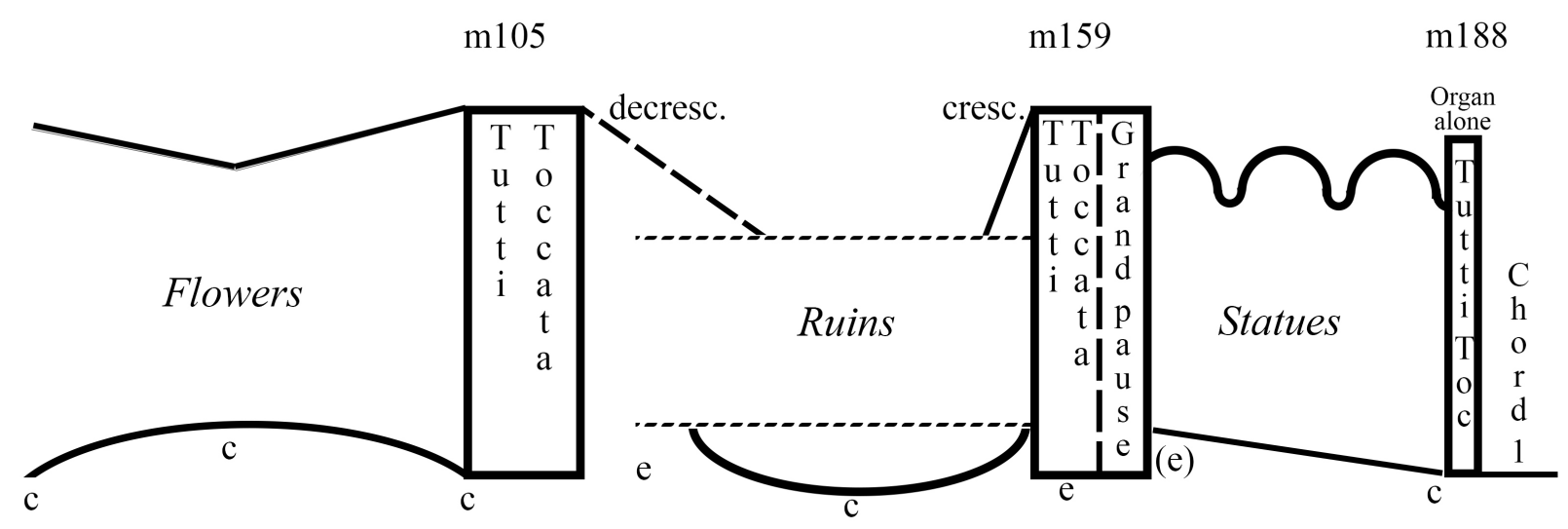

Example 32 - formal overview of "Flowers, ruins, statues"

There is also direction in the bass line that is unique to each section of "Flowers, ruins, statues" as reflected in the lowest line in Example 32. The most difficult section to discern is the beginning of the middle section as the first Tutti Toccata section gradually decrescendos without a clear end to the decay and a clear beginning to another section. The Grand Pause at the end of the second section, "ruins," makes a clear separation from the previous material. Even at the end of "statues," after the organ plays the Tutti Toccata Figure alone, it is followed by five hits on the bass drum; nearly a grand pause of its own before Chord 1 reappears.

One problem in the perception of the form for "Flowers, ruins, statues" is that the Tutti Toccata at the end of "Flowers" is much longer than any of other Tutti Toccatas. Upon the first few times experiencing the recording, it felt as though the high point of the movement occurred in the middle rather than the end. Example 33 is a decibel peak and spectrogram of the recording and shows some important features. First, it confirms the analysis of the form above: the piece is broken into three major sections and each section 
has its own arch. The spectrograph is included to show the differences in general intensity between the three sections of the movement. Secondly, it reveals a relationship between "Flowers" and "statues." "Flowers" and the first part of "statues" have similar spectrographs. More noticeable is the "ruins" spectrogram and the similarity it shares with its "statues" counterpart.

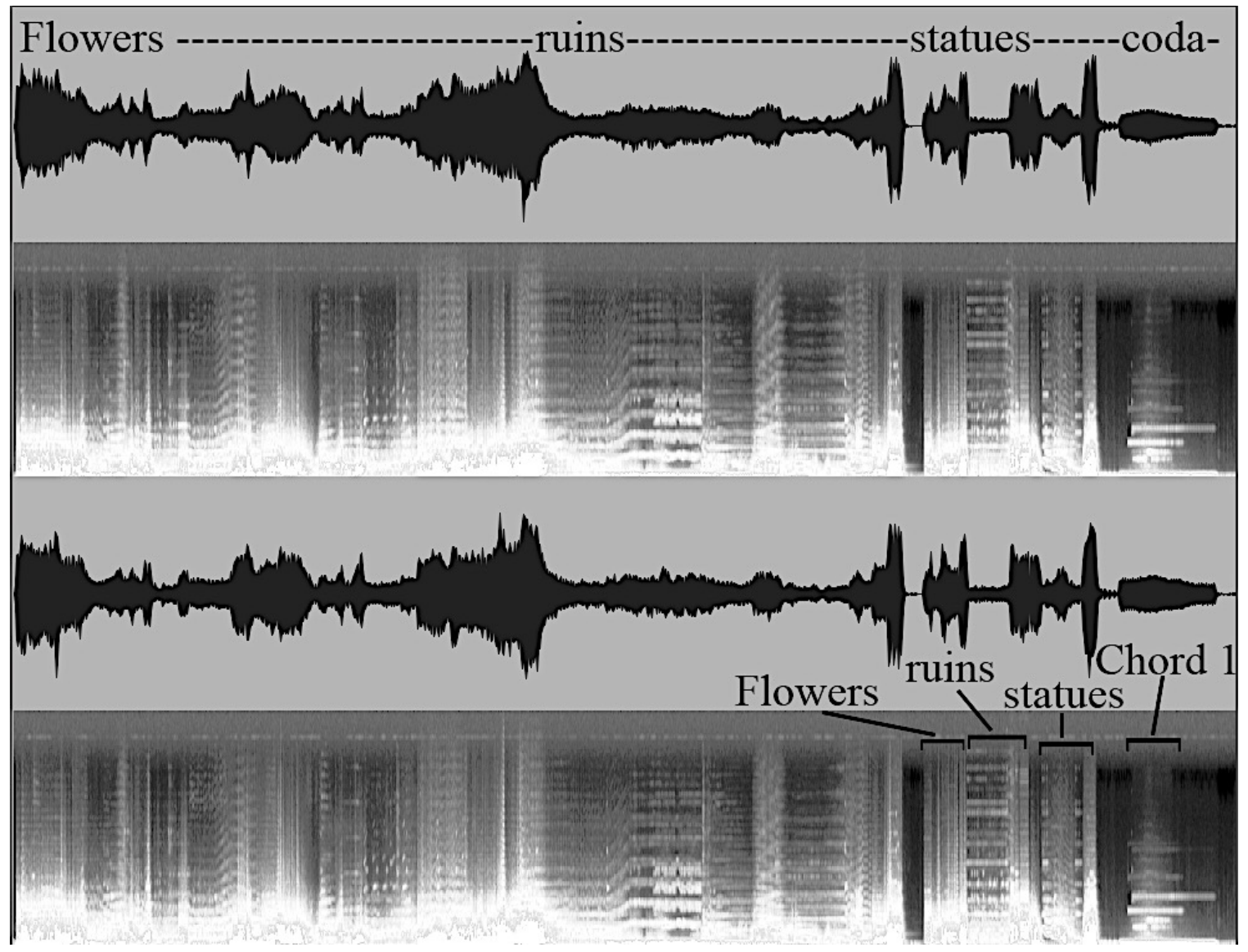

Example 33 - Decibel peaks and spectrogram of the recording for "Flowers, ruins statues"

If so much of the work is about reflections, light, and shadow, the connection this movement has with the work as a whole is not readily apparent. The first two movements 
concerned themselves more with two features that contrast and complement one another. In "Earth's Shadows" this was seen in the foreground and background material between the orchestra and organ developed from Chord 1. "Dome" has its Chorale and Chord 2 that play with one another antiphonally. But "Flowers, ruins, statues" has three sections with a Toccata Figure and the Three Chord Descent figure that seem to just happen in succession without much to connect them.

I believe that this movement is a reflection of Maan Varjot as a whole work. Each of the three sections is in some way a reflection or shadow of one of the three movements of the piece. If that is the case, the final section of the third movement would be reflective of the third movement, which itself is already a reflection. The difference in the third part, "statues," is that it reflects the movement itself. The spectrogram and decibel peaks chart in Example 33 are helpful in demonstrating this idea. There are three peaks in the first part of "statues," followed by a spectrogram that is similar to the middle "ruins" section, and the final section ends with Chord 1 , just as the piece began. The sections are not necessarily related to their movements respectively, but simply a reflection or shadow of the movement in the context of the finale movement as shown in Example 34. 


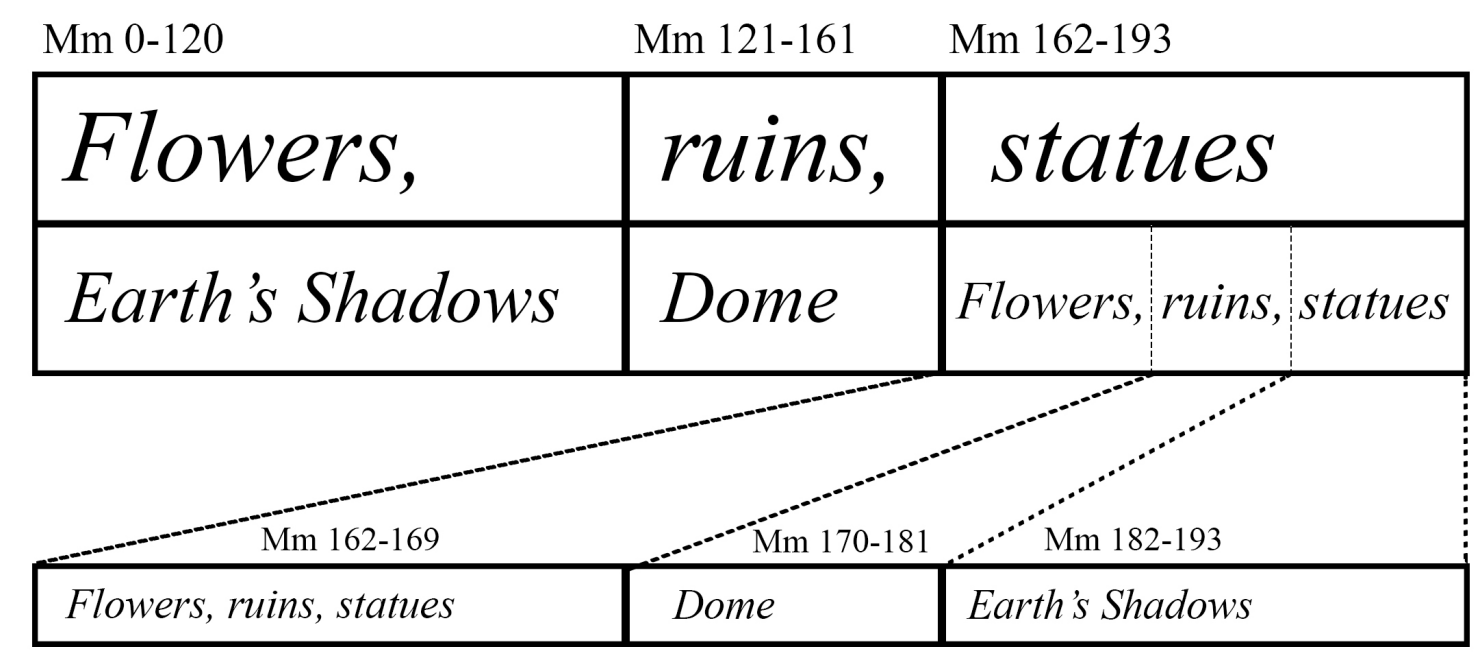

\section{Example 34 - Formal reflection in "Flowers, ruins, statues"}

The Tutti Toccata Figure at the end of each miniature section in the "statues," measures 162-193, further demonstrates the reflection. In measure 168, the Tutti Toccata Figure includes brass and is the most similar to the other Tutti Toccata Figures. The other two that appear at measures 180-181 and 188-189 are with the organ alone in a slight variant to the Tutti Toccata Figure. Since these only appear at the ends of sections, it seems as if Saaraiho is reflecting the work back upon itself.

I do not mean to suggest that the three various sections of "Flowers, ruins, statues" are identical or include exact quotations from their respective movements that they are reflecting. It is simply that they reflect elements of those movements in some manner. The first example of this reflection begins in the third section as the movement quotes itself. There is a clear parallel between measures 162-176 and earlier in the movement in measures 24-36. This is why I think that "Flowers, ruins, statues" is reflected first in the final section, rather than "Earth's Shadows." 
Another example of this reflection happens measure 182, Rehearsal Mark 22.

Three pitches are played and sustained in descending motion, a possible quote from

"Dome," measure 30, where the Descent Figure is preempted. Lastly, it is impossible to ignore the closing Chord 1, nearly identical to the opening of Maan Varjot and "Earth's Shadows." Example 35 below includes more detailed descriptions of the event for the whole movement as well as the how the interpretation of the form came to be. While some of these relationships may seem tenuous, it is the general three-part nature of the last section of "Flowers, ruins, statues" that informs how the piece ends.

III. Flowers, ruins, statues

\begin{tabular}{|c|c|c|c|c|c|}
\hline Macro & $\begin{array}{l}\text { Movement } \\
\text { Reference }\end{array}$ & Time & $\begin{array}{l}\text { Measure } \\
\text { Number }\end{array}$ & $\begin{array}{l}\text { Tempo and } \\
\text { Rehearsal Mark }\end{array}$ & Description \\
\hline \multirow[t]{8}{*}{ A (flowers) } & $\begin{array}{l}\text { Earth's } \\
\text { Shadows }\end{array}$ & $0: 00$ & Mm1-10 & Energico $\mathrm{q}=\mathrm{c} .88$ & $\begin{array}{l}\text { Toccata figure in the organ over a pedal } \\
\mathrm{C} \text {; pitches emphasized by the orchestra; } \\
\text { the Three Chord Figure is introduced in } \\
\mathrm{m} 2 \text { and } \mathrm{m} 5 \text {. }\end{array}$ \\
\hline & & $0: 15$ & Mm11-16 & & $\begin{array}{l}\text { Final chord at the end of m10 is extended } \\
\text { and expanded upon by the orchestra. }\end{array}$ \\
\hline & & $0: 23$ & Mm17-24 & $\begin{array}{l}\text { Poco più leggiero; } \\
\text { Sempre energico; } \\
\text { RM } 12\end{array}$ & $\begin{array}{l}\text { Toccata figure in the organ again, } \\
\text { transposed with a pedal } E b \text {; counter } \\
\text { melody in the piccolo. }\end{array}$ \\
\hline & & $0: 29$ & $\mathrm{Mm} 21-24$ & Più pesante & $\begin{array}{l}\text { Three Chord figure in augmentation } \\
\text { accented by the strings. }\end{array}$ \\
\hline & & $0: 37$ & $\mathrm{Mm} 25-29$ & & $\begin{array}{l}\text { Toccata figures in the winds and brass or } \\
\text { perhaps it is an extension of the Three } \\
\text { Chord descending figure like earlier. }\end{array}$ \\
\hline & & $0: 44$ & Mm30-37 & $\begin{array}{l}\text { Più leggiero; RM } \\
13\end{array}$ & $\begin{array}{l}\text { Possible reintroduction to the jagged } \\
\text { rhythmic figures from "I. Earth's } \\
\text { Shadows." }\end{array}$ \\
\hline & & $0: 56$ & $\mathrm{Mm} 38-46$ & Dolce, espressivo & $\begin{array}{l}\text { Toccata Figure in the orchestra; organ and } \\
\text { strings are in the background, possible in } \\
\text { a related Chord } 1 .\end{array}$ \\
\hline & & $1: 12$ & $\mathrm{Mm} 47-56$ & $\begin{array}{l}\text { Più marcato, } \\
\text { fervente; RM } 14\end{array}$ & $\begin{array}{l}\text { Toccata figure becomes antiphonal } \\
\text { between various sections of the orchestra: } \\
\text { organ-brass-organ-strings-organ-winds; } \\
\text { Contrasting Motif in unison winds. }\end{array}$ \\
\hline
\end{tabular}




\begin{tabular}{|c|c|c|c|c|c|}
\hline & & $1: 29$ & Mm57-64 & $\begin{array}{l}\text { (M64: Molto } \\
\text { espressivo, } \\
\text { energico; RM 15) }\end{array}$ & $\begin{array}{l}\text { Toccata Figure in the brass followed by } \\
\text { Contrasting Motif in the winds. }\end{array}$ \\
\hline & & $1: 40$ & Mm65-73 & $\begin{array}{l}\text { (The Rehearsal } \\
\text { Mark seems to } \\
\text { fall on a pick up } \\
\text { to the new } \\
\text { section) }\end{array}$ & $\begin{array}{l}\text { Contrasting Motifs in the piccolo and } \\
\text { flutes; the organ has two long runs that } \\
\text { may be related to the ascending runs in } \\
\text { "Earth's Shadows." }\end{array}$ \\
\hline & & $1: 56$ & Mm74-83 & $\begin{array}{l}\text { Poco più intense, } \\
\text { ma Sempra } \\
\text { risoluto (M83 } \\
\text { Sempre fervente) }\end{array}$ & $\begin{array}{l}\text { Toccata figure in the winds; strings and } \\
\text { organ building part of Chord } 1 .\end{array}$ \\
\hline & & $2: 13$ & Mm84-92/93 & RM 16 & $\begin{array}{l}\text { Toccata Figure in the strings with } \\
\text { variances of the Constrasting Motifs in } \\
\text { the violins; this part overlaps into the next } \\
\text { phrase }\end{array}$ \\
\hline & & $2: 27$ & Mm93/94-104 & Con fuoco & $\begin{array}{l}\text { Antiphony of the Toccata Figure returns: } \\
\text { (possibly supposed to start in M93 in } \\
\text { winds) organ-winds/strings-organ- } \\
\text { horns/strings-and then they begin to } \\
\text { overlap and build to a climax. }\end{array}$ \\
\hline & & $2: 47$ & Mm105-108 & $\begin{array}{l}\text { Molto energico, } \\
\text { esaltato; RM } 17\end{array}$ & $\begin{array}{l}\text { Climax of the first section; nearly the full } \\
\text { orchestra on the Tutti Toccata Figure, } \\
\text { C/Db interchanged between the bass } \\
\text { notes. }\end{array}$ \\
\hline & & $2: 56$ & Mm109-120 & $\begin{array}{l}\text { Calendo poco a } \\
\text { poco ma sempre } \\
\text { ben ritmico }\end{array}$ & $\begin{array}{l}\text { Slow degradation of the climax; elements } \\
\text { of the Tutti Toccata are reduced until it is } \\
\text { strings and organ. }\end{array}$ \\
\hline \multirow[t]{6}{*}{ B (ruins) } & Dome & $3: 23$ & Mm121-130 & RM 18 & $\begin{array}{l}\text { The organ and violins play a remnant of } \\
\text { the toccata figure accented by percussion } \\
\text { and harp; Contrasting Motif in the } \\
\text { piccolo. }\end{array}$ \\
\hline & & $3: 47$ & Mm131-141 & RM 19 & $\begin{array}{l}\text { More remnants of the Toccata Figure in } \\
\text { the winds along with the Three Chord } \\
\text { Figure, first in augmentation, then in } \\
\text { diminution. }\end{array}$ \\
\hline & & $4: 13$ & $\begin{array}{l}\text { Mm142- } \\
149 / 150\end{array}$ & & $\begin{array}{l}\text { Continued references to the Toccata } \\
\text { Figure and the Contrasting Motifs; m } 150 \\
\text { is another transitional bar that may be a } \\
\text { pickup into the next phrase. }\end{array}$ \\
\hline & & $4: 34$ & $\mathrm{Mm} 150 /$ & $\begin{array}{l}\text { Con forza ma } \\
\text { espressivo; RM } \\
20\end{array}$ & $\begin{array}{l}\text { More references to elements found } \\
\text { previously; Toccata Figure is in antiphony } \\
\text { - in the winds first, then organ-low winds- } \\
\text { organ with brass building up. }\end{array}$ \\
\hline & & $4: 48$ & Mm159-160 & Feroce, con fuoco & $\begin{array}{l}\text { Another near full orchestral Tutti Toccata; } \\
\text { it is abruptly loud and only two measure } \\
\text { followed by a grand pause; E and F as the } \\
\text { lowest pitches. }\end{array}$ \\
\hline & & $4: 53$ & M161 & & $\begin{array}{l}\text { Grand pause (single measure rest with a } \\
\text { fermata). }\end{array}$ \\
\hline
\end{tabular}




\begin{tabular}{|l|l|l|l|l|l|}
\hline C (statues) & $\begin{array}{l}\text { Flowers, } \\
\text { ruins, } \\
\text { statues }\end{array}$ & $5: 00$ & Mm162-169 & $\begin{array}{l}\text { A tempo; Più } \\
\text { calmo espressivo; } \\
\text { RM 21 }\end{array}$ & $\begin{array}{l}\text { Nearly identical Contrasting Motif in the } \\
\text { organ in measures 162-163 as in measures } \\
\text { 25-26; a mixture of the Contrasting Motif } \\
\text { and the Toccata Figure until measure 168, } \\
\text { which is the Tutti Toccata in brass and } \\
\text { organ; ends with three triangle notes in a } \\
\text { single bar }\end{array}$ \\
\hline & Dome & $5: 15$ & Mm170-176 & Calmo, leggiero & $\begin{array}{l}\text { Another section nearly identical to } \\
\text { measures 31-35 in terms of texture and } \\
\text { general material. }\end{array}$ \\
\hline & $\begin{array}{l}\text { Earth's } \\
\text { Shadows }\end{array}$ & $5: 39$ & M182/183-187 & $\begin{array}{l}\text { Energico, poco } \\
\text { grave RM 22 }\end{array}$ & $\begin{array}{l}\text { First the Three Chord Figure in } \\
\text { augmentation followed by the Toccata } \\
\text { Figure, mostly organ solo. }\end{array}$ \\
\hline & $\begin{array}{l}181 / 182 \\
\text { 182, Contrasting Motifs descending in the } \\
\text { winds and violins; ends with four triangle } \\
\text { notes. }\end{array}$ \\
\hline Chord 1 & $5: 52$ & Mm187-188 & $\begin{array}{l}\text { Meno mosso, } \\
\text { espessivo; q=c. } 69\end{array}$ & $\begin{array}{l}\text { Final Tutti Toccata Figure, organ solo, } \\
\text { reminiscent of the first full orchestral } \\
\text { Toccata figure in Mm105-108; C/Db are } \\
\text { lowest pitches in the organ pedals. }\end{array}$ \\
\hline
\end{tabular}

Example 35 - overview of "Flowers, ruins, statues"

I found the final movement in Maan Varjot to be challenging both from a notated analysis but also a perceptible one as well. The climax of the work seems to coincide with the Tutti Toccata that happens in the middle of "Flowers, ruins, statues." The first time I listened to the work, it seemed strange to me that the piece would not end at such a high point when the forms of the first two movements seemed much more straightforward. But like any great piece of music, further investigations lead to greater understanding and appreciation and this last movement is no exception. 


\section{CHAPTER 4: Conclusion}

Maan Varjot is truly representative of Kaija Saariaho's style as a composer. There are mirrors and reflections and references to visual art, Earth and its vistas, and most importantly to this work, light and shadow. There are many dualities and dichotomies, oppositions and collaborations, and ideas that span the whole work that reflect other parts of the piece. In each of these moments, Saairaho is demonstrating how she uses a small amount of musical material, Chord 1, to create Maan Varjot.

Chord 1 is just the raw material though. The $51^{\text {st }}$ stanza of the poem Adonias provides a road map by which the entire work can be interpreted. Beyond that, there is interpretation of the poem itself that can derive a number of meanings in the music. The duality in the lines of the poem, which influence the individual movement titles, offer a lot for both the audience and performer to consider when interpreting Maan Varjot. This is not at the cost of Saariaho's voice as a composer either. The piece is an excellent example of the music she creates.

I hope that this paper will help to establish one way to analyze Kaija Saariaho's works as well as others who use similar pre-compositional (and sometimes spectral) techniques. There is enough material and evidence of the $[0,1, \mathrm{x}]$ building block across the whole work that it seems impossible to ignore. There are also chords throughout the work that are built in an orchestrally synthesized manner, including Chord 1. No matter how Chord 1 was created, it has clear importance to the structure of all the movements and Maan Varjot as a whole. The analysis this paper offers is one that could be repeated for 
other works that combine multiple compositional techniques or use similar material such as Chord 1.

Saariaho's use of the organ is interesting as well. Her collaboration with Olivier Latry offers a unique look into how the organ registration was created. The registration of the organ part is complex and challenging in a variety of ways including, and most importantly, in how the sounds it produces differ from the written notation. I am certain that Latry's proposed registration would be clear to most organist performers. Maan Varjot will likely have unique performances because of the registration challenge facing different organists in different acoustical spaces, but I do not believe that this is at the cost of Saariaho's compositional identity. In this way, she has achieved something remarkable.

What I hope I have accomplished in this paper is to show how multiple angles of analysis can help build a full picture to explain the inner workings of Saaraiho's music. In particular, the Comparative Model helped the aural analysis and connected several key sections of the piece. In Maan Varjot, the orchestrally synthesized Chord 1 showed a number of musical elements that informed the work as a whole. But having the Comparative Model offered another way to compare and contrast information that aurally sounded related. Combined with the use of set-class analysis and the formal implications behind interpreting the poem, this may prove helpful to others when looking at her future works as well as those she influences. Maan Varjot, as one of Kaija Saariaho's exemplary works, contains many of her interests and compositional techniques. The piece is unique in her oeuvre as it is the first work she in her catalogue that includes the organ as well as the fact that the organ is not often included in symphonic works. I hope that this paper 
will help guide others to look at her works in a manner that takes into account all of her interests. 


\section{Appendix 1: Creating a Comparative Model of the Chord 1 using Sine Waves and Digital Reverb}

In an attempt to reproduce a perceptible version of Chord 1 (Example 36) to be used as an aural reference in the analysis, I built a Comparative Model using waveforms from a synthesizer based on the orchestration, the registration of the organ, and the literal written notes in the organ part and orchestral score. The primary reason for this was to have an audio file to compare to the recording in the various moments where Chord 1 may have influenced other orchestrally synthesized moments, especially during the first and third movements. As noted in Chapter 2, the written pitches as notated on the score are different than what is produced and perceived because of the stops proposed by the composer and Olivier Latry for the organ as well as the doublings found in the orchestra. Two primary aspects needed to be approximated in order to achieve the best possible version: the acoustical space in which those pitches are heard and an approximation of the pitches found in Chord 1 using sine waves that I will call the Comparative Model.

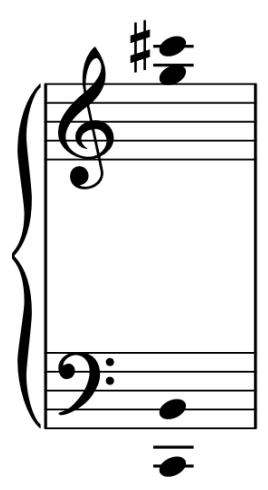

\section{Example 36 - Chord 1}


Beginning with the acoustical space, the two best representations of the reverberations found in the Maison Symphonique du Montréal Hall premiere recording are found in the third movement. There are two moments in "Flowers, ruins, statues" where most of the symphony abruptly stops and, in the second example, the organ abruptly stops. Both of these moments offer a chance to analyze and recreate the acoustic of the hall for the Comparative Model. In the YouTube video demonstration of the organ from Montreal Symphony's YouTube page, the organist claims that the acoustic is approximately two to three seconds. ${ }^{83}$ The spectrograms of the recording back this claim as seen below.

The first place to gauge the acoustics occurs is at approximately $4: 53$ in the recording of the third movement. While some instruments continue resonating in the recording, such as the vibraphone, the majority of the instruments have ceased playing. The reverberation of the symphony's sound continues in the acoustic of the concert hall for approximately 2 to 2.5 seconds. In the spectrogram of the recording, this can be seen and is shown in Example 37 where the decay ends somewhere approximately in the circle. $^{84}$

\footnotetext{
83 Orchestre Symphonique de Montréal, "The Organ at Maison Symphonique de Montréal," Accessed June 282020 https://www.osm.ca/en/the-organ.

${ }^{84}$ The spectrograms were realized using the Digital Audio Workstation (DAW), Reaper and its Spectral Edits plugin.
} 


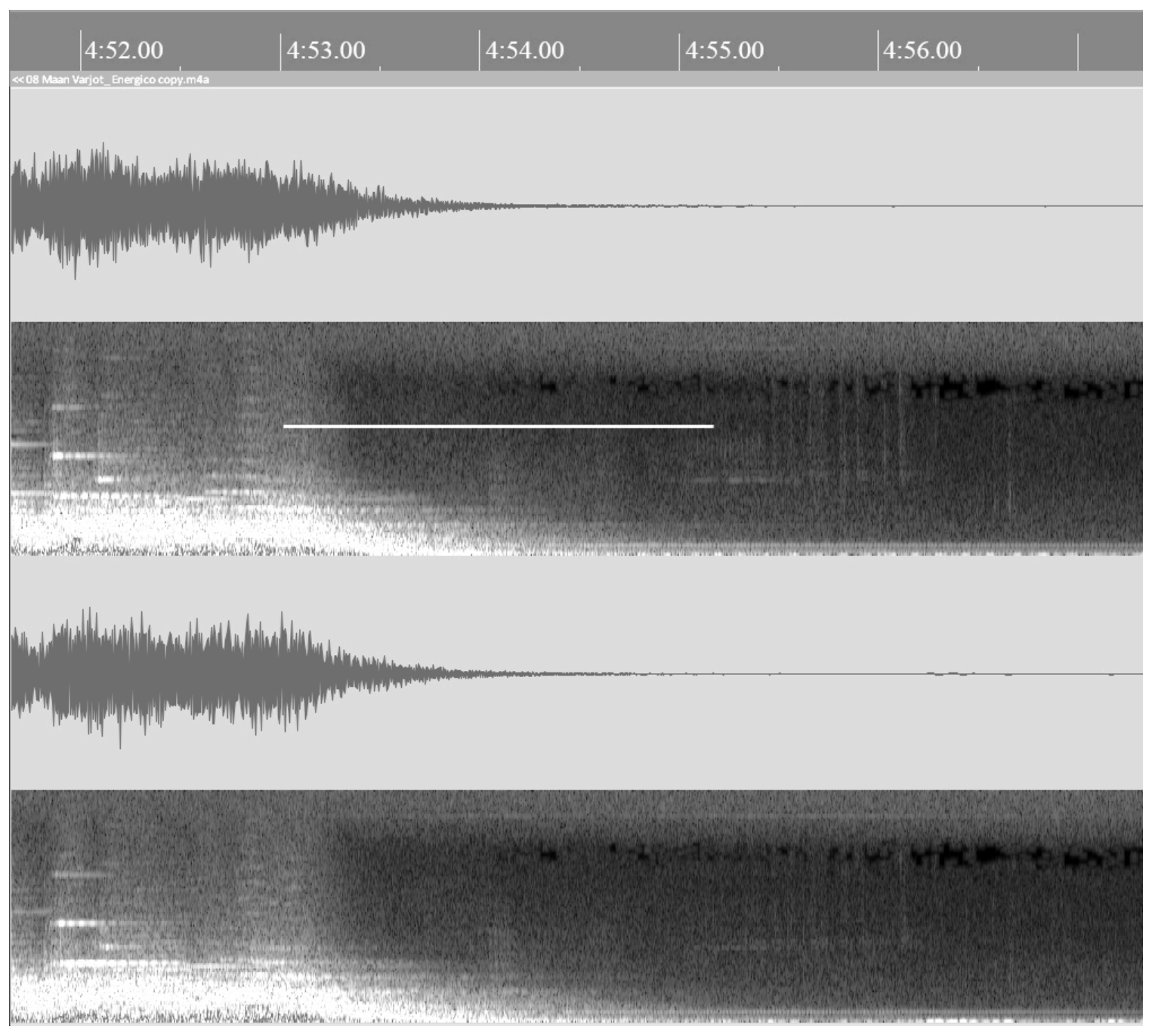

Example 37 - First example of the reverberation in the Maison Symphonique de Montréal in the third movement of Maan Varjot after the nearly tutti orchestra.

The second time happens after the organ ends in a similarly abrupt manner at approximately 5:57. As with the example above, the spectrogram demonstrates the acoustic of the space to be between 2 and 2.5 seconds in Example 38. A bass drum strike occurs at this point in the recording and can be seen at 5:59 during the decay of the organ. It muddies this example of the acoustical space but not enough to question the amount of time as demonstrated also seen in Example 36. The circle in Example 37 represents the 
approximate ending of the organ sounds reverberation in the hall. Recreating the acoustical reverberation in this space is important as it helps reproduce the partials that would be found in Chord 1.

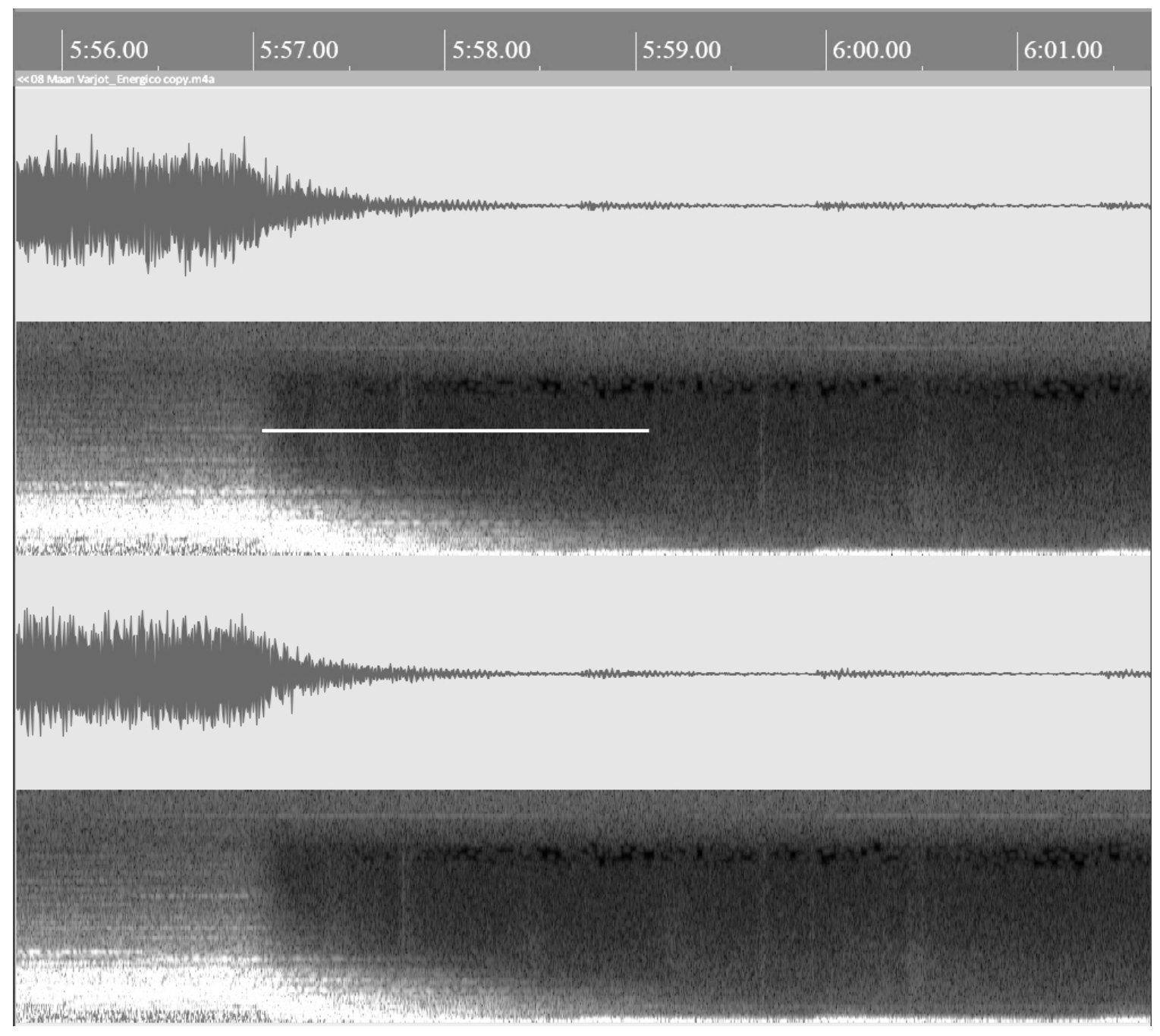

Example 38 - Second example of the reverberation in the Maison Symphonique de Montréal in the third movement of Maan Varjot after the full organ. 
I approximated the acoustical space of the hall using Reaper's digital reverb plugin, ReaVerbate, using the settings shown in Example $39 .{ }^{85}$ The dampening component was reduced to 0 as sine waves do not produce harmonics by themselves. Dampening controls how much the higher frequencies are absorbed in a given space. The higher the dampening is set, the more the highest frequencies are absorbed into the digital acoustical space. $^{86}$

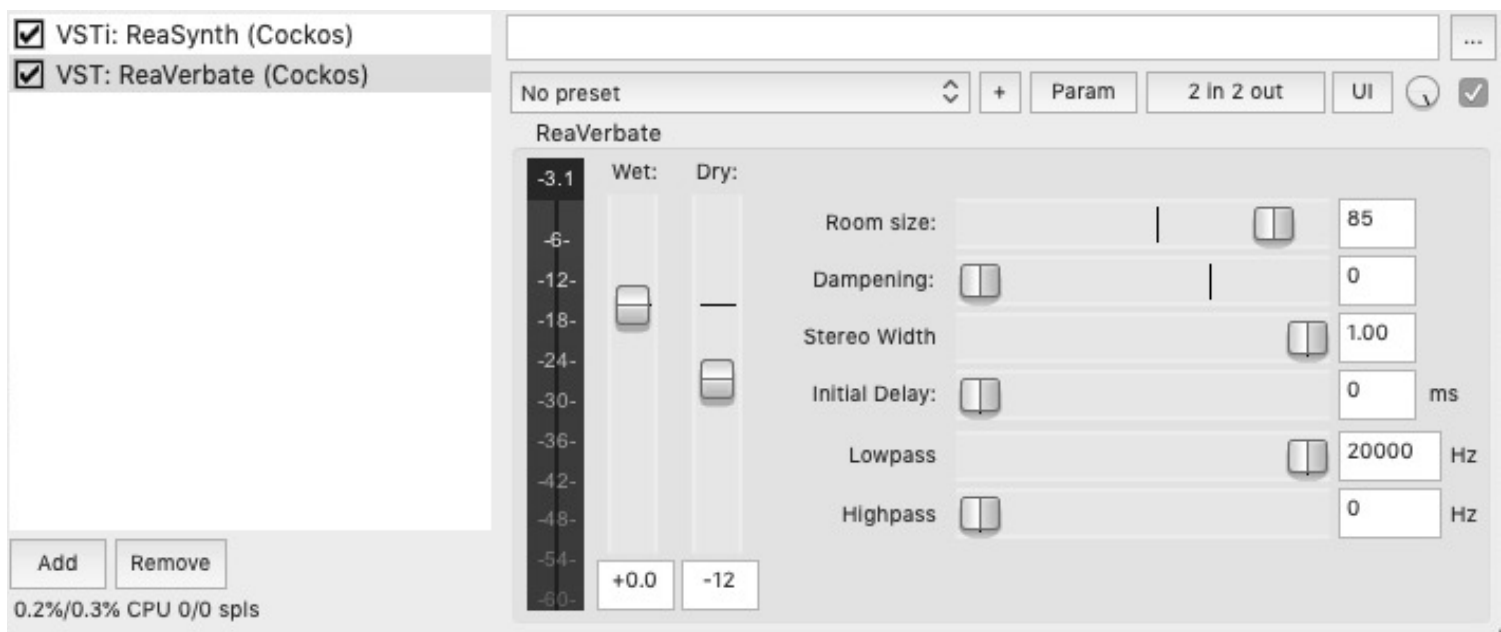

Example 39 - ReaVerbate settings to digitally approximate the acoustics of the concert hall

With the creation of the digital acoustical space, the next step needed in the analysis would be a spectral realization of Chord 1 . Because Chord 1 contains more information than what is written, spectral analyses of the three moments where it appears

\footnotetext{
${ }^{85}$ Reaper is a Digital Audio Workstation created by the company Cockos. Both the spectral analysis of the recording of Maan Varjot and sine wave model that was built were done through this program. For more information about the program, visit the site http://www.reaper.fm.

${ }^{86}$ Jon Tidey, "ReaVerbate Tutorial and Free presets," Reaper Blog, March 10, 2016, https://reaperblog.net/2016/03/reaverbate-tutorial-and-free-presets
} 
are essential to replicating it. The following examples come from the beginning of the first movement (Example 40), the end of the first movement (Example 41), and the end of the third and final movement (Example 42). Because the Comparative Model was also used for comparison, the Toccata Figure (Example 43) and the Tutti Toccata Figure (Example 44) are also included. All of these examples were normalized, a process that maximizes the amplitude without the audio samples clipping. ${ }^{87}$ This process helped in keeping a consistent decibel level between each recording sample and the Comparative Model.

${ }^{87}$ Glenn D. White, and Gary J. Louie, The Audio Dictionary: Third Edition, Revised and Expanded, Seattle; London: University of Washington Press, 2005: 261. The additional decibels can be seen in the upper right hand of each example. 


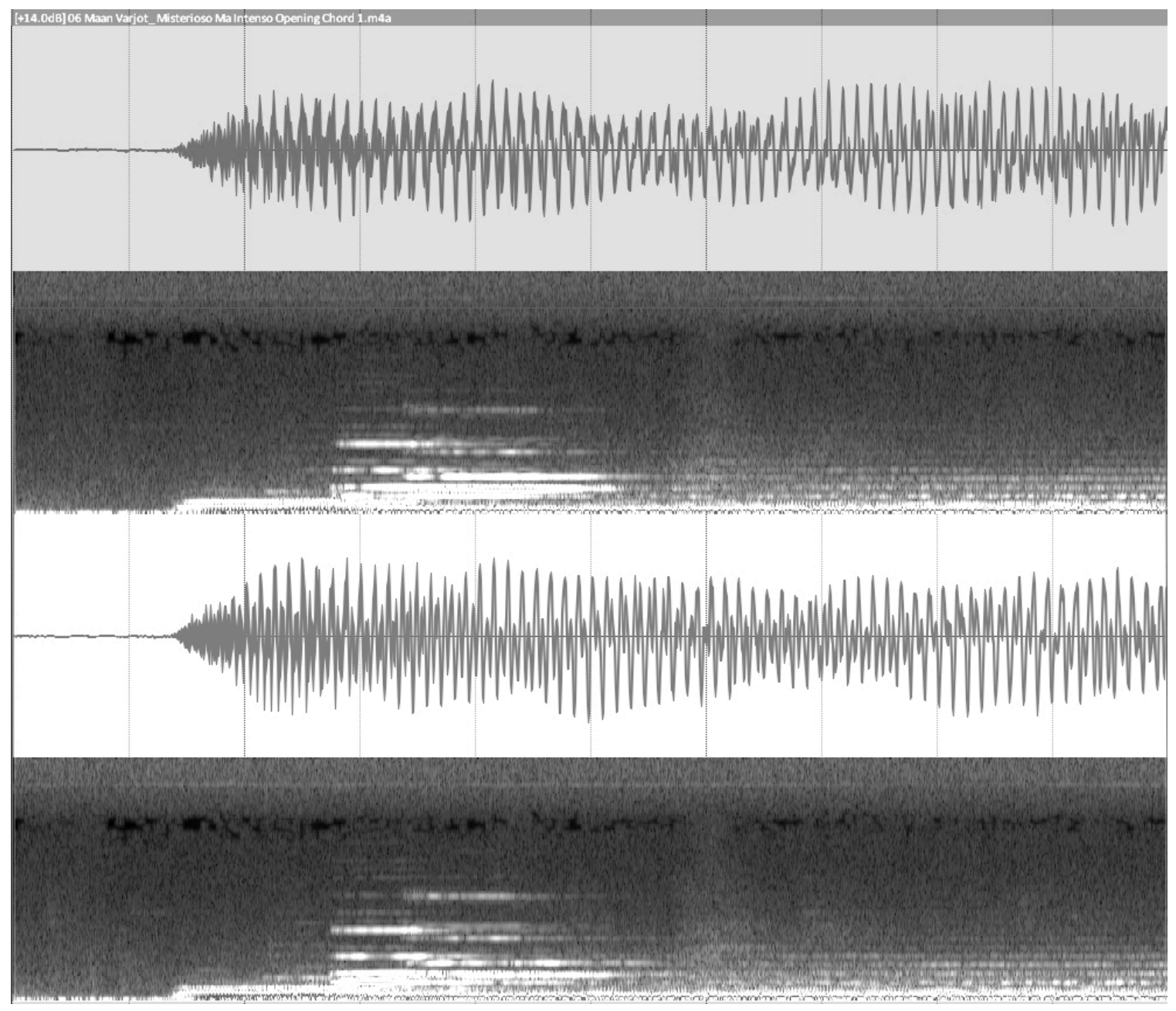

Example 40 - "I. Earth's Shadows," 0:00 - 0:05 (into the recording) 


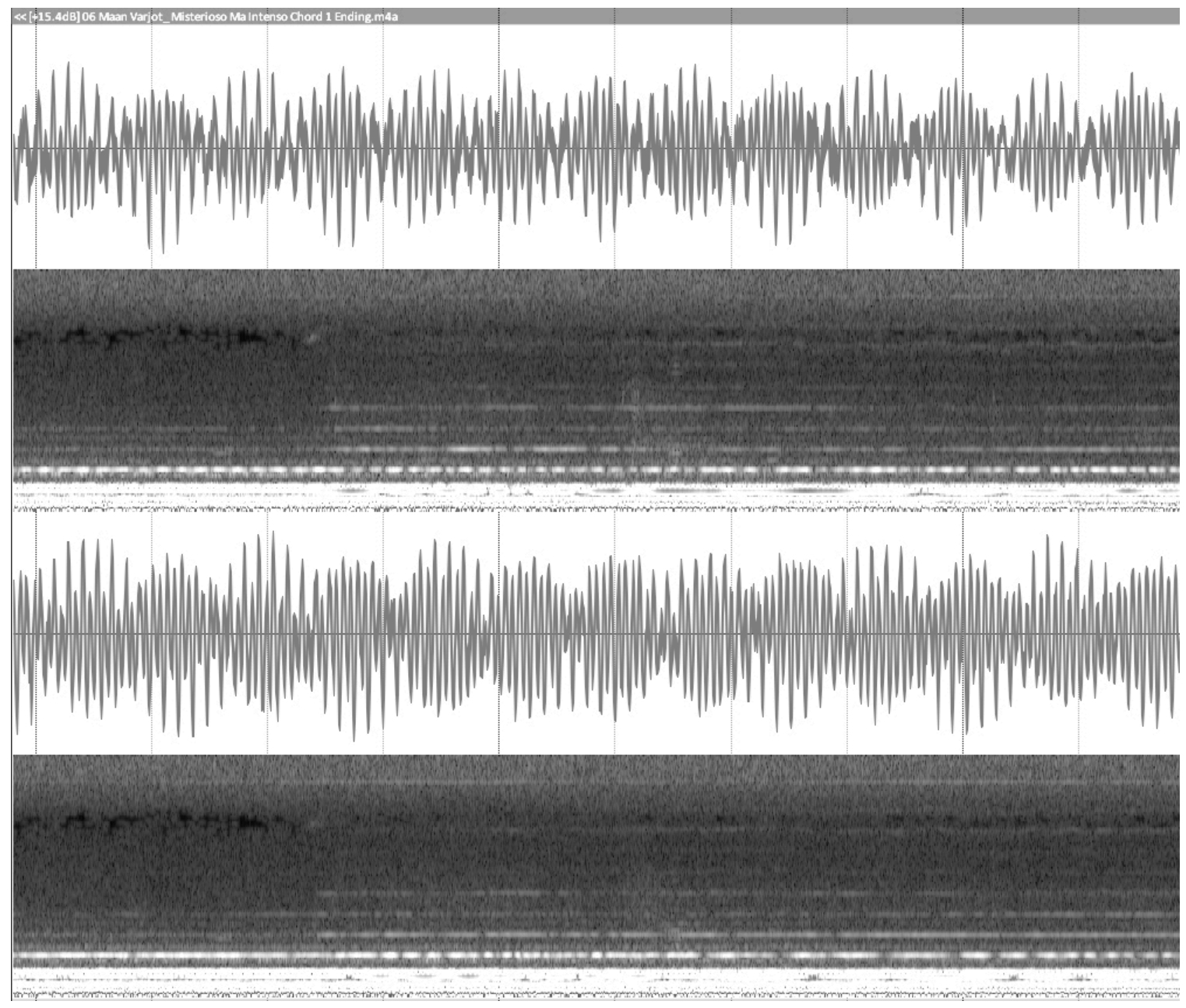

Example 41 - “I. Earth's Shadows," 4:58-5:02, piccolo entrance 


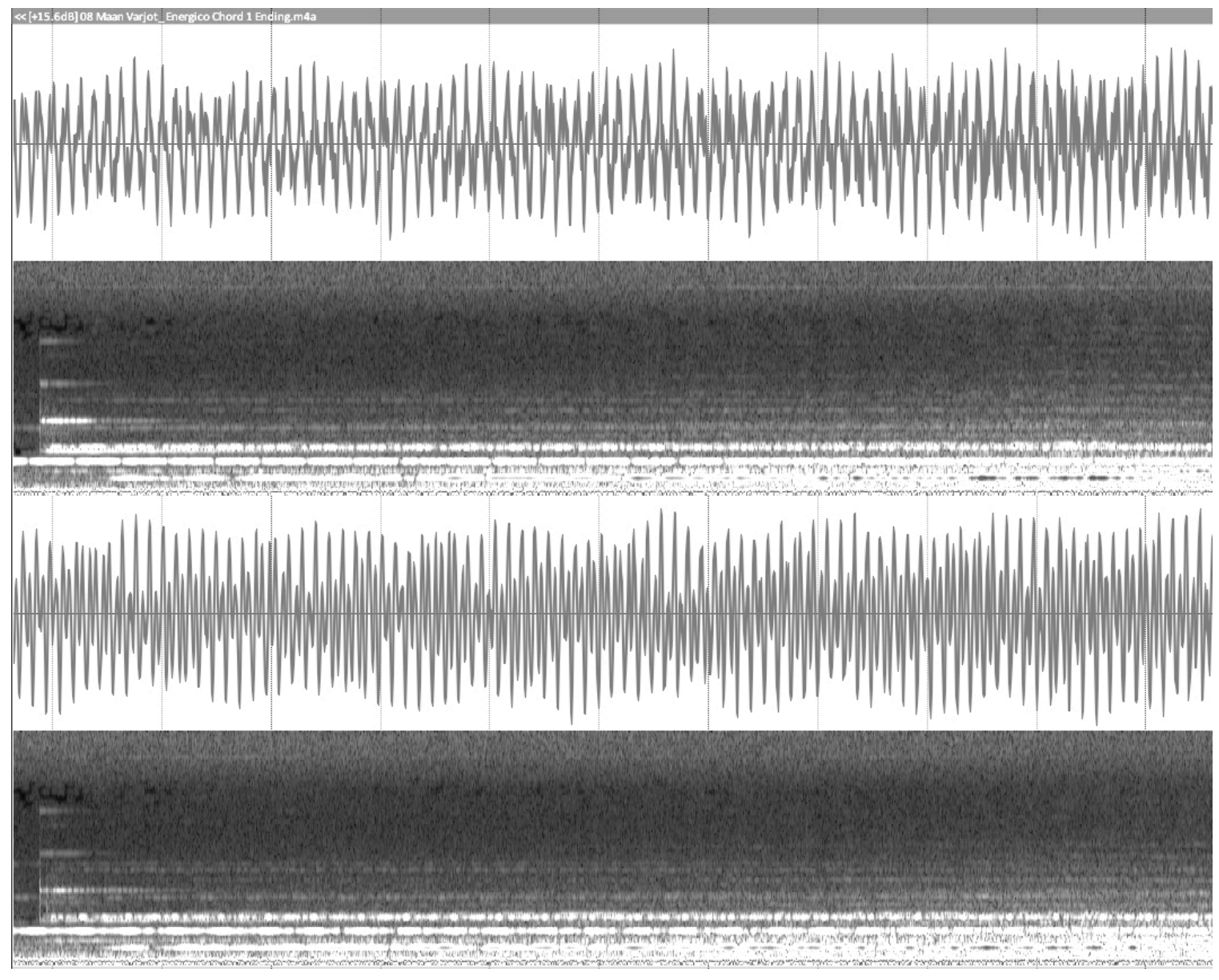

Example 42 - "III. Flowers, ruins, statues," 6:09-6:13 


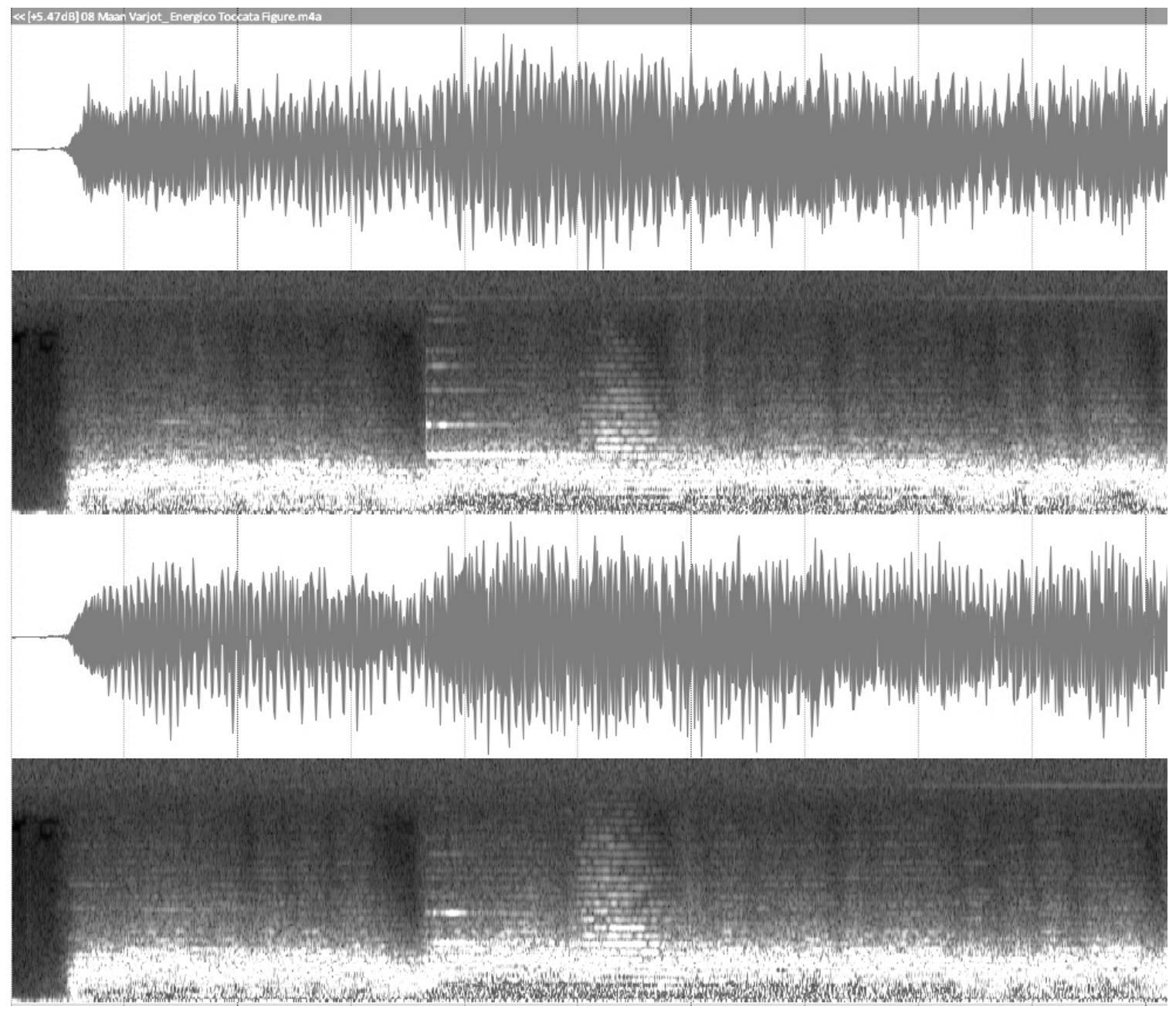

Example 43 - "III. Flowers, ruins, statues," 0:00-0:05, Toccata Figure 


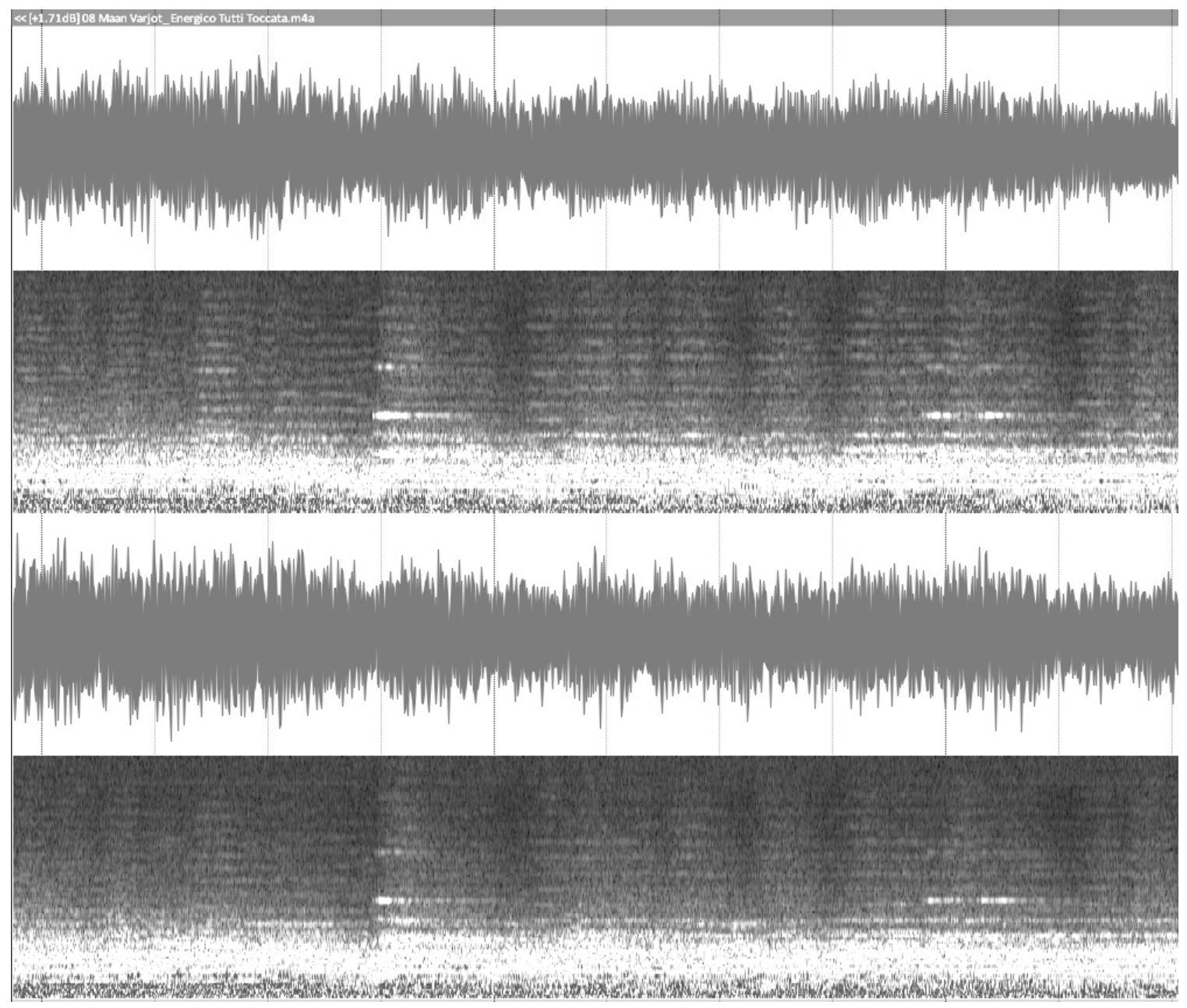

Example 44 - "III. Flowers, ruins, statues," 2:49-2:54, Tutti Toccata Figure

Once this was accomplished, three versions of Chord 1 were created: one using the literal written pitches on the score, a second realizing the recommended registration and pitches, and a final one utilizing a combination of the first two. Sine waves, or sinusoids, were chosen to begin the model due to the waveform's general purity and lack of harmonics. ${ }^{88}$ Additionally, a sawtooth waveform, was mixed in slightly to the model to

${ }^{88}$ Lieder, Colby, Digital Audio Workstation, New York: McGraw Hill, 2004: 10. There are many resources available describing these waveforms in the creation of sound. Outside of the field of physics and mathematics, the best available descriptions of these waveform sounds can be found in books on DAWs. Another definition can be found on 
add some upper partials as live acoustic instruments would as well. The first model using the literal written pitches with the approximated digital acoustic does not contain many harmonics (see Example 45). Compared to the spectrograms above, it is clear that the literal written pitches do not fully represent the first three versions of Chord 1 . There are similar elements and partials, but it warranted the creation of another model.

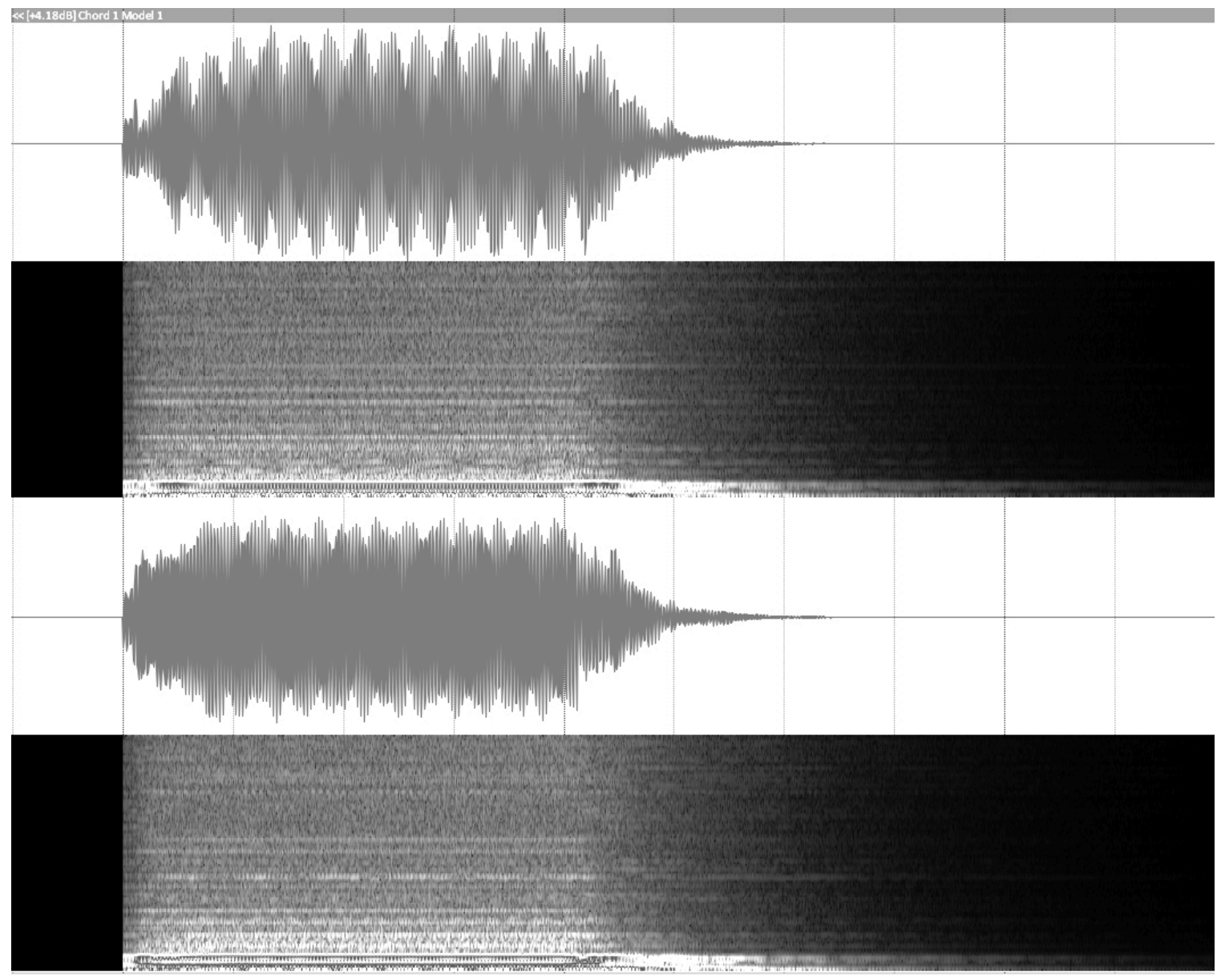

\section{Example 45 - Literal written pitch realization}

Wikipedia at https://en.wikipedia.org/wiki/Waveform. The sine waves were produced using Cockos plugin within Reaper, ReaSynth. ReaSynth is a simple plugin capable of creating simple waveform sounds, including sine, square, triangle, or sawtooth waveforms. A description of the Cockos ReaSynth plugin can be found on the unofficial Reaper blog at https://reaperblog.net/2015/01/video-reasynth-and-reasyndr-plugin-demo10-free-presets/. 
The second model that I built realized all of the pitches from the recommended registration for the organ in the opening of the first movement. In order to accomplish this, I needed control over the amplitude of the highest pitches and did so using the Reaper plugin, ReaPitch. The registration for the manuals includes a 4', 2 2/3', 1 3/5', and $1^{\prime}$. Using the 4' as the primary pitch, ReaPitch performs the upper pitches while giving control over how present they are in the mix. The Pedals were done on a separate track at $32^{\prime}, 16^{\prime}$, and $8^{\prime}{ }^{89}$ The two tracks were bounced together and a spectrogram was realized. The results can be seen in Example 46.

${ }^{89}$ A score notation of the recommended registration can be found in Chapter 2, Example 4. 


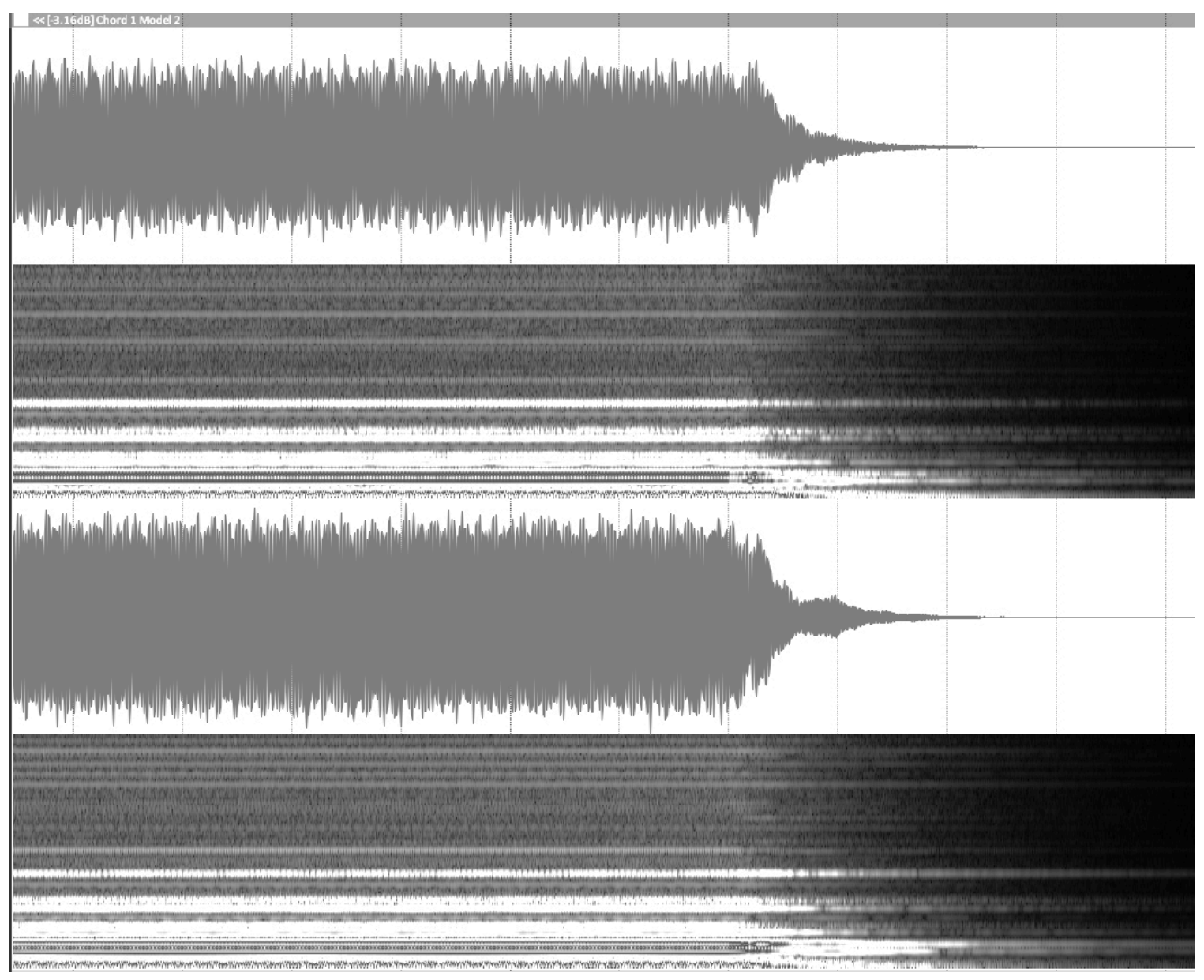

Example 46 - Realization with the all of the pitches in the recommended registration

This second model is much closer to Chord 1 than the first, especially when compared to Chord 1 found at the beginning of "Earth's Shadows." The emphasized partials help give this model a stronger aural profile. But when it is placed against the other versions and moments of Chord 1, its general timbral profile does not align well.

The last realization attempted to combine the written pitches, from the organ and orchestra, with the recommended registration. The most important pitch for the pedals in the recommended registration would be the $16^{\prime}$ and $8^{\prime}$. The $32^{\prime}$ in not included as it would be difficult to perceive due to its low frequency. The registration for the manuals 
includes the mutation stops that emphasize partials, they were left out because of the sawtooth waveform likely including those pitches in the harmonics. The 4' flute would be the strongest literal pitch from the organ. Alongside the 4' sounding an octave higher than written, the orchestra doubles those same notes but at concert pitch. That would necessitate the inclusion of Chord 1's notes at concert pitch. Notation for this version of Chord 1 is found in Chapter 2, Example 5. Example 47 is the spectrogram realization of this model.

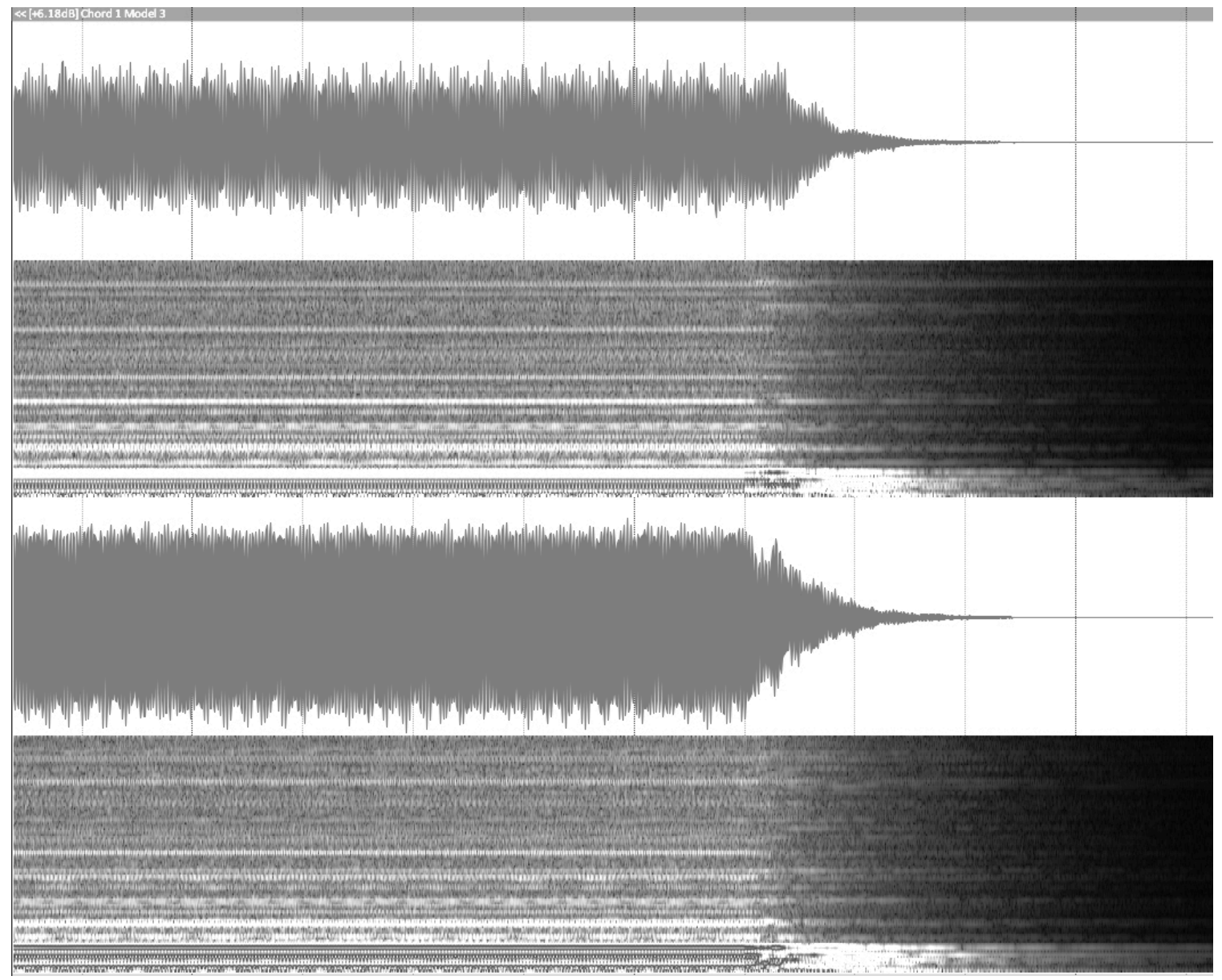

Example 47 - Third model built based on a combination of the notated pitches and the recommended registration 
This third and final model proved to be the closest approximation of all versions of Chord 1 and helped as a Comparative Model when placed against the recording. When the recording spectrograms and the Comparative Model are placed next to one another, there are commonalities between each version of Chord 1 from the recording and the third model (Example 48). The lowest and loudest pitches are where the model seems to most resemble the recording, but that is expected since they all share a pedal $\mathrm{C}$ at the same pitch. One challenge in creating these charts is that the music is not static but exhibits a constant change of timbre. In example 48c, one partial lined up on the left side of the Comparative Model while others appear later. This was certainly the case for these three examples of Chord 1 in the recording. 


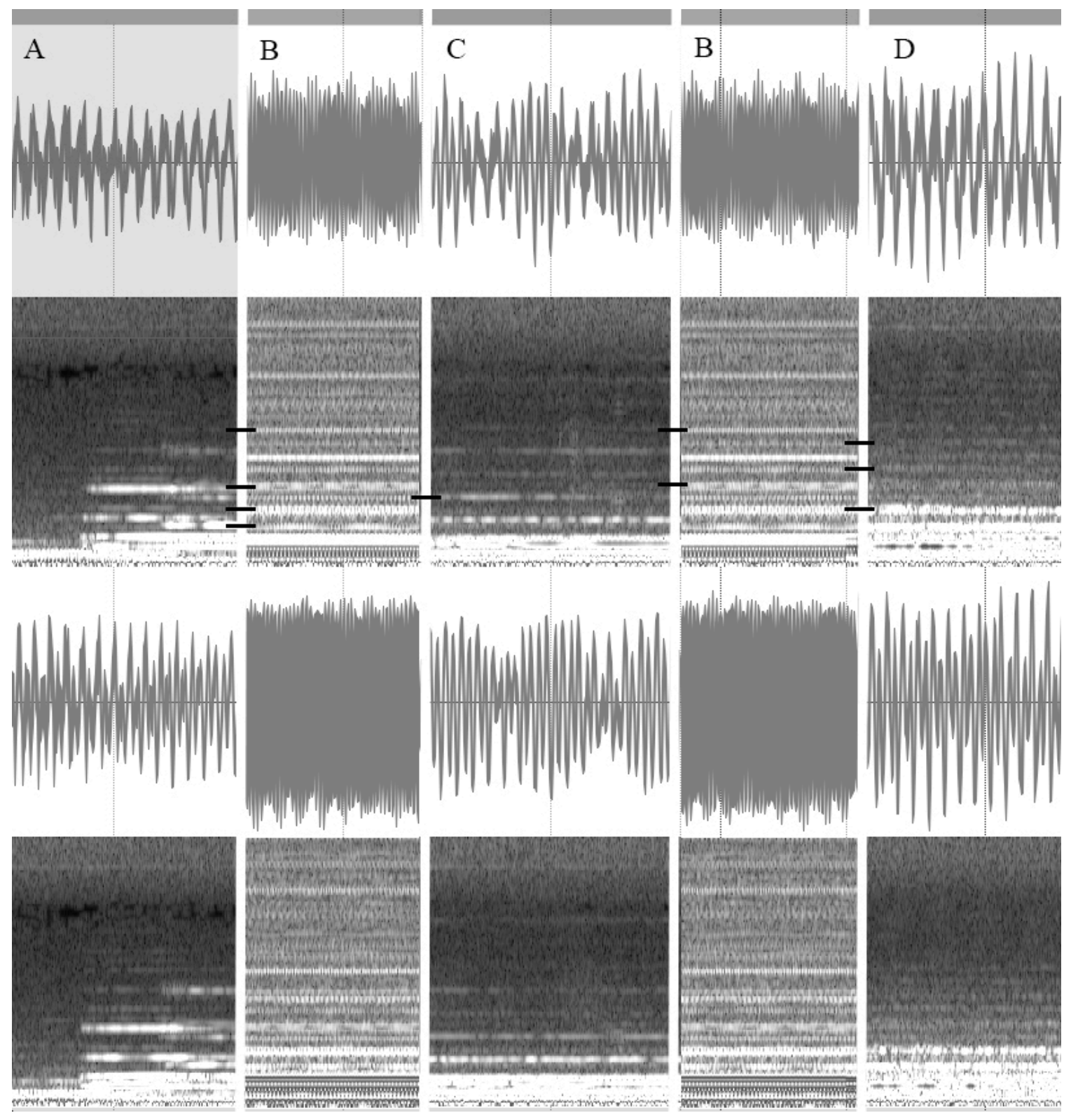

Example 48 - Comparisons of the spectrograms: A - Chord 1 from "Earth's Shadows opening," Example 40; B - Comparative Model from Example 47; C Chord 1 from "Earth's Shadows" ending, Example 41; D - Chord 1 from "Flowers, ruins, statues," Example 42

The next step in the process was comparing the spectrographs between the Comparative Model and the moments where Chord 1 seems to have influenced Maan 
Varjot. In the first movement, Chord 1 gradually develops into the Elaboration Chord. There are elements that are similar between their pitch material as discussed in Chapter 3, Part 1. Looking at the spectrogram of the first time the Elaboration Chord appears (Example 49) and then placing them side by side with the Comparative Model show some of the partials they share in common (Example 50).

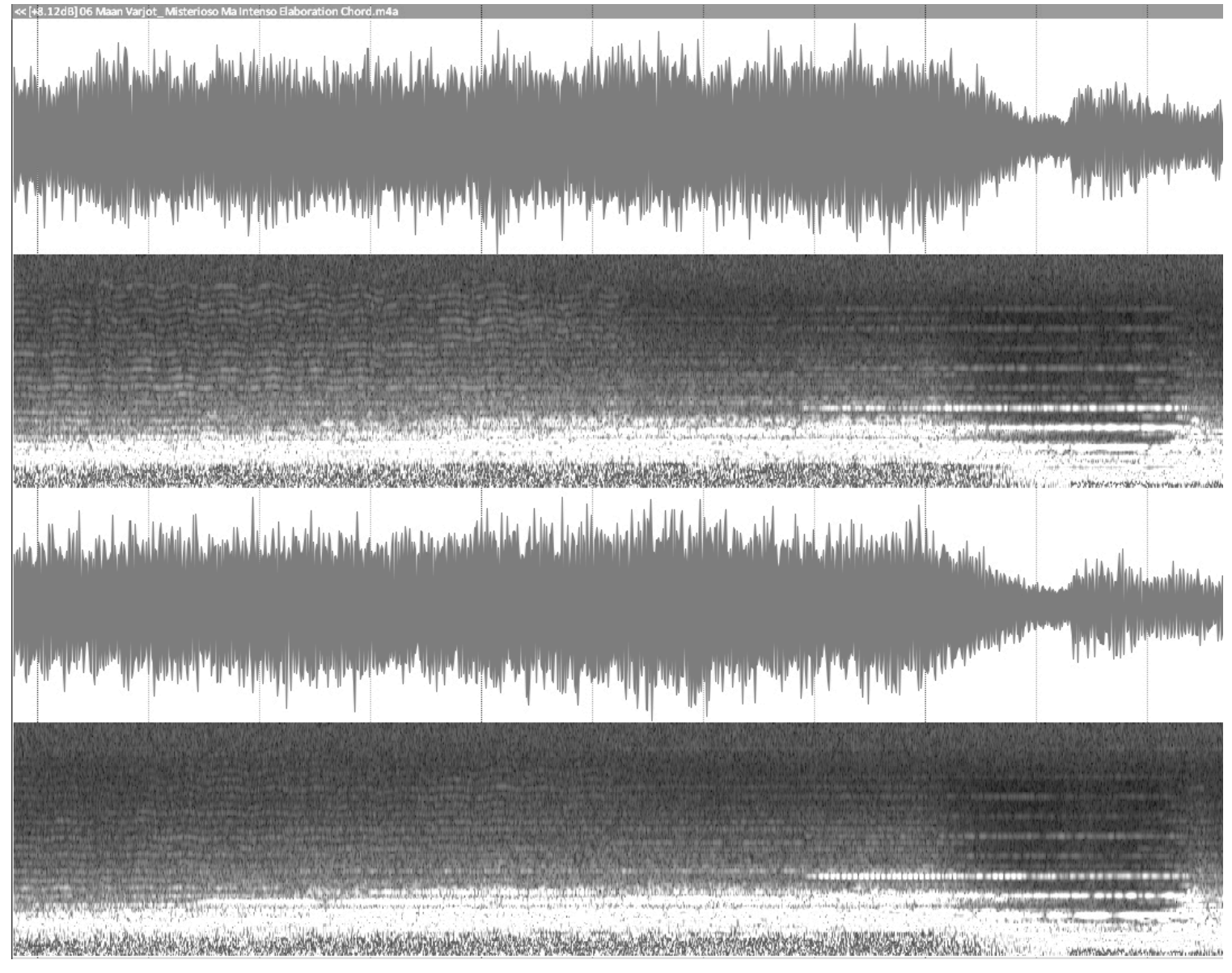

Example 49 - Spectrogram of the Elaboration Chord, 1:25-1:29 


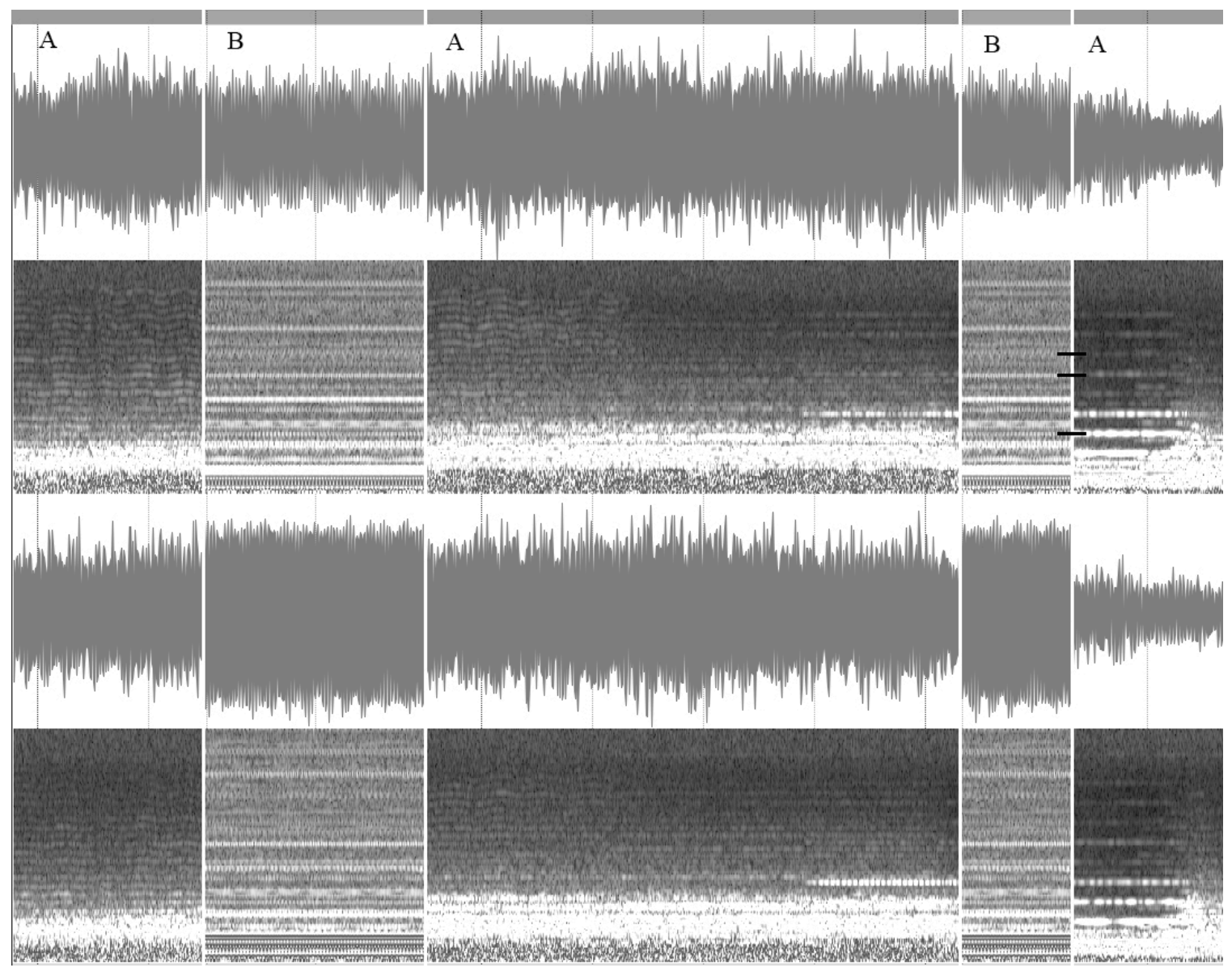

Example 50 - Comparisons of the Elaboration Chord, A, and the Comparative

Model, B

The spectrogram of this moment in the Elaboration Chord shows constant change in the harmonic spectra in the recording. The advantage of the Comparative Model in contrast to Chord 1 is that it remains consistent in its sound production through those moments in the recording. In this moment, the Elaboration Chord moves from being unrelated to Chord 1 until the end of its development and what overlaps into the beginning of the first B section in "Earth's Shadows."

Two other examples from above, the Toccata Figure and the Tutti Toccata Figure are given comparisons in Example 51 and Example 52. Both comparisons show 
similarities as seen before where partials are present in both of the Toccata Figures and the Comparative Model. The Toccata Figure in Example 51A show continuously moving and flowing timbres and, when compared to the steadiness of the Comparative Model in Example 51B, the partials flow in and out as the recording moves forward. Similarly, the Tutti Toccata Figure, Example 52A, moves and flows in and out of the partials of the Comparative Model, Example 52B.

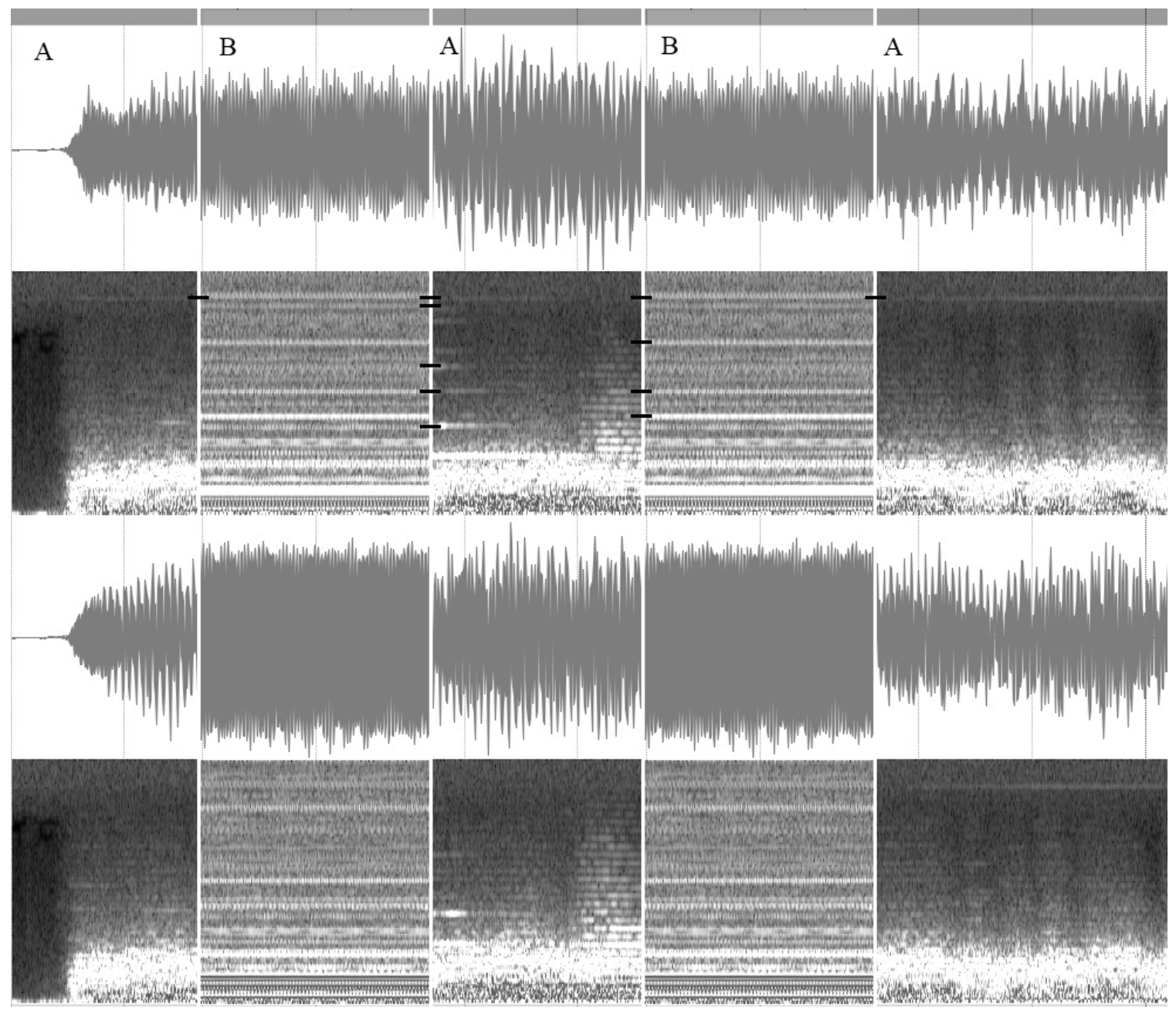

Example 51 - The Toccata Figure primarily in the organ at the beginning of "Flowers, ruins, statues," 0:00-0:05 


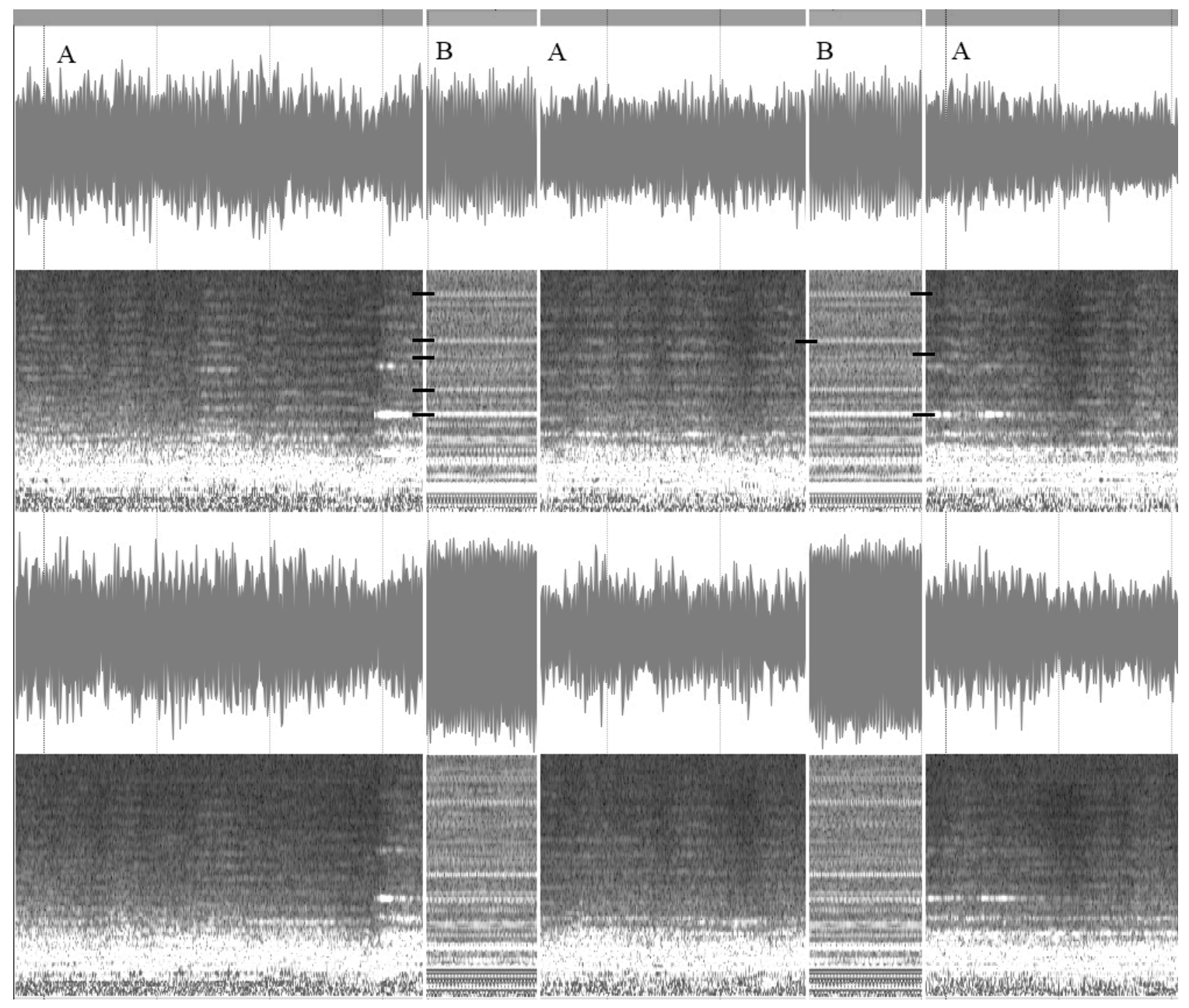

\section{Example 52 - The Tutti Toccata Figure in the middle of "Flowers, ruins, statues"} with most of the orchestra, $2: 49-2: 53$

Lastly, placing the Comparative Model next to Chord 2 does not demonstrate any commonalities, at least not in this perceivable aural model (Example 53). The harmonic spectrum of Chord 2 is quite different than that of the Comparative Model and by proxy, Chord 1. If there is an aural connection between the two chords, I am unaware of how and have not been able to decipher it. If there is one connection, it is that Chord 1 and 
Chord 2 are orchestrally synthesized and their related intervallic pitch material as demonstrated in Chapter 3, Part 2.

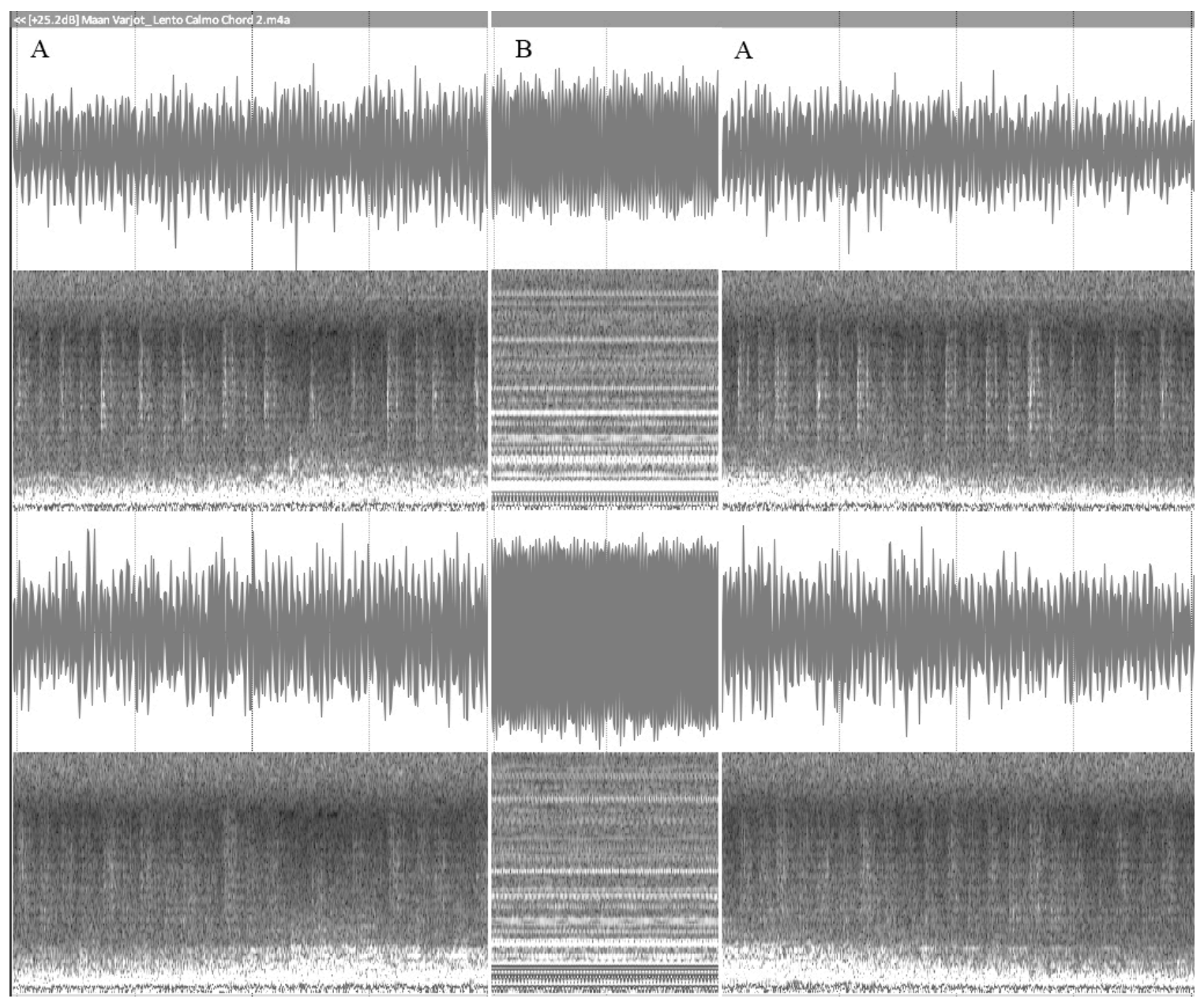

\section{Example 53 - Chord 2 at the beginning of "Dome," A, and the Comparative Model,} B, 0:20 - 0:25

The Comparative Model proved to be highly useful as it allowed me to draw connections to the music beyond the score. Maan Varjot presents Chord 1 in a fluid and moving manner and the steady Comparative Model allowed me to draw more direct aural connections. 


\section{Appendix 2: General Issues Surrounding Pipe Organ Registration}

To reiterate what was said in Chapter 2 regarding organ registration, or registering an organ work, it is a challenge that faces organists when interpreting most pieces on most instruments. Again, registration at the organ refers to the selection of stops, which are the groups of pipes with a specific tone color, to match the repertoire being performed. ${ }^{90}$ This also includes pitch, as some stops do not sound as written and are often an octave higher or more than the note that is written. ${ }^{91}$ This challenge can even be seen in various traditions across countries and time periods based on how organs and pipes were constructed. It is for these reasons that the registration for Maan Varjot is a proposal and not specific demand. This guides an organist in adapting the organ part to the instrument at hand as the registration presents challenges that are at the forefront of interpretation. Namely, that the proposed registration may not be completely achievable on an instrument. In an interview for the premiere of Maan Varjot in England, Saariaho commented on and welcomed the challenge of creating a work with organ because, while every organ sounds different, she wanted to maintain her identity as a composer. ${ }^{92}$

The literature and history of organ registration often divides their developments into time period and region. To give another example of this outside of Chapter 2, the construction of organs in $17^{\text {th }}$ century England was different than Italian instruments of

\footnotetext{
${ }^{90}$ Fenner Douglass, Barbara Owen, and David Fuller, "Registration," Grove Music Online, 2001; Accessed 20 June 2020, https://www-oxfordmusiconlinecom.www.libproxy.wvu.edu/grovemusic/view/10.1093/gmo/9781561592630.001.0001/o mo-9781561592630-e-0000047609.

${ }^{91}$ Ibid.

92 "Esa-Pekka Salonen, Kaija Saariaho and Olivier Latry introduce Saariaho's Maan varjot," Youtube video, 08:06, June 12, 2014, http:/www.youtube.com/watch?v=p4lfQyImhY
} 
the same time. The repertoire is also reflective of this difference. For the modern performer, an instrument that matches the repertoire being performed is ideal but is often not attainable. For example, an organ student in mid- $20^{\text {th }}$ France at the Paris Conservatory would be required to perform Johann Sebastian Bach, of $18^{\text {th }}$ century Germany, on instruments in modern France. ${ }^{93}$ These two things are not necessarily compatible in attempting to recreate an authentic registration simply because the instruments would not have the same basis of construction. This requires an organist to have an understanding of how organs developed through history and how the organs from various regions may have been performed upon, including how the stops from their respective repertoire were used enabling the organist to adapt the work for the instrument at hand.

The numbers next to each of the stops refer to the octave in which the pipe sounds. 8 foot (8') stops sound at concert pitch, 4' stops sound an octave higher, 2' stops sound two octaves higher and a 16' stop sounds an octave lower. The stops that include fractions and roman numerals, called mutations and mixtures, sound at a different pitch and octave than written. The Nazard 2 2/3', a mutation stop, sounds one octave and a fifth higher, emphasizing the third harmonic of a fundamental. The Roman numeral stops, mixtures, sound multiple pipes at the same time. The number found in the Roman numeral tells the number of pipes that sound for a single note. Mixtures, in general, emphasize several high partials of the note being played. ${ }^{94}$

${ }^{93}$ Michael Murray, "Marcel Dupré: The Work of a Master Organist," Boston: Northeastern University Press, 1985: 119.

${ }^{94}$ Thistlethwaite, Nicolas, and Geoffrey Webber, ed., The Cambridge Companion to the Organ, Cambridge: Cambridge University Press, 2006: 27. This volume has an excellent overview of pipework and organ construction. The Grove Dictionary of Music has the 
There are a couple of specific ranks that need explanation as it may help in understanding how registering Maan Varjot may be a challenge. The first is the celeste stop. It was given a brief explanation Chapter 3, Part 2, and deserves a clearer definition. Harold Gleason defines the voix céleste as "a string stop tuned higher than normal pitch, designed to be used with a string of normal pitch to produce a vibrating effect." ${ }^{\text {95 }}$ Celestes are most commonly associated with string stops, pipes that have a thinner and more nasal sound in the manner of a stringed instrument. ${ }^{96}$ Flute celestes achieve the same effect but with flute pipes rather than string pipes. Celestes are used in all three movements of Maan Varjot.

Another grouping of stops needing explanation are the reed pipes. The way these pipes are constructed include a reed that vibrates inside an enclosure called a boot. ${ }^{97}$ What is important for this paper in understanding these ranks are that many reed pipes are named after instruments in the orchestra. There is much variety in reed pipe stops but there are ways of accommodating what the score proposes. An example of this in Maan Varjot is given below.

Finally, the most difficult part in interpreting the organ score is related to the generic registration markings. There are many moments when Latry proposes a specific stop or group of stops but there are also times when he does not. In these moments, terms

article "Organ," by Barbara Owen, Peter Williams and Stephen Bicknell, which can provide a more thorough account of organ building and pipework.

${ }^{95}$ Harold Gleason, Method of Organ Playing, Eighth Edition, Upper Saddle River, New Jersey: Prentice Hall, 1996: 367.

${ }^{96}$ Barbara Owen, Peter Williams, and Stephen Bicknell, "Organ," Grove Music Online. 2001; Accessed 30 June 2020, https://www-oxfordmusiconlinecom.www.libproxy.wvu.edu/grovemusic/view/10.1093/gmo/9781561592630.001.0001/o mo-9781561592630-e-0000044010.

${ }^{97}$ Ibid. 
like flutes or reeds are used to indicate what group of timbres is recommended. Another generic registration term that appears regularly is Foundations. The term Foundation is used when all or most of the principle, flute, and string stops are called for, without the celestes, reeds, or mutations and mixtures. ${ }^{98}$ The key to Foundations are the number or numbers that follow indicating the octaves needed. Alongside a dynamic marking, an organist would be able to determine how many stops to include.

Listed below in Examples 51 and 52 are the stop lists for two known venues where Maan Varjot was performed. They show the registration possibilities for each organ and the respective keyboards, or manuals, and pedals. Registration lists are often divided first by the Foundation, mutation, and mixture stops in order of lowest to highest octave, followed by the reeds in the same manner. Expressive manuals, or in the cases below expressif or enclosed, are ranks that are in a case that has the ability to open and close shades to give the impression of dynamics. There are foot pedal switches that allow the organist to control the shades.

In the specific case of Maan Varjot, the registration requirements are constantly evolving and there are instances where adaptations have to be made. One example of this can be found in the second movement, "Dome," where the highest voice in the right hand has a registration of "French Horn." 99 The organ at the Maison Symphonique du Montréal Hall (Example 51) has a French Horn (Cor français) on the expressive Grand Choeur manual (keyboard). This is in contrast to the organ at the Walt Disney Concert Hall (Example 52) which does not have this specific stop. The organ does have an

\footnotetext{
${ }^{98}$ Roger E. Davis, The Organists' Manualm New York: W. W. Norton \& Company, 1985: 203.

${ }^{99}$ Example 14 in Chapter 3, Part 2, is the moment in the score where this registration happens in the uppermost voice.
} 
English Horn (Cor Anglais) on the Positive manual and could be a potential substitute for what is in the actual score. Whether the Cor Anglais is an appropriate substitute, the organist would need to choose a reed of some type for this moment in the piece.

In Chapter 3, Part 2, the analysis of Chord 2 presents an idea that it is a challenge to perceive the pitches based on the orchestration and registration. The proposed registration during Chord 2 at the beginning of "Dome," calls for flute celestes and yet none are on the organ at the Maison Symphonique du Montréal Hall used for the premiere recording. It is possible that Latry used a tremulant, or tremolo stop, which varies the wind going through a pipe and alters the pitch and dynamic of the pipes creating an undulation. ${ }^{100}$ While this is a supposition based on my interpretation of the recording, this effect would be similar to flute celestes and would keep Saariaho's compositional intention.

These are a few examples of adapting a proposed registration by creating a similar effect or timbre as suggested by the score. The topic of registration has received much attention by organist pedagogues and scholars. Please refer to Fenner Douglass, Barbara Owen and David Fuller's Grove Dictionary of Music article on "Registration" for an extensive bibliography on the topic. ${ }^{101}$

\footnotetext{
${ }^{100}$ Barbara Owen, "Tremulant," Grove Music Online, 2001; Accessed 3 July 2020, https://www-oxfordmusiconlinecom.www.libproxy.wvu.edu/grovemusic/view/10.1093/gmo/9781561592630.001.0001/o mo-9781561592630-e-0000049736.

${ }^{101}$ Fenner Douglass, Barbara Owen, and David Fuller, "Registration," Grove Music Online, 2001; Accessed 20 June 2020, https://www-oxfordmusiconlinecom.www.libproxy.wvu.edu/grovemusic/view/10.1093/gmo/9781561592630.001.0001/o mo-9781561592630-e-0000047609.
} 


\section{THE STOPS OF THE GRAND ORGUE PIERRE- BÉIQUE}

Grand Choeur

(en pieds)

Montre 16

Montre 8

Bourdon 8

Flûte harmonique 8

Prestant 4

Flûte 4

Quinte 2 2/3

Doublette 2

Cornet V 8

Grand plein jeu III-V

Fourniture IV-V

Cymbale III

Bombarde 16

Trompette 8

Grand Choeur

Expressif

Bourdon * 16

Diapason ** 8

Violon 8

Voix céleste 8

Bourdon 8

Grand nazard * $51 / 3$

Octave $* * 4$

Violon * 4

Flûte ouverte * 4

Grande tierce * $31 / 5$

Nazard * 2 2/3

Septième * 2 2/7

Quarte de nazard * 2

Tierce $13 / 5$

Piccolo 1

Mixture ** III-V

Clarinette $* 8$

Trémolo

Cor français ** 8

Trombone 16

Trompette harmonique 8

Clairon harmonique 4
Cloches

* Extension vers le grave

pour jeux expressifs à la

Pédale

** Jeux haute pression, en

boîte expressive séparée

Positif

Expressif

Quintaton 16

Principal 8

Bourdon 8

Flûte harmonique 8

Prestant 4

Flûte à cheminée 4

Nazard 2 2/3

Doublette 2

Tierce $13 / 5$

Larigot $11 / 3$

Plein Jeu IV

Cymbale IV

Basson 16

Trompette 8

Cromorne 8

Clairon 4

Trémolo

Récit

Expressif

Bourdon doux 16

Diapason 8

Cor de nuit 8

Voix éolienne 8

Flûte traversière 8

Viole de gambe 8

Voix céleste 8

Octave 4

Flûte octaviante 4

Nazard harmonique 2 2/3

Octavin 2

Cornet V 8

Fourniture III

Cymbale III

Bombarde 16

Trompette harmonique 8
Hautbois 8

Voix humaine 8

Clairon harmonique 4

Trémolo

Pédale

Montre 32

Soubasse * 32

Contrebasse 16

Montre 16

Montre - Grand Orgue 16

Soubasse 16

Bourdon * 16

Grande quinte * 10 2/3

Octave 8

Violoncelle $* 8$

Flûte * 8

Bourdon 8

Grande tierce * $62 / 5$

Quinte * $51 / 3$

Grande septième * 4 4/7

Octave 4

Flûte * 4

Contre-bombarde 32

Bombarde 16

Basson 16

Clarinette * 16

Trompette 8

Clairon 4

* Expressif, extension du

Grand Choeur

Chamades

Division flottante +

Dessus de Bombarde 16

Basse de trompette 8

Dessus de trompette 8

2e trompette - du 168

3e trompette - du 48

Basse de Clairon 4

Dessus de Clairon 4

+ En double division

flottante

à toutes les divisions

Example 51 - Stop list from the organ at Maison Symphonique de Montréal Hall ${ }^{102}$

102 Orchestre Symphonique de Montréal, "The Organ at Maison Symphonique de Montréal," Accessed June 28 2020. https://www.osm.ca/en/the-organ/. 


\begin{tabular}{|c|c|c|}
\hline \multirow{3}{*}{$\begin{array}{l}\text { WALT DISNEY CONCERT } \\
\text { HALL ORGAN STOP LIST }\end{array}$} & 8' Cor Anglais & 16' Contra Tromba \\
\hline & 4' Clairon & $8^{\prime}$ Tromba \\
\hline & Tremolo & $4^{\prime}$ Tromba Clarion \\
\hline GREAT & $16^{\prime}$ Llamada & Tremblante \\
\hline 32' Violonbasse & 8' Llamada & Chimes \\
\hline $16^{\prime}$ Prestant & 4' Llamada & (Unenclosed) \\
\hline $16^{\prime}$ Violonbasse & $16^{\prime}$ Trompeta de Los Angeles & $8^{\prime}$ Trompeta de Los Angeles \\
\hline $16^{\prime}$ Bourdon & $8^{\prime}$ Trompeta de Los Angeles & (horizontal) \\
\hline $8^{\prime}$ Principal & 16' Positive to Positive & 16' Llamada (ext.) \\
\hline 8' Diapason à Pavilon & Positive Unison off & $8^{\prime}$ Llamada (horizontal Tuba) \\
\hline $8^{\prime}$ Violoncelle & $4^{\prime} \quad$ Positive to Positive & 4' Llamada (ext.) \\
\hline 8' Flûte harmonique & Harp & Llamadas transfer to Great \\
\hline $8^{\prime}$ Chimney Flute & Celesta & Sostenuto \\
\hline $8^{\prime}$ Bourdon & Sostenuto & Cymbelstern \\
\hline 5-1/3' Grand Nasard & & Campanitas \\
\hline $4^{\prime}$ Octave & SWELL (enclosed) & Pajaritos (4 pipes) \\
\hline $4^{\prime} \quad$ Spire Flute & $16^{\prime}$ Bourdon & \\
\hline 3-1/5' Grande Tierce & 8' Diapason & PEDAL \\
\hline 2-2/3' Octave Quinte & $8^{\prime}$ Flûte traversière & $32^{\prime}$ Flûte \\
\hline 2' Super Octave & $8^{\prime}$ Bourdon & $32^{\prime}$ Violonbasse \\
\hline III Grande Fourniture & $8^{\prime}$ Viole de Gambe & $32^{\prime}$ Bourdon \\
\hline VIII Mixture & $8^{\prime}$ Voix céleste $(\mathrm{CC})$ & $16^{\prime}$ Flûte (ext.) \\
\hline IV Cymbale & 8 'Dulciane doux & $16^{\prime}$ Prestant (Gr.) \\
\hline & $8^{\prime}$ Voix Angelique (t.c) & $16^{\prime}$ Violonbasse (Gr.) \\
\hline $32^{\prime}$ Contre Basson (ext. 16' ) & 4' Principal & $16^{\prime}$ Subbass \\
\hline $\begin{array}{l}16^{\prime} \text { Basson } \\
\text { lext. } 10\end{array}$ & 4' Flûte octaviante & $16^{\prime}$ Bourdon (Sw.) \\
\hline $\begin{array}{l}\text { 16' Basson } \\
8^{\prime} \text { Basson }\end{array}$ & $2-2 / 3^{\prime} \quad$ Nasard & $10-2 / 3^{\prime}$ Grosse Quinte \\
\hline $\begin{array}{l}8^{\prime} \text { Basson } \\
4^{\prime} \quad \text { Basson }\end{array}$ & $2^{\prime}$ Octavin & $8^{\prime}$ Octave \\
\hline & $1-3 / 5^{\prime}$ Tierce & $8^{\prime}$ Flûte (ext.) \\
\hline $\begin{array}{l}8^{\prime} \text { Trompeta de Los Angeles } \\
16^{\prime} \text { Great to Great }\end{array}$ & 1' Piccolo & $8^{\prime}$ Violoncelle (Gr.) \\
\hline $\begin{array}{l}16^{\prime} \text { Great to Great } \\
\text { Tremolo }\end{array}$ & III-V Plein jeu harmonique (2- & $8^{\prime}$ Bourdon (ext. Subbass) \\
\hline $\begin{array}{l}\text { Tremolo } \\
\text { Sostenuto }\end{array}$ & $\left.2 / 3^{\prime}\right)$ & $4^{\prime}$ Super Octave \\
\hline & $16^{\prime}$ Bombarde & 4' Flûte (ext.) \\
\hline POSITIVE (enclosed) & $8^{\prime}$ Trompette & V Mixture (5-1/3' ) \\
\hline $16^{\prime}$ Quintaton & $8^{\prime}$ Hautbois & 64' Contre Basson \\
\hline $8^{\prime} \quad$ Principal & $8^{\prime}$ Voix humaine & $32^{\prime}$ Contre Bombarde \\
\hline $8^{\prime}$ Unda Maris (CC) & 4' Clairon & 32' Contre Basson (Gr.) \\
\hline 8' Gambe & Fast Tremulant & $16^{\prime}$ Grande Bombarde (ext.) \\
\hline $8^{\prime}$ Flûte harmonique & Slow Tremulant & 16’ Llamada (L1.) \\
\hline 8' Gedackt & 8' Trompeta de Los Angeles & $16^{\prime}$ Contra Tromba (L1.) \\
\hline 4' Octave & $8^{\prime} \quad$ Llamada & 16' Basson (Gr.) \\
\hline 4' Hohlflöte & $16^{\prime}$ Swell to Swell & 8' Trompeta de Los Angeles \\
\hline $2-2 / 3^{\prime}$ Nasard & Swell Unison off & (Gr.) \\
\hline $2^{\prime}$ Super Octave & 4' Swell to Swell & 8' Llamada (L1.) \\
\hline $2^{\prime}$ Waldflöte & Sostenuto & $8^{\prime}$ Basson (Gr.) \\
\hline $1-3 / 5^{\prime}$ Tierce & & 4' Trompeta de Los Angeles \\
\hline $1-1 / 3^{\prime}$ Larigot & LLAMARADA (Enclosed) & (Gr.) \\
\hline IV Mixture (1-1/3' $)$ & $8^{\prime}$ Flautado grandiso & 4' Llamada (Ll.) \\
\hline $8^{\prime}$ Trompette & 4' Octavareal & Pedal Chimes \\
\hline 8 rompette & V Compuestas & \\
\hline 8 Cromorne & V Lleno fuerte & \\
\hline
\end{tabular}

\section{Example 52 - Stop list from the organ at the Walt Disney Concert Hall ${ }^{103}$}

${ }^{103}$ Jennifer A. Zobelein, A Forest of Pipes: The Story of the Walt Disney Concert Hall Organ, online supplement, Stoplist, (Self-published, Createspace, 2014.) 


\section{Bibliography}

Adlington, Robert. 2003. "Moving beyond motion: Metaphors for changing sound." Journal Of The Royal Musical Association 128, no. 2 (2003): 297-318.

Allen, John Clay. "An Analysis of Du cristal...à la Fumée by Kaija Saariaho and Axiom Unearthed, Original Composition." Master's Thesis, University of North Texas, 2015.

Anderson, Julian. "A Provisional History of Spectral Music." Contemporary Music Review 19, no. 2 (2000): 7-22.

Anderson, Julian. "Spectral music." Grove Music Online. 4 May. 2018. http://www.oxfordmusiconline.com/grovemusic/view/10.1093/gmo/97815615926 30.001.0001/omo-9781561592630-e-0000050982.

Anderson, Julian "Seductive Solitary. Julian Anderson Introduces the Work of Kaija Saariaho." The Musical Times 133, no. 1798 (1992): 616-619.

Anderson, Warren, Thomas J. Mathiesen, Susan Boynton, Tom R. Ward, John Caldwell, Nicholas Temperley, and Harry Eskew. "Hymn." Grove Music Online. 2001; Accessed 23 Apr. 2020. https://www-oxfordmusiconlinecom.www.libproxy.wvu.edu/grovemusic/view/10.1093/gmo/9781561592630.001. 0001/omo-9781561592630-e-0000013648.

Barone, Michael. "Selected Repertoire for Organ and Orchestra." Pipedreams. June 2011. https://pipedreams.publicradio.org/pdf/organ_orchestra_repertoire.pdf.

Besharse, Kari. "The role of texture in French spectral music." Doctoral dissertation, Univeristy of Illoise at Urbana-Chapagne, 2009.

Beyer, Anders. "Till death us do part: A portrait of the Finnish composer Kaija Saariaho." Nordic Sounds 1 (2000): 3-9.

Brech, Martha. "Kaija Saariaho's diptych Du cristal and ... à la Fumée: An analytical approach." In Topics-texts-tensions: Essays in music theory on Paavo Heininen, Joonas Kokkonen, Magnus Lindberg, Usko Meriläinen, Einojuhani Rautavaara, Kaija Saariaho \& Aulis Sallinen. Magdeburg, Germany: Otto-vonGuerike-Universität, 1999: 26-50.

Campbell, Murray. "Inharmonicity." Grove Music Online. 2001; Accessed 11 Aug. 2020. https://www-oxfordmusiconlinecom.www.libproxy.wvu.edu/grovemusic/view/10.1093/gmo/9781561592630.001. 0001/omo-9781561592630-e-0000013801. 
Campbell, Murray. "Partial." Grove Music Online. 2001; Accessed 11 Aug. 2020. https://www-oxfordmusiconline-

com.www.libproxy.wvu.edu/grovemusic/view/10.1093/gmo/9781561592630.001. 0001/omo-9781561592630-e-0000020975.

Clark, Timothy. "Shelley after Deconstruction: The Poet of Anachronism." In Evaluating Shelley, edited by Timothy Clark and Jerrold E. Hogle. Edinburgh: Edinburgh University Press, 1996: 91-108. Accessed August 11, 2020. doi:10.3366/j.ctvxcrnhk.11

Cone, Edward T. "Thinking (About) Music." Proceedings of the American Philosophical Society 148, no. 4 (1994): 469-475.

Davis, Roger E. The Organists' Manual. New York: W. W. Norton \& Company, 1985.

Douglass, Fenner, Barbara Owen, and David Fuller. "Registration." Grove Music Online. 2001; Accessed 20 June 2020. https://www-oxfordmusiconlinecom.www.libproxy.wvu.edu/grovemusic/view/10.1093/gmo/9781561592630.001. 0001/omo-9781561592630-e-0000047609.

"Esa-Pekka Salonen, Kaija Saariaho and Olivier Latry introduce Saariaho's Maan varjot." Philharmonia Orchestra. Youtube video, 08:06. June 12, 2014. https://www.youtube.com/watch?v=p4lfQy-ImhY

Everett, Yayoi Uno. "Reconfiguring Myth and Narrative in Contemporary Opera: Osvaldo Golijov, Kaija Saariaho, John Adams, and Tan Dun." Bloomington, Indiana: Indiana University Press, 2015.

Facciuto, Neal. "Kaija Saariaho's L'Amour De Loin: Axes and Synthesis." Doctoral dissertation, University of Florida, 2015.

Fineberg, Joshua. "Guide to the basic concepts and techniques of spectral music." Contemporary Music Review 19, no. 2 (2000): 81-113.

Fineberg, Joshua. "Spectral Music." Contemporary Music Review 19, no. 2 (2000): 1-5.

Fletcher, Harvey. "Normal Vibration Frequencies of a Stiff Piano String." The Journal of the Acoustical Society of America Vol. 36, No. 1 (Jan 1964): 203-209.

Gleason, Harold. Method of Organ Playing, Eighth Edition. Upper Saddle River, New Jersey: Prentice Hall, 1996.

Greated, Clive. "Frequency." Grove Music Online. 2001; Accessed 11 Aug. 2020. https://www-oxfordmusiconlinecom.www.libproxy.wvu.edu/grovemusic/view/10.1093/gmo/9781561592630.001. 0001/omo-9781561592630-e-0000010215. 
Griffiths, Paul. "Serialism." Grove Music Online. 2001; Accessed 30 June 2020. https://www-oxfordmusiconlinecom.www.libproxy.wvu.edu/grovemusic/view/10.1093/gmo/9781561592630.001. 0001/omo-9781561592630-e-0000025459.

Headlam, Dave, Robert Hasegawa, Paul Lansky, and George Perle. "Twelve-note composition." Grove Music Online. 2001; Accessed 3 July 2020. https://wwwoxfordmusiconlinecom.www.libproxy.wvu.edu/grovemusic/view/10.1093/gmo/9781561592630.001. 0001/omo-9781561592630-e-0000044582.

Howell, Tim, Jon Hargreaves, and Michael D. Rofe. Kaija Saariaho: Visions, narratives, dialogues. Farnham: Ashgate, 2011.

Iitti, Sanna. "Kaija Saariaho: Stylistic development and artistic principles." The International Alliance for Women in Music Journal 7, no. 3 (2001): 17-20.

Jackson, H. J. "The 'AI' in 'ADONAIS'." The Review of English Studies 62, no. 257 (2011): 777-84. Accessed August 11, 2020. www.jstor.org/stable/41410065.

Kern, Friedrich Heinrich. "An Exploration of Compositional Technique in the Operas of Kaaija Saariaho and Christian Jost." Doctoral dissertation, New York University, 2016.

Korhonen, Kimmo, and Risto Nieminen. "Saariaho, Kaija." Grove Music Online. 4 May. 2018.

http://www.oxfordmusiconline.com/grovemusic/view/10.1093/gmo/97815615926 30.001.0001/omo-9781561592630-e-0000045895.

"Les secrets du Grand Orgue Pierre-Béique / Orchestre symphonique de Montréal OSM." Orchestre symphonique de Montréal. Youtube video, 4:07. February 19. 2015. https://www.youtube.com/watch?v=YFYukHb5NqU

Lieder, Colby. Digital Audio Workstation. New York: McGraw Hill, 2004.

Marshall, Robert L., and Robin A. Leaver. "Chorale." Grove Music Online. 2001; Accessed $23 \quad$ Apr. $2020 . \quad$ https://www-oxfordmusiconlinecom.www.libproxy.wvu.edu/grovemusic/view/10.1093/gmo/9781561592630.001. 0001/omo-9781561592630-e-0000005652.

Moisala, Pirkko. "Kaija Saariaho." Urbana and Chicago: University of Illinois Press, 2009. 
Moisala, Pirkko. "Reflections on an Ethnomusicological Study of a Contemporary Western Art Music Composer." Ethnomusicology Forum 20, no. 3 (2011): 443451.

Murray, Michael. Marcel Dupré: The Work of a Master Organist. Boston: Northeastern University Press, 1985.

Nieminen, Risto. "Kaija Saariaho: 'At the moment the computer and I belong together."' Finish Music Quarterly 3/4 (1988). https://fmq.fi/articles/kaija-saariaho-8220-atthe-moment-the-computer-and-i-belong-together

Orchestre Symphonique de Montréal. "The Organ at Maison Symphonique de Montréal." Accessed June 28 2020. https://www.osm.ca/en/the-organ/

Owen, Barbara. "Tremulant." Grove Music Online. 2001; Accessed 3 July 2020. https://www-oxfordmusiconline-

com.www.libproxy.wvu.edu/grovemusic/view/10.1093/gmo/9781561592630.001. 0001/omo-9781561592630-e-0000049736.

Owen, Barbara, Peter Williams, and Stephen Bicknell. "Organ." Grove Music Online. 2001; Accessed 30 June 2020. https://www-oxfordmusiconlinecom.www.libproxy.wvu.edu/grovemusic/view/10.1093/gmo/9781561592630.001. 0001/omo-9781561592630-e-0000044010.

Parncutt, Richard, and Hans Strasburger. "Applying Psychoacoustics in Composition: "Harmonic" Progressions of "Nonharmonic" Sonorities." Perspectives of New Music 32, no. 2 (1994): 88-129.

Place des Arts. "Maison symphonique." Accessed June 282020. https://placedesarts.com/en/produce-event/rent-venue/maison-symphonique

Poetry Foundation. "Adonais: An Elegy on the Death of John Keats." Accessed 6 November 2019. https://www.poetryfoundation.org/poems/45112/adonais-anelegy-on-the-death-of-john-keats

Pousset, Damien, Joshua Fineberg and Ronan Hyacinthe. "The Works of Kaija Saariaho, Philippe Hurel and Marc-Andre Dalbavie--Stile Concertato, Stile Concitato, Stile Rappresentativo." Contemporary Music Review 19, no. 3 (2000): 67-110.

Prickett, Amy Lynn. "Kaija Saariaho's Path to the Met: The Merger of Convential and Unconventional Musical Devices in "L'Amour De Loin"." Doctoral dissertation, The University of Alabama, 2017. 
Reid, L. C. "Composing Timbre Spaces, Composing Timbre in Space: An Exploration of the Possibilities of Multidimensional Timbre Representations and their Compositional Applications." Doctoral dissertation, Stanford University, California, 2013.

Roeder, John. "Pitch class." Grove Music Online. 2001; Accessed 23 June 2020. https://www-oxfordmusiconlinecom.www.libproxy.wvu.edu/grovemusic/view/10.1093/gmo/9781561592630.001. 0001/omo-9781561592630-e-0000021855.

Roeder, John. "Set (ii)." Grove Music Online. 2001; Accessed 23 June 2020. https://www-oxfordmusiconlinecom.www.libproxy.wvu.edu/grovemusic/view/10.1093/gmo/9781561592630.001. 0001/omo-9781561592630-e-0000025512.

Rose, François. "Introduction to the Pitch Organization of French Spectral Music." Perspectives of New Music 34, no. 2 (1996): 6-39.

Saariaho, Kaija. "Kaija Saariaho.” Kaija Saariaho. 2015. http://saariaho.org

Saariaho, Kaija. "Maan Varjot (Earth's Shadows)." Wise Music Classical. Accessed March 7, 2020. https://www.wisemusicclassical.com/work/48887/.

Saariaho, Kaija. "Timbre and harmony: Interpolations of timbral structures." Contemporary Music Review 2, no.1 (1987): 93-133.

Saariaho, Kaija and et al. "Kaija Saariho." Music \& Literature, No. 5 (2014): 1-146.

Schulslaper, Robert. "Notes on Light: A Conversation with Kaija Saariaho." Fanfare: The Magazine For Serious Record Collectors 32, no. 2 (2008): 50-60.

Siegel, Karen J. "Timbral Transformations in Kaija Saariaho's from the Grammar of Dreams." Doctoral dissertation, City University of New York, 2014.

Singleton, Philip. "Spectralism Today: A Survey of the Consequences for Contemporary Composition of the French Spectral School of the 1970s and 1980s." PhD thesis, University of Surrey (United Kingdom), 2016.

Sirota, Nadia. "Kaija Saariaho: Ears Open." Produced by WNYC. Meet the Composer. July 30, 2015. Podcast, 1:04:00. Accessed May 5, 2018. https://www.npr.org/podcasts/528124256/meet-the-composer.

Taylor, Charles, and Murray Campbell. "Sound." Grove Music Online. 2001; Accessed $162020 . \quad$ Jul. 202 https://www-oxfordmusiconlinecom.www.libproxy.wvu.edu/grovemusic/view/10.1093/gmo/9781561592630.001. 0001/omo-9781561592630-e-0000026289. 
Thistlethwaite, Nicolas, and Geoffrey Webber, ed. The Cambridge Companion to the Organ. Cambridge: Cambridge University Press: 2006.

Tidey, Jon. "ReaVerbate Tutorial and Free presets." Reaper Blog, March 10, 2016. https://reaperblog.net/2016/03/reaverbate-tutorial-and-free-presets/

Tommasini, Anthony. 2016. "Review: A Newly Relevant 'L'Amour de Loin' at the Met." New York Times, Dec 2016. https://www.nytimes.com/2016/12/02/arts/music/review-met-opera-amour-deloin-kaija-saariaho.html

Viitanen, Harri. Liner notes to Firmamentum. Harri Viitanen. Grammofon AB BIS. CD887. CD. 1997.

"Visite guidée du Grand Orgue Pierre-Beique de l'Orchestre symphonique de Montréal." Orchestre symphonique de Montréal. Youtube video, 18:28. February 21, 2018. https://www.youtube.com/watch?v=bH01irZrSSU

White, Glenn D., and Gary J. Louie. The Audio Dictionary: Third Edition, Revised and Expanded. Seattle; London: University of Washington Press, 2005.

Young, R.W. "Terminology of Logarithmic Frequency Units." The Journal of the Acoustical Socioety of America, 11 (1939): 166.

Zobelein, Jennifer A. A Forest of Pipes: The Story of the Walt Disney Concert Hall Organ. Self-published, Createspace, 2014. 